\title{
THOUGHT AND TECHNIQUE IN THE POETRY \\ OF OKOT P'BITEK
}

\section{A THESIS}

SUBMITTED TO THE FACULTY OF ATLANTA UNIVERSITY IN PARTIAL FULFILIMENT OF THE REQUIREMENTS FOR THE DEGREE OF MASTER OF ARTS

BY

MONICA NALYAKA WANAMBISI

DEPARTMENT OF ENGLISH

ATLANTA, GEORGIA

DECEMBER 1981

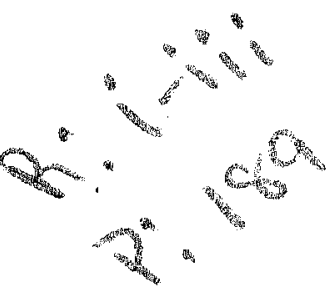


ACKNOWLEDGMENTS

I gratefully extend my profound gratitude and sincere appreciation to my advisor, Dr. David Dorsey, Professor of English, Atlanta University, for his patience, valuable time, constructive criticisms and for his many other valuable suggestions, without whose assistance and unfailing encouragement, this thesis could not have materialized. I also extend my deepest gratitude to Mrs. Lucy Grigsby, the Chairperson of the English Department, Atlanta University, for her efforts in this thesis. Further thanks go to my typist, Mrs. Mary Ellen James, for giving generously of her valuable time to type this thesis. Last, but not least, I extend my sincere appreciation to the Atlanta University for granting me a scholarship.

M. N. W. 
TABLE OF CONTENTS

ACKNOWLEDGMENTS

ii

Chapter

I. INTRODUCTION

Life of Okot p'Bitek

Brief Description of His Literary Work

okot's contribution to Intellectual

Life of East Africa

outline of Issues and Scope for This Study

II. THEMES IN SONG OF LAWINO AND SONG OF OCOL . • • 26

III. THEMES IN SONG OF A PRISONER AND SONG OF MALAYA .................. 91

IV. TECHNIQUES IN THE SONGS . . . . . . . . . 126

V. SUMMARY AND CONCLUSTON . . . . . . . . . 173

BIBLIOGRAPHY ................ 187 
CHAPTER I

INTRODUCTION

\section{Life of Okot p'Bitek}

Okot p'Bitek, novelist, sociologist, philosopher,

theologist, footballer, dancer and above all human being, is internationally recognised as one of Africa's finest poets.

He is the author of original poetry, translations of traditional literature, anthropological studies and other essays. Edward Blishen writes:

The biological facts are themselves remarkable. He was born in 1931 at Gulu in Northern Uganda, and was educated first at Gulu High School and later at one of the most high-flying of Ugandan schools, King's college, Budo. He went on to read education at Bristol, law at Aberystwyth and social anthropology at Oxford: returning to Uganda, he lectured at the University college at Makerere. This academic versatility was matched by considerable athletic skill: among other achievements, he played football for Uganda. A drummer and a dancer, he founded an annual festival of African arts at Gulu. For a while he was Director of the National Cultural centre in Kampala. ${ }^{1}$

$1_{\text {Edward Blishen, Introduction to Song of A Prisoner }}$ by Okot p'Bitek (New York: Joseph Okpaku Publishing Company, Inc., 1971), p. 2 . 
From 1952 to 1954, Okot attended a teacher training course at the Government training college, Mbarara. While at college, he wrote and produced a student opera. When he completed the training, he taught English and Religious Studies for three years at Sir Samuel Baker's School near Gulu. He liked singing and he was the choirmaster at the school. In the 1960's, Okot served both as the director of the Uganda theatre and as a professor at Makerere University. In 1966, Okot became the director of the Uganda Cultural Centre. The Centre had been formerly dominated by expatriates working in the theatre. Okot changed the emphasis of the centre from foreign works to traditional African works. He also introduced and developed a large and successful dance group called "The Heartbeat of Africa." ${ }^{2}$ In 1968, he administered a cultural festival which coincided with Ugandan Independence Day celebrations in October. However, while on a trip from Zambia in relation to this festival, in the same year, he was dismissed from his job as director of the National cultural Centre. He later learned that his dismissal was caused by his criticism of politicians in song of Lawino. Immediately thereafter, Okot took a position in Kisumu in Kenya, where

${ }^{2}$ G. A. Heron, Introduction to Song of Lawino and Song of Ocol, A Combined School Edition by Okot p'Bitek (Nairobi: East African Publishing House, 1972), p. 2 . 
he organised an art festival in the same year. The festival was a large and varied event. It was comprised of drama sessions, children's plays, songs, art exhibitions, and various other aspects of African culture. From 1969-1970, Okot participated in the Writers' Workshop at the University of Iowa, where he wrote much of African Religions in Western Scholarship. He went back to Kenya for some time. Then he returned to the United States in 1971 to be a writer in residence at the University of Iowa. From the University of Iowa, he returned to Kenya where he lectured at the University of Nairobi in both the departments of Sociology and Literature. In 1978 he left for the University of Ife in Nigeria where he taught social anthropology. In 1980 he went back to Uganda. He is currently a lecturer at the University of Makerere, as well as the director of the Uganda Cultural Centre.

From his biography, one finds that Okot p'Bitek has engaged himself actively in various aspects of life including writing. But his writing, the preeminent aspect of his importance, is the subject of this study.

\section{Brief Description of Okot's Literary Work}

In his works, Okot articulates African cultural ways of life such as dancing, singing, story-telling, proverbs 
and myths. He also presents scholarly analyses of these ways of life. He specifically preoccupies himself at length with traditional songs, which are for him a crucial feature of oral literature in Africa. Songs in traditional African society are sung on various occasions. For example, in funerals they are sung to mourn the dead, in weddings and dances they are sung to express joy, and in circumcision ceremonies songs are sung for initiation. Songs also accompany story-telling to add flavor and meaning. Because of the central importance he attributes to song, all of okot's original poems are entitled "songs": Song of Lawino, Song of Ocol, Song of A Prisoner and Song of Malaya.

Okot's first published work is a novel, Lak Tar (1953), written in the Acoli language. It appeared when okot was only twenty-two years old. Lak Tar, when fully translated, means "Are Your Teeth White? If So, Laugh." ${ }^{3}$ At the time Lak Tar was published, Okot was earning a living by playing professional football. Lak Tar

. . tells the story of an Acoli boy whose father dies while he is still very young. A few years later he falls in love with a girl and she agrees to marry him, but he is unable to pay the very high brideprice. His stepfather and his uncles refuse to help

${ }^{3}$ Donald E. Herdeck, African Authors: A Companion to Black African Writing, 1300-1973 (Washington, D. C.: Black Orpheus Press, 1973), p. 339. 
him. The rest of the novel relates the series of misfortunes that befall him when he goes to Kampala to try to earn the money he needs. Despite nearly two years away, he earns only a fraction of the bride-price, and during his return journey he is robbed. The novel ends with his arrival home, miserable and penniless. 4

The plot of Lak Tar reflects Okot's typical preoccupation with traditional life versus Western life. The novel, as observed from the above quotation, relates the misfortunes encountered by the protagonist when he goes to work in the city of Kampala. The modern creation of cities and consequent rural/urban migration of Africans is a product of the Western colonization of Africa. Therefore, one of the important points the novel makes is that as a result of Western influence, young people have to struggle for survival both in the modern world and in the traditional world. In the traditional world, the protagonist of Lak Tar needs to pay bride-price before he can marry a wife. In the modern world of the city, he needs to earn this bride-price. It is in the effort of this struggle to survive in two worlds that the protagonist experiences misfortunes. This same idea of Western influences and their harmful effects on Africans' ways of life is the major concern in Okot's Song of Lawino (1966).

4 Heron, Introduction to Song of Lawino and Song of Ocol, p. 8 . 
In 1971, Okot published two books on African religions, namely, African Religions in Western Scholarship

(1971) and Religion of the central Luo (1971). The former is an attack on the Western scholarly treatment of African religions, both in the past and in the present. It is also a bitter attack on Western negative attitudes towards Africans themselves. Okot says:

I first met a number of Western scholars at oxford University in 1960. During the very first lecture in the institute of social anthropology, the teacher kept referring to Africans or non-Western peoples as barbarians, savages, primitives, tribes, etc. I protested; but to no avail. All the professors and lecturers in the institute, and those who came from outside to read papers, spoke the same insulting language. 5

Hence, because of the negative attitudes of Western peoples to Africans, Okot's intention in African Religions in Western Scholarship is to urge African scholars

- . to expose and destroy all false ideas about African peoples and culture that have been perpetuated by Western scholarship. Vague terms such as Tribe, Folk, Non-literate or even innocent looking ones such as Developing, etc. must be subjected to critical analysis and thrown out or redefined to suit African interests. Second, the African scholar must endeavour to present the institutions of African peoples as they really are. 6

${ }^{5}$ okot p'Bitek, African Religions in western Scholarship (Nairobi: East African Literature Bureau, 1971), p. vii.

$$
{ }^{6} \text { Ibia., p. } 7 .
$$


It is with this view that okot attempts to instill an appreciation of the positive elements in traditional African thought, and to expose the falsity of Western society's claim to be better or more functional than African society. Hence African Religions in Western Scholarship is strongly critical of social anthropology for having been used by Western societies to justify colonialism, imperialism, and slavery. Okot reasons that:

Although social anthropology has been described as the study of man and his works, in western scholarship it has been, until very recently, the study of the so called 'tribal' peoples, and has shown very little interest in Western industrialised societies. 7

What makes this prejudice worse is that:

-. In general usage, the word tribe is taken to denote a primary aggregate of peoples living in a primitive or barbaric condition under a chief. 8

Owing to the distortion of the African image, Okot urges that:

The African scholar is called upon to participate fully in nation building, and he can best do this by presenting the Truth about Africa. 9

One further notes that okot believes that profound understanding of African religion is essential for proper social reform in Africa. Hence, African scholars should study the African

$$
7 \text { Ibid., p. 9. } 8 \text { Ibid., p. } 10 . \quad 9_{\text {Ibid.. p. } 7 .}
$$


religions in depth, and present the reality about them.

It follows that if the leaders sincerely believe that the social reconstruction in Africa should be based on the African worldview, their religions must be studied and presented as accurately as possible, so as to discover the African worldview. Christian sex ethics, its other-worldliness, and its preoccupations with sin are three important areas which African intellectuals and leaders can explore, because, here Christianity contrasts vividly with African religions.10

It is not a surprise, then, that okot rejects the missionary's introduction of such practices as boarding or mission schools which separate the female sex from the male sex to avoid social contact. ${ }^{11}$

More importantly, due to the distortion of the African image through Western views in the study of social anthropology, okot does not approve teaching social anthropology in African universities and colleges. With its Western point of view, it would teach African students negative attitudes about themselves, which in turn may lead to self-hatred. This view can also be observed in the songs. For example, in Song of Lawino and song of Ocol, Lawino, an ordinary girl from the village, is married to Ocol, who, after acquiring Western education, rejects his own original

${ }^{10}$ Ibid., p. 113 .

${ }^{11}$ For a detailed discussion of this matter, see Ibid.. pp. 113-117. 
African values. Ocol is ashamed of his own continent, Africa, saying:

What is Africa

To me?

Blackness

Deep, deep fathomless

Darkness. 12

In African Religions in Western Scholarship, then, Okot aims to examine how the Western scholars have divided "the world into two, one their own, civilized, great, developed: the other, the non-Western peoples, uncivilized, simple, undeveloped. One is modern, the other tribal."13 This leads okot to analyse western society and to expose its false claims to be better than African societies as discussed in Song of Lawino.

In Religion of the Central Luo (1971), Okot studied religions of the Luo, his own people. In this book, he makes use of oral literature, especially singing. His use of singing deserves detailed examples. Okot shows how singing accompanies the ancestoral worship of the Acoli. When an elderly man dies, he joins the living dead to intercede for

12 okot p'Bitek, song of Lawino and song of Ocol, A Combined School Edition (Nairobi: East African Publishing House, 1972), p. 206. p. 215 .

${ }^{13}$ p'Bitek, African Religions in Western Scholarship. 
his people. Therefore, the clan members build a shrine in the home of the deceased. Cows, goats, chickens are slaughtered and there is a feast. People eat the meat and drink the beer at the shrine. After that, the clan sings to pay tribute to the deceased and also to ask him to intercede for them. Okot quotes a song which accompanies such a worship; a leader leads the clansmen in the song.

Leader: Wan tin Watedo Wora

Tin Wamiyo ive remo

Wamiye gweno Ki Kongo

Kom dano obed ma yot

People: Kom dano obed ma yot

Leader: Nguo otoo

People: Otoo, otoo, otoo

Leader: Tony Obed ma bit

People: obed ma bit, bit, bit, etc.

Leader: Today we have cooked [a feast

for] my father

Today we have given him chicken

and beer

Let the people have good health.

People: Let the people have good health.

Leader: Lions let them die.

People: Let them die, die, die

Leader: The spears let them be sharp, sharp, sharp, etc. 14

${ }^{14}$ Okot p'Bitek, Religion of the Central Luo (Nairobi: East African Literature Bureau, 1971), pp. 94-99. 
Here Okot is demonstrating the elements of songs in oral literature with its social and religious didacticism, andwith its poetic form. By his discussion of this and similar examples, okot presents the rituals and worldview of the Luo. In the two books on African religions, Okot first attempts to indicate the error of Western scholars' approach to African religions. Secondly, he endeavours to portray accurately the worship of African religions, specifically with aspects of ancestral worship among the Luo. As all of his books show, Okot believes that thorough understanding of Luo oral literature is required for correct understanding of the religion and values of his culture. This focus on oral literature is not coincidental. As Heron has said:

Oral literature shaped Okot's imagination in his infancy and has also been at the centre of his work activities for much of his adult life. 15

Okot's study of oral literature is most directly and fully illustrated in two later books, Horn of My Love and Hare and Hornbill.

Horn of My Love (1974) is a translation of poetry of the Acoli of northern Uganda. The book offers good examples of oral literature of the Luo people as a current expression

${ }^{15} \mathrm{G}$. A. Heron, The Poetry of Okot p'Bitek (London: Cox and Wyman Press, 1976), p. 5. 
of traditions from time immemorial. The first chapters of the book describe the dances of the African people and the songs that were sung during those dances, and on what occasions the songs and dances took place. The chapters that follow consist of Acoli songs and Okot's English translations of the songs. The significance of this book lies firstly in its recording and therefore preservation of oral literature. As Tim Pickford, in his review of Horn of My Love, writes:

Okot's presentation of more than one hundred Acoli poems in both the vernacular and an English translation adds to the evergrowing numbers of collections of the previously unrecorded oral 'literatures' of Africa; it brings to the notice of his own people, as well as to that of the English speaking world, the presence of various genres of song and dance whose words convey tribal lore, social and personal experiences, desires, regrets and challenges; indeed, whose words express the various everyday preoccupations and the unique occurrences of the people. 16

Horn of My Love is important in part because of its insight into oral traditions of the Acoli. In 1964 Okot wrote a thesis in social anthropology entitled oral Literature and Its Social Background Among the Acoli and Lang'o which discusses Acoli songs, religious ideas, myths and proverbs, and their function in social life. One of the songs

${ }^{16}$ Tim Pickford, "Horn of My Love: A Review," in African Literatures: Some Notes, ed. Jan Knappert (Hamilton, New Zealand: Outrigger Publishers, 1975), p. 6 . 
recorded in this thesis accuses a soldier of failing to take care of his wife, because the soldier is "off to shoot (fight) Hitler." 17 The emphasis on traditional family and on the traditional duties of husbands is echoed here. Traditionally, a husband is supposed to take care of his wife both materially and morally; he should protect his wife. But again, Okot is saying that as a result of the coming of white people to East Africa, and the second World War, many Africans were employed as soldiers to go and fight in lands unknown, leaving their wives uncared for. The traditional values as echoed here are discussed in Song of Lawino and Song of Ocol. Like the soldier in this song, Ocol in the longer "songs" virtually abandons $h$ is wife because of the influence of Western education.

Hare and Hornbill (1978) is yet another of Okot's skillfully told selections of oral literature. It is a good example of many "folktales" which were told by Africans as their only form of literature before they knew how to write and record their literature. For example, in Kenya youths often slept at their grandparents' house, where their grandparents would tell them tales at the evening fire before they

${ }^{17}$ Okot p'Bitek, Oral Literature and Its Social Background Among the Acoli and Lang'O (B. Litt thesis, University of Oxford, 1964), p. 310 . 
went to sleep. Such "folktales" were passed on from generation to generation, and they served two basic purposes of literature: entertainment and didacticism, including principles of ethics, religion and philosophy.

From the above analysis, one finds that okot has dealt at length with oral literature in both his scholarly and literary works. In discussion of our focal texts, his songs, one will also find that the influence of oral literature is critical. By his pioneering emphasis in his poetry on the oral literature, the real literature of the African people, Okot has contributed significantly to East African poetic style. Oral literature had been ignored by African writers owing to European influence. Again as G. A. Heron notes :

Sadly, the written literature of the African nations has been clearly separated in many people's minds from the oral literary heritage that is present in every African community. Comparisons have more often been made between African poems and European poems than between African poems and traditional songs.

Okot p'Bitek compels us to make comparisons between his poems and traditional songs. The title 'Song of - .' that he has given to all his poems suggests the comparison. He used many features borrowed from traditional songs in the writing of Song of Lawino. Partly because of the familiarity of these features to all Africans, song of Lawino has become one of the most successful African literary works.18

18 Heron, Introduction to Song of Lawino and Ocol, p. 6. 
Besides his preoccupation with oral literature, Okot p'Bitek has written other articles and essays which are critical of social, economic, political ills as practiced by Africans themselves. This political subject is another major link between Okot's four songs and his other works. One such article is "Indigenous Ills" in Transition: A Journal of the Arts and culture and Society. In "Indigenous Ills" Okot is critical of the political system:

- . whereby independence means the replacement of foreign rule by native dictatorship. What does equality mean in newly independent African states?19

Okot's criticism of capitalism is also clear in "Indigenous Ills." He criticizes the African governments not only for their "dictatorship" and "discrimination policy" but also for their capitalism.

The students in our university are not revolutionary. They are committed and conservative. They have vested interests. They look forward to graduation, the circumcision ceremony before joining the 'big car' tribesmen. Our university and schools are nests in which black exploiters are hatched and bred, at the expense of taxpayers, or perhaps heartpayers. 20

Okot's concern with political ills in African governments is echoed in song of Ocol and Song of Prisoner. In Song of

${ }^{19}$ Okot p'Bitek, "Indigenous Ills," Transition: A Journal of the Arts, Culture and Society $7: 32$ (August/ September 1967): 47 .

20 Ibid. 
Ocol, he questions:

$$
\begin{aligned}
& \text { What did you reap } \\
& \text { When Uhuru ripened } \\
& \text { And was harvested?21 }
\end{aligned}
$$

"Uhuru" is a Swahili word meaning freedom or independence. At the acquisition of "Uhuru," many Africans were happy, anticipating a trouble-free society.

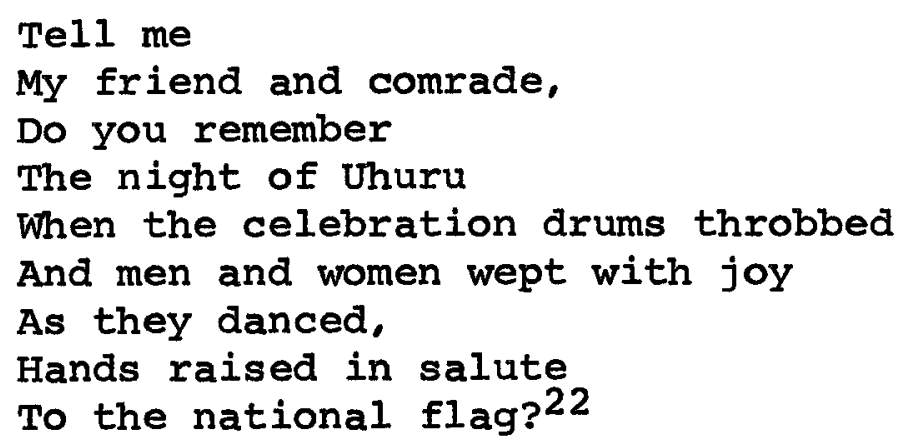

However, irrespective of their celebrations, the African people have had problems even under their rulers who often do not seem to care about their problems. For example, Ocol speaking as a president says:

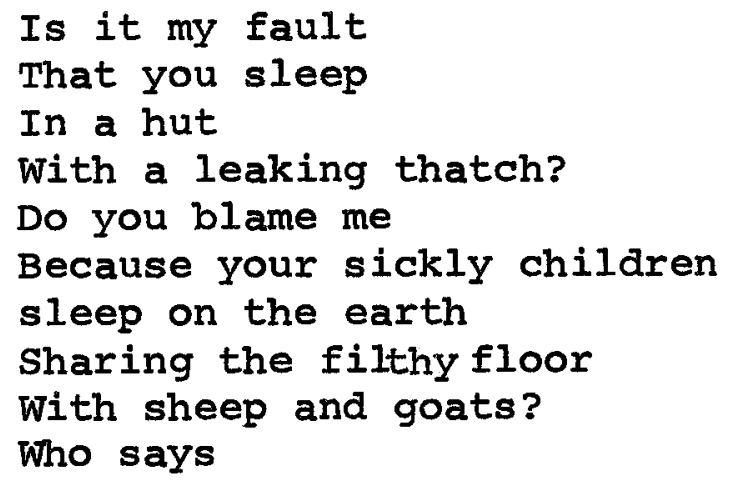


I am responsible

For the poverty of the peasantry?

Am I the cause of unemployment

And landlessness? ${ }^{23}$

A similar case occurs in Song of A Prisoner, whereby the protagonist, a prisoner, fought for "Uhuru" and yet he is poor. His wife has been seduced by a rich man who has wealth and drives a Mercedes car. The poor man's children suffer from hunger and diseases. Whuru has not helped him.

Ultimately, from the discussion about Okot's literary and scholarly work, one can safely say that Okot's other works have thought similar to the content of his original poetry: Song of Lawino (1966), Song of Ocol (1970), Song of A Prisoner (1971) and Song of Malaya (1971). In conclusion, one can say that:

These widely different books are all united by Okot's concern that the nations of Africa should be built on African not European foundations. 24

In essence, Okot's intention is that Africans should strive for social, political and economic justice. 25

${ }^{23}$ Ibid., p. 235 .

24 Heron, Introduction to Song of Lawino and Ocol. p. 10.

${ }^{25}$ Okot is also the author of a book entitled Africa's Cultural Revolution (Nairobi: Macmillan Books for Africa, 1973); and an article, "Reflect, Reject, Recreate," East African Journal (April 1972), which were not available to me. Both are listed in Heron, The Poetry of Okot p'Bitek, p. 157. 
Okot's Contribution to the Intellectual

Life of East Africa

As we have said, Okot has greatly contributed to the literary and cultural fields of East Africa through his preoccupation with studying East African oral literature, as we observed in both his literary and scholarly works. Significantly he has originated a style in which he uses English merely as a tool to reach his audience without necessarily emulating the Western literary forms of writing. Owing to European influence on the African continent, many Africans write using European forms. Okot is therefore particularly significant because he broke from an East African literary tradition which used European forms. For example, in an interview, Okello Oculi has pointed out how it was inevitable that East African writers use European forms:

Whoever was in charge of the people's education was insisting that we had to learn Shakespeare. We had no choice. We had to pass exams and the exams were about Shakespeare, in the language of Shakespeare's mother tongue. And I think in situations where one has to pass an exam, one has to get good marks . . .26

However, as Oculi suggests, African published writers also did not adopt European styles by mistake or because of their own bad judgment. Most of them had no choice. The

${ }^{26}$ Okello Oculi, Interview in African Writers on African Writing, ed. G. D. Killam (London: Heinemann Educational Books Press, 1973), p. 129. 
publishers were Westerners, and for these African writers to get their manuscripts published, they had to please these publishers by writing in Western forms:

I think most people who would have wanted to make a choice wouldn't have had what they wrote published in the first place, let alone to have the guts to tell anyone that they could be published. It would sound like if a dog walked over to you and said 'You know I've got a manuscript. Would you like to look at it?' You might jump. This is the kind of pressure that they were up against. 27

Okot is unique because instead of emulating Western usage of such elements as imagery or figurative language, he utilizes Acoli images successfully. Okot has a thorough knowledge of his African oral literary tradition. This makes it even easier and more comfortable for him to use African images. G. A. Heron in his introduction to song of Lawino and Ocol comments:

Okot has completely avoided the stock of common images of English literature through his familiarity with the stock of common images of Acoli literature. In the English version, this gives his poem a feeling of freshness for every reader, and a sense of Africanness for African readers. 28

Okot's use of African images in his poems helps him to retain the meaning of the African ideas he is presenting.

27 Ibid.

28 Heron, Introduction to Song of Lawino and Ocol, p. 11 . 
In Okot p'Bitek's poetry, one can see clear links to "traditional" songs, proverbs and other forms of oral literature. By his use of oral literary heritage in his works, Okot has originated a style which has had great influence on many East African literary writers. Many critics have praised okot for his achievement in literary scholarly circles and in other circles. One such critic, Maina Gathungu, makes this comment about Okot's contribution:

Okot is one of the most controversial sons of East Africa both in literary and cultural fields. In local papers, in ordinary conversations, in lecture theatres, overseas and in political circles, Okot has stolen time and space. He has received both criticism and praise from many quarters. The most debated aspect of his work is that he has initiated and originated an East African style which Oculi, Buruga, Akivaga, Standa and Taban are said to have emulated. It is pointless to discuss the merits and demerits of his work here; suffice it to say that okot himself would agree that his was a song and songs happen to be common features of expression in the African world. 29

The critic, Michael R. Ward, also shares the same view when he demonstrates how various writers in East Africa have been encouraged to experiment with new forms, similar to Okot's. Ward demonstrates that one of the achievements of Okot p'Bitek in East Africa's intellectual life has been his success in

29 Maina Cathungu, "Okot p'Bitek: Writer, singer or Culturizer?" in Standpoints on African Literature: A Critical Anthology, ed. Chris Wahjala (Nairobi: East African Literature Bureau, 1973), p. 53. 
experimentation with oral literature.

The success of this kind of experiment demonstrates an East African ability to rescue oral literature from the grip of anthropologists and to combine this attempt with a sensitive handling of the English language tradition. 30

In "Okot p'Bitek and the Rise of East African Writing," Ward observes :

Not all East African writers have been as successful as Okot p'Bitek in translating the experience of African tradition. But the poet ( $p^{\prime}$ Bitek) has had many imitators including Oculi, Buruga and Taban Lo Liyong. Joseph Buruga's The Abandoned Hut, in particular, seems to rely heavily upon okot p'Bitek's achievement. Buruga's poem, in which the hut is a symbol of tradition, deals with the lament of a man whose wife has deserted the tribe. The poet makes a similar selection of detail to that of okot p'Bitek: the strangely shaped water tap, for instance, is chosen for observation as it is in song of Lawino, as is the practice of hair stretching. The passage from The Abandoned Hut which speaks of the Western practice of dancing quietly and in darkness 'like a wizard' reminds us strongly of the passage in song of Lawino:

Dancing without a song Dancing silent like wizards Without respect. drunk. . .

It is important to notice that Okot p'Bitek's work has encouraged people to experiment with the use of form. One of the most interesting, and at the same time baffling of these experiments is Okello Oculi's Prostitute, another lament, but written in the form of a novel. Oculi draws upon the technique of the direct appeal

${ }^{30}$ Michael R. Ward, "Okot p'Bitek and the Rise of East African Writing," in A Celebration of Black and African Writing, eds. B. King and K. Ogunbesan (Zaria: Oxford University Press, 1975), p. 224. 
after the fashion of Song of Lawino, as is illustrated by the following passage which laments the influence of money: 'Metals, metals, metals. These metals are killing us. These ones they call money are driving us mad.' The novel ends on a note of appeal when Rosa, the prostitute, pleads for her death not to be noticed. Oculi also uses the kind of appeal phrases that are typical of okot p'Bitek's writing as in chapter six which begins with the phrase: 'Bisi! Bisi! My man Bisi. . .' Prostitute attempts to combine the lament tradition in poetry with the form of modern novel. 31

The most important contributions of okot p'Bitek to style of East Africa are his independence of Western forms, his success in experimentation with oral literature, and, in general, his creative imagination. He has originated a style in which he uses proverbs, images and symbols taken from East African oral literature, especially symbols from Acoli oral literature. Okot's use of African images helps to retain the meaning of African ideas. For example, one significant proverb central to the whole poem, Song of Lawino, is addressed by Lawino to her husband, warning him not to destroy Acoli customs and ways of life unnecessarily:

Listen, my husband, You are the son of the chief. The pumpkin in the old homestead Must not be uprooted! 32

Pumpkins either grow wildly around the house or they are

${ }^{31}$ Ibid., p. 225

${ }^{32}$ p'Bitek, Song of Lawino and Song of Ocol, p. 48. 
cultivated in African communities. The leaves of pumpkins are eaten as green vegetables. The fruit from the pumpkin is also cooked and eaten. Being luxury food, the pumpkins are eaten only once in a while. However, when the owner of the homestead is migrating or moving to another home, he does not "uproot the pumpkin in the homestead." similarly, Okot says the Africans who receive Western education should not destroy and abandon their customs. Okot here makes an appropriate comparison between Ocol's rejection of his African values and the fact that the "pumpkin in the old homestead should not be uprooted." This kind of metaphor is rarely obscure or unclear to African readers, but the nonAfrican readers, in general, may not feel the dramatic and thematic implication of the proverb. The African readers are able to get the message very clearly without distortion. Consequently, the advantages of using such forms of oral literary heritage are many. The analyses of these ideas and Okot's techniques for their expression in his poetry are the subject of our study.

\section{Outline of Issues and Scope \\ for This Study}

Chapter two will discuss the basic themes of okot p'Bitek's first long poems in English, song of Lawino and 
Song of Ocol. These two works are related. Both concern the conflict of traditional ideas, values and practices with those introduced by Western influences. Both employ the same two main characters, a husband and wife in a troubled marriage. Lawino, the wife, defends the arts, crafts, religion and education of traditional life. In answer, her Westernized husband, Ocol, argues that East African cultures are "primitive" and must yield to Western progress. The discussion will demonstrate how okot plants in Ocol's words thoughts which lead the readers to condemn or reject both Ocol's thoughts and his personality.

Chapter three will discuss the major issues of Song of A Prisoner and Song of Malaya, two less related works which, nevertheless, have in common that they address the problems of African life after political independence. Song of A Prisoner is devoted to political issues: tribalism, economic deprivation, and other inequities. Song of Malaya addresses more private, moral concerns, specifically promiscuity and prostitution. In this case okot emphasizes the irrationality and hypocrisy of those who wish to impose a Christian morality upon their society.

The fourth chapter will discuss the literary techniques which okot uses in the four Songs. I will show that 
he establishes a dramatic base for a thematic structure. This arrangement allows him to discuss a variety of themes associated with a particular topic without sacrificing the poetic intensity of real people speaking in earnest sincerity. I will discuss the dramatic elements such as characterization and plot structure, and then such features as humor and satire, imagery and rhetorical features, in order to demonstrate how the entire composition is designed to support Okot's didactic intent.

Chapter five will contain a summary and conclusions of the study. 
CHAPTER II

THEMES IN "SONG OF LAWINO" AND

"SONG OF OCOL"

The central objective of this thesis is to clarify

Okot's message in the poetry under discussion. Many people have misunderstood and misinterpreted okot's intention in his poetry. As one critic, David Rubadiri says:

Some readers have suggested that (Okot's message) is the negative rejection by okot of a world heritage, a negative cry of: "Back to savage nature:'; that one shouldn't read books; that what okot is saying is that one shouldn't go to university; one shouldn't wear shoes; one shouldn't use forks, and so on. But when you get the full impact of it you find that this is just a surface interpretation of the thing and $I$ reject this view myself. It is a narrow and subjective reaction to what the poet is actually trying to say. To me it is still the same continuous argument of the theme of a search for an identity that is meaningful and the meaningful must surely be that which first understands itself, before it enriches itself with another. 1

Another East African writer, Okello Oculi, is also aware that

${ }^{1}$ David Rubadiri, "The Development of Writing in East Africa," in Perspectives on African Literature, ed. Christopher Heywood (Ibadan: University of Ife Press, 1974, p. 154 . 
many readers have misunderstood okot's message.

Okot was accused of crying for the simple, routine, boring, unsophisticated, primitive, savage culture of yesterday--if not yesterday, of the village, the life of the people. And okot was depicted as somebody completely ungrateful to all the civilizing energies-the missionary, the gold mining prospector, the copper mining prospector, the businessman and so on and so forth. 2

Okot is definitely not "crying" for the "primitive, savage culture" of yesterday. In his poetry, Okot is concerned with portraying the positive values of African traditional society. He is also concerned with some common changes that took place as a result of Western colonization of Africa. Some changes are good and approvable, as one of the critics, Maina Gathungu, observes in answering over-simplified interpretations :

Who surely does not want to read? Who does not like his wife the more when she 'lightly' applies some sweet smelling powder? If one goes to work (I notice that Lawino does not raise objections to this), isn't a watch inevitable? Can this factor be entirely discarded in this age? ${ }^{3}$

Some readers further misunderstand the meaning of okot's

2 Okello Oculi, Interview in African Writers on African Writing, ed. G. D. Killam (London: Heinemann Educational Books Press, 1973), p. 129.

${ }^{3}$ Maina Gathungu, "Okot p'Bitek: Writer, Singer or Culturizer," in Standpoints on African Literature, ed. Chris Wanjala (Nairobi: East African Literature Bureau, 1973), p. 58 . 
poetry when, for example, they interpret Song of Lawino without considering its deeper meaning. Such readers view Song of Lawino as a simple personal story.

Ngugi wa Thiong'o observes that:

- . such people thus turn the fundamental opposition between two value systems into a mere personal quarrel between Lawino and her husband. 4

Nonetheless, there are some critics who have succeeded in grasping the meaning articulated in the poetry of Okot p'Bitek. These include Ali Mazrui, Michael R. Ward, Donald E. Herdeck, Ngugi wa Thiong'o and others. However, critics do offer contrasting interpretation of okot p'Bitek's poetry. For example, in their discussion of Song of A

Prisoner, Margaret Marshment and Edward Blishen offer contrasting views. As Margaret Marshment asserts:

In his introduction to the American edition of Song of A Prisoner, Edward Blishen says:

The Prisoner cannot be read as a single character. At times he is Patrice Lumumba, being beaten to the point of death; a betrayed hero of Uhuru. At other times he seems to be any political detainee, imprisoned for his opinions or his political actions. Again he is an assassin, who has rid his country of a tyrant, who pretends wildly not to understand why his captors do not form a guard of honour for him.

${ }^{4}$ Ngugi wa Thiong' 0 , Homecoming (New York: Laurence Hill Company Press, 1972), p. 75 . 
This is wrong. The prisoner is a single character. 5 In contradiction to Edward Blishen's view, Margaret Marshment says :

Song of A Prisoner is a poem about African society after independence, and as such naturally gives rise (or should do) to questions about the artist's vision of and responsibilities to that society. 6

Given such differences among serious critics, there is value in reexamining the themes and the techniques by which the themes are conveyed. The preceding discussions center upon the four long poems which are the subject of this paper. They are:

Song of Lowino (1966)

Song of Ocol (1967)

Song of Malaya (1971)

Song of A Prisoner (1971)

These poetical works are the ones which most critics agree represent the author, Okot p'Bitek, at the height of his talent.

The basic concern of the present chapter is the conflict between traditional values and Western values as

${ }^{5}$ Margaret Marshment, "Okot p'Bitek and Two Songs: A Discussion," in Standpoints on African Literature, ed. Chris Wanjala (Hairobi: East African Literature Bureau, 1973), p. 128.

$$
{ }^{6} \text { Ibid., p. } 125 \text {. }
$$


articulated in Song of Lawino and Song of Ocol.

In the first part I will consider the contrast of Western values with traditional values as discussed in song of Lawino. Here Okot's views of inherent strength and structure in traditional society will be discussed as well as his views of the falsity of Western society's claims to superiority, especially the claims of Christianity. Then I will discuss the harmful effects of Western values on African peoples, as they are conveyed first in Song of Lawino and secondly in song of Ocol. The central harmful effect in song of Ocol is self-hatred. After discussing the ill effects of Western education with its self-hatred and other consequences outlined in Song of Ocol. I will discuss the more serious political criticism that okot voices in Song of Ocol. The issues include dictatorship, capitalism, and the absence of equality in past independent African governments .

Song of Lawino, published in 1966, ranks as a major pioneering achievement in East African writing for a variety of reasons. According to the critic, Michael R. Ward, "Its reference to traditional forms "7 contributes to its

${ }^{7}$ Michael R. Ward, "Okot p'Bitek and the Rise of East African Writing," in A Celebration of the Black and African 
significance. Ali Mazrui views it to be important because "it is a passionate soliloguy, an utterance of cultural nationalism." 8 Okello Oculi says "There's really no other work that has succeeded in touching the African nerve as Song of Lawino." 9 Ngugi wa Thiong'o agrees with other critics on the importance of Song of Lawino in East African writing.

Song of Lawino is the one poem that has mapped out new areas and new directions in East African poetry. It belongs to the soil. It is authentically East African in its tone and in its appeal. This can be seen in its reception. It is read everywhere, arousing heated debates. Some critics have even attempted a psychoanalysis of the creator of Lawino. It is the first time that a book of modern poetry has received such popular widespread acclaim. The effect on the young poet has been no less stunning. Many want to write like Okot p'Bitek.10

Song of Lawino is a "long narrative poem."11 some

Writing, eds. B. King and K. Ogunbesan (Zaria: Oxford University Press, 1975), p. 224.

$8_{\text {Ali Mazrui, "Song of Selfhood," in African Writers }}$ On African Writing, ed. G. D. Killam (London: Heinemann Educational Books Press, 1973), p. 85.

9 okello Oculi, Interview in African Writers on African Writing, p. 129.

${ }^{10}$ Ngugi, Homecoming, p. 75 .

${ }^{11}$ Donald E. Herdeck, et al., eds.. African Authors: A Companion to Black African Writing, 1300-1973 (Washington, D. C.: Black Orpheus Press, 1973), p. 339. 
people call it a "poetic novel,"12 or a "lament,"13 or a "long dramatic poem." 14 Each of these terms is partially correct. Okot wrote it originally in Luo, his mother tongue, as Wer $\mathrm{Pa}$ Lawino, which in 1966, the author translated into English, as Song of Lawino. The poem is a study of the effects of colonization and westernization on African ways of life. It is a study of the opposing approaches to cultural life taken by the African elite and the ordinary folk.

To present his case, Okot uses as his mouthpiece, Lawino, a female protagonist; a rural, unwesternized, traditional woman married to Ocol, an African who has received Western education. Influenced by his Western education, ocol abandons his rural wife, Lawino. Consequently, Lawino addresses her husband in an attempt to reason with him. Ocol's central reason for abandoning Lawino is that she has not received western education. According to ocol, she is primitive, and her behavior is primitive and backwards. In the course of reasoning with Ocol, Lawino unfolds many things about their past and present relationships. Consequently,

$$
{ }^{12} \text { Ibid. } \quad{ }^{13} \text { Ibid. }
$$

140. R. Dathorne, The Black Mind: A History of African Literature (Minneapolis: University of Minnesota Press, 1974), p. 300 . 
the readers find out that ocol is in love with a mistress, clementine, who is of the "new world." She behaves in Western ways. She uses lipstick on her mouth. She puts powder on her face. She bleaches her skin, she pads her breasts, and she behaves in other Western ways which Ocol considers ideally beautiful. As Lawino says:

Ocol rejects the old type.

He is in love with a modern woman,

He is in love with a beautiful girl

who speaks English.

Ocol is no longer in love with the old type

He is in love with a modern girl The name of the beautiful one is Clementine. 15

Consequently, Lawino "laments" her husband's abandoning her simply because she does not imitate Western values. As Lawino's account unfolds, we learn how traditional ways of life are valid and positive. She also demonstrates how African ways of life not only contribute to the inherent strength and structure of African society, but how these ways enhance the Africans' capacity to express themselves fully and freely. To portray this, Lawino comments on many aspects

${ }^{15}$ Okot p'Bitek, Song of Lawino and Song of Ocol, A Combined School Edition (Nairobi: East African Publishing House, 1972), p. 41 .

All subsequent references to the poem will be cited in the text by page number from this edition. 
of life in East Africa, such as the aesthetics (in dances, human beauty, the practical crafts and food), religion, politics and education. We discover that ocol thinks that in all the above mentioned matters, the African values are primitive and must be destroyed and replaced with Western values. Lawino thinks otherwise. In fact, Lawino demonstrates how the so-called superior Christian religion is hypocritical and how western ways in general can be dirty, stupid and inappropriate to African people. As Ngugi wa Thiong'o puts it:

Lawino is not rejecting the validity of western culture, to her every culture is valid to the community and the condition that created it. What gnaws at her is that self hatred that makes the Ocols totally reject and even consciously repudiate their roots in the African Peasant World: they even go further and uncritically accept the half digested mannerisms of European bourgeois. 16

Song of Lawino is based on a real social problem, experienced in many rural places in East Africa. Initially, in East Africa, men received education up to higher levels than women. Some even went abroad for further studies, leaving their wives in rural villages. The result was that there was often trouble when a husband with all his Western ideals returned to live with his wife who remained entrenched

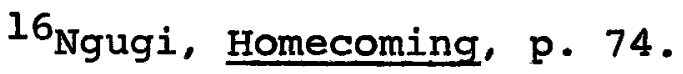


in her African values. Such marriages sometimes dissolved, especially if the husband behaved like 0 col and had contempt for all the African ways of life held by his wife and family. Okot utilizes the dramatic impact of such a common domestic problem to express his points about the future of Africa.

In Song of Ocol, first published in 1967, the husband presents his side of the argument. Some critics call song of Ocol, a "prose poem."17 It is much shorter than song of Lawino and divided into nine chapters, unlike song of Lawino. which is divided into thirteen. When compared with song of Lawino, most readers find Song of Ocol less dramatic, but easier to read aloud. In Song of Ocol, the lines and chapters are much shorter than those of Song of Lawino. Song of Ocol is more easily read by any English speaking people, regardless of their origin, because it lacks heavy reliance on oral literature. This reduces its richness in imagery and language. However it remains rich in all forms of imagery: similes, personification, metaphors, and others.

Song of Ocol begins with their divorce. Ocol confirms the assertions made by Lawino in the earlier work. He is abusive, arrogant and rude. He is very bitter and unreasonably critical in his speech. The author makes ocol

${ }^{17}$ Herdeck, et al., African Authors, p. 340. 
condemn himself, without in fact realizing that he is condemning himself. Although educated in Western ways, Ocol is unreasonable. When Lawino sincerely asks him questions, Ocol is unwilling to reason with her. Instead, he chases her from his house:

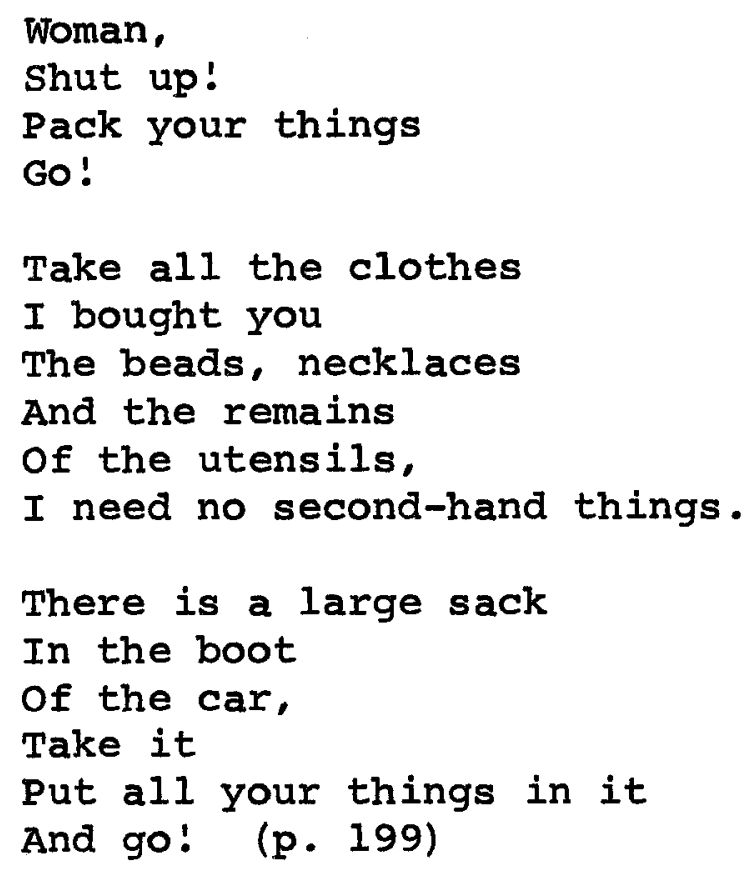

Okot plants in Ocol's words sentiments which show that Ocol is not just condemning his continent, community and family as primitive, but also unconsciously condemning himself as evil and foolish.

Thus we have two monologues, one in answer to the other. But both are designed to demonstrate Okot's views, one directly, the other indirectly. Ironically, in order to assess the total thrust of the argument, we must first analyze the themes in Song of Lawino, and then see how they 
are reaffirmed and expanded in song of Ocol.

As we have said, in portraying the inherent strength and structure of African society, Okot begins Lawino by addressing simple issues of aesthetics. However, he weaves into the descriptions an explanation of the cultural significance of African (Acoli) concepts of beauty. Meanwhile, he also shows how inappropriate Western concepts of beauty are in Uganda.

Acoli aesthetics is one of the aspects of the culture that Okot vividly portrays throughout Lawino. Acoli expressed themselves artistically through the dance and music (particularly singing and playing on the harp). Lawino does not know how to dance "the dances of white people" (p. 49), but she knows and can dance the Acoli dances.

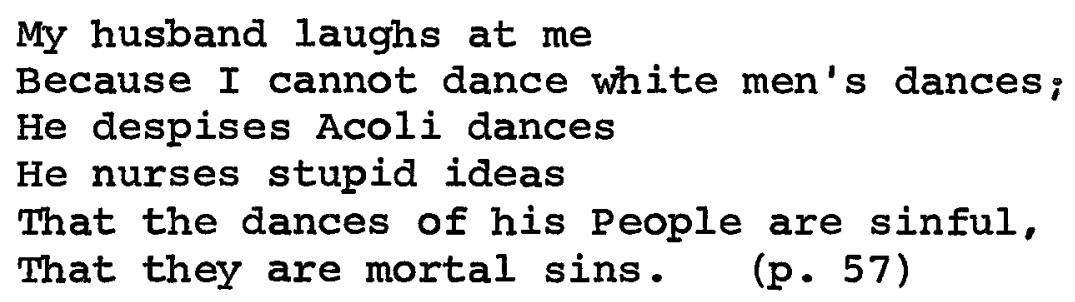

In attacking this negative attitude about his people's dances which Ocol has acquired from Westerners, the author portrays the significance and importance of dance in Africa. Okot attempts to inform Ocol and his elite counterparts of the positive value of dance in Africa. Therefore Okot portrays 
the openness, beauty, liveliness and healthiness of Acoli dance.

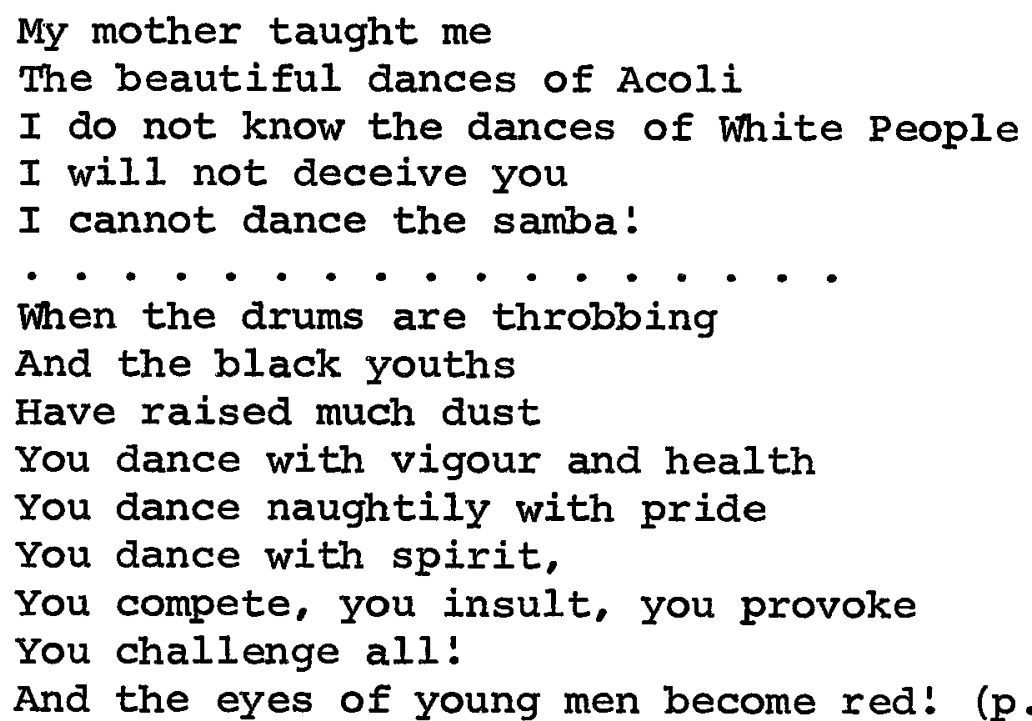

Acoli dances are of course accompanied with music. The Acoli dancers sing and dance simultaneously, unlike the "whites, who do not sing as they dance. They dance silently like wizards." (p. 52) The importance of both music and dance here is that not only are they healthy and enjoyable, but they are valued as a form of expression for:

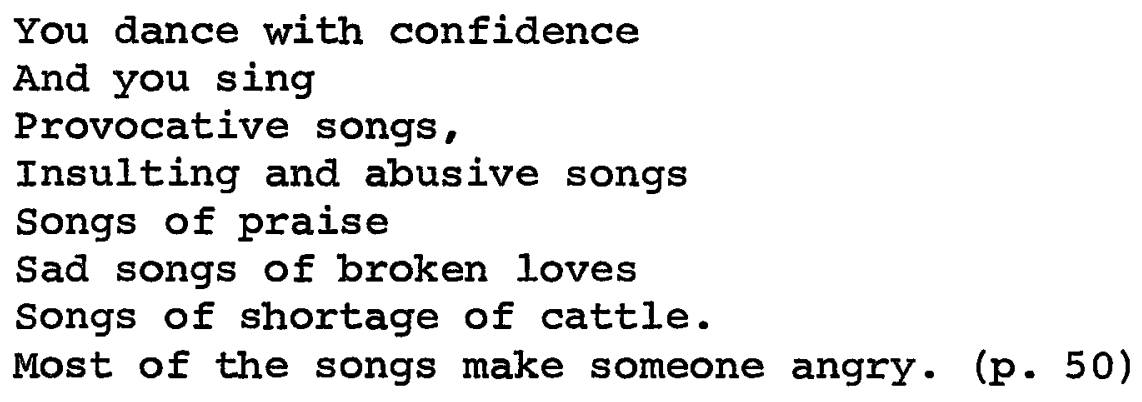

It is at the dances that people can perceive what type of 
person one is. "A man's manliness is seen in the arena."

Lawino also praises and appreciates Acoli dance because:

It is danced in broad daylight

In the open

You cannot hide anything,

Bad stomachs that have swollen up.

Skin diseases on the buttocks

Small breasts that have just emerged

And large ones full of boiling milk,

Are clearly seen in the arena

Breasts that are tired

And are about to fall,... (p. 50)

Lawino further comments on the significance and importance of dance owing to its openness and liveliness. The participants are active and not dull.
All parts of the body
Are shown in the arena!
Health and liveliness
Are shown in the arena!
When the daughter of the Bull
Enters the arena
She does not stand there
Like stale beer that does not sell,
She jumps here
She jumps there.
When you touch her
She says 'Don't touch me:' (pp. 51-52)

To use the East African critic, David Rubadiri's words:

The point being made here is that the dance is an expression of an individual as well as a communal meaning of life within the African community, an identification of life as opposed to being merely the type.18

Lawino gives a detailed description of the significance of

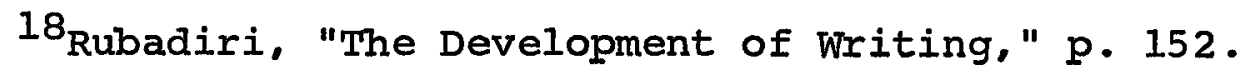


dance in Africa to answer the charge made by Westerners that Africans dance naked. Lawino answers by an attack. She argues that Western dances are immoral, irrespective of Western society's claim to be finer or more moral than African society.

Western dances are immoral because people embrace in public and with anyone even close relatives.19

Among African norms, there should be distance between relatives. But Lawino gets a shock when the white people dance in darkness, holding each other. This is a sign of shame to her.

Each man has a woman

Although she is not his wife, They dance inside a house

And there is no light. Shamelessly, they hold each other Tightly, tightly They cannot breathe:

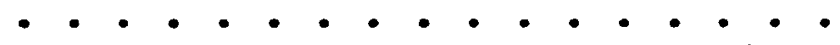

There is no respect for relatives: Girls hold their fathers, Boys hold their sisters close, They dance even with their mothers. Modern girls are fierce.

They coil around their nephews And lie on the chests of their uncles And prick the chests of their brothers With their breasts. (pp. 53-54)

In short Lawino argues that the conventions of Western dance are rife with immoral implications.

${ }^{19}$ Heron, Introduction in Song of Lawino and Ocol, p. 20. 
To elaborate on Acoli aesthetics, Lawino also discusses Acoli adornments, decorations, and hair styles, and emphasizes that they are beautiful. She establishes this in order to defend herself against Ocol's complaint that she does not know "modern beauty."

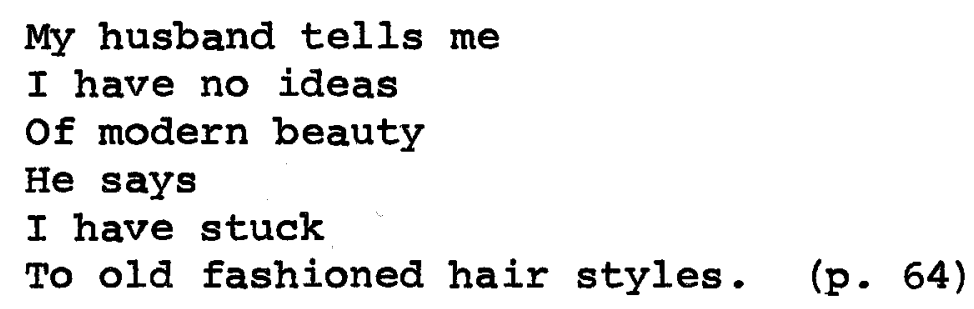

Answering Ocol, Lawino comments that Acoli hair styles are appropriate and beautiful so long as they are done on Acoli hair.

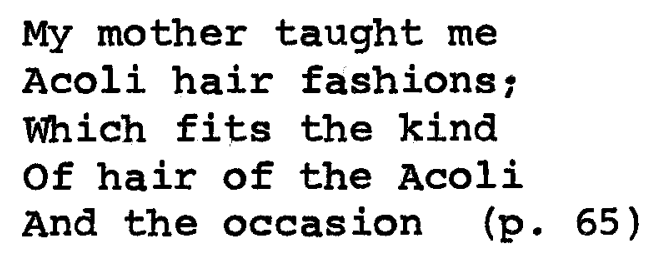

Owing to its structure, Acoli hair, like most African hair, is different from other kinds of hair, such as European hair or Asian hair. As a result of this difference, the western hair styles are neither appropriate to African hair in general nor Acoli hair specifically.

The hair of the Acoli

Is different from that of the Arabs; The Indians' hair Resembles the tail of the horse; It is like sisal strings And needs to be cut With scissors. 
It is black,

And is different from that of white women.

(p. 65)

Acoli hair is styled beautifully, but differently, depending on the situation, that is, depending on the kind of occasion and the type of dress.

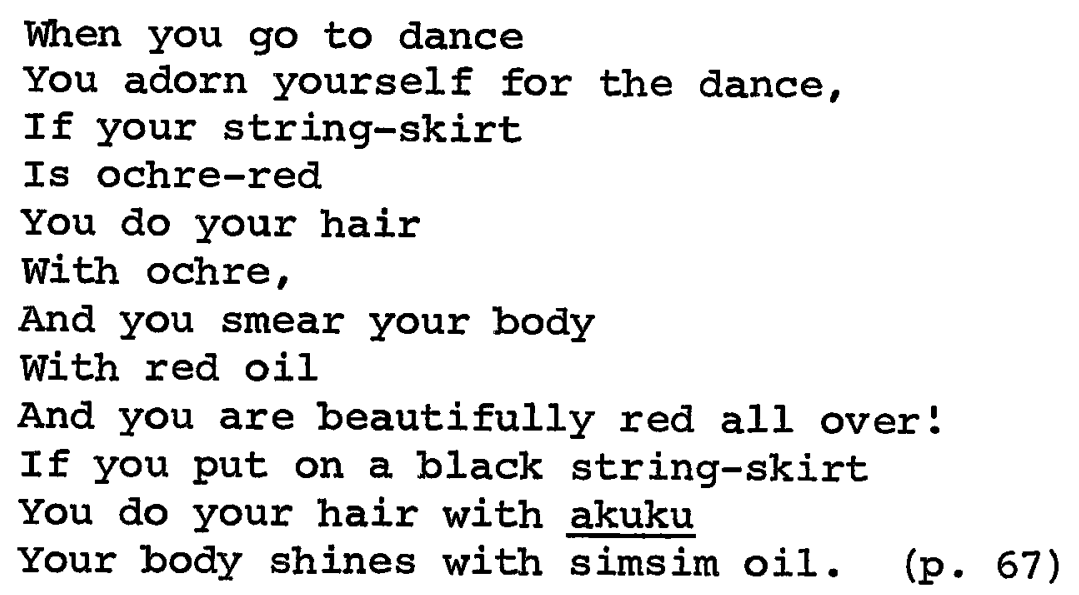

Lawino, while showing how Acoli adornments are beautiful and appropriate to the Acoli people nevertheless acknowledges that her husband Ocol does not appreciate the Acoli ways of adornment.

He says, Acoli adornments

Are old fashioned and unhealthy.

He says I soil his white shirt

If I touch him.

My husband treats me

As if $I$ am suffering from

The 'Don't touch me' disease:

Ocol says

I look extremely ugly

When I am fully adorned

for the dance! (p. 70)

Lawino does not see anything wrong with Acoli adornments, 
and hence she lashes back at Ocol:

Like beggars

You take up white men's adornments,

Like slaves or war captives

You take up white men's ways.

Didn't the Acoli have adornments?

Didn't Black people have their ways? (p. 62)

On the contrary, Lawino finds that Western hair styles are not appropriate to Acoli hair. They seem unreal and absurd:

They cook their hair

With hot iron

And pull it hard

So that it may grow long.

Then they rope the hair

On wooden pens

Like a billy goat

Brought for the sacrifice

struggling to free itself. (p. 71)

Lawino does not admire women like clementine "who cooks her hair" because when

She returns from cooking her hair

She resembles

A chicken

That has fallen into a pond;

Her hair looks

Like the python's discarded skin. (p. 70)

Sometimes they "even smear black polish" (p. 71) or they wear wigs

Sometimes she wears

The hair of some dead woman

of some white woman

Who died long ago

And she goes with it

To the dance:

What witchcraft! (p. 73) 
One day the false hair was taken off by some mysterious power:

One night

The ghost of the dead woman

pulled away her hair

From the head of the wizard

And the beautiful one

Fell down

And shook with shame

She shook

As if the angry ghost

of the white woman

Had entered her head. (pp. 73-74)

Lawino does not admire such artificial beauty, although ocol

does. Instead she asserts:

I am proud of the hair

With which I was born

And as no white woman

Wishes to do her hair

Like mine,

Because she is proud

of the hair with which she was born,

I have no wish

To look like a white woman. (p. 74)

"Be content with what you are" is her wish because

No leopard

Would change into a hyena,

And the crested crane

Would hate to be changed

Into the bold-headed,

Dung-eating vulture,

The long-necked and graceful giraffe

Cannot become a monkey. (p. 74)

Thus, in conclusion, we find that okot's treatment

leads to more than just a defense of Acoli adornments. Instead, he proves that behind this superficial issue there 
lies the greater issue of self-acceptance and self-pride. The practical crafts of the Acoli are portrayed and compared to those of Westerners. Okot, through Lawino, paints a detailed picture of a typical Acoli house, what it looks like, what it contains and its significance. And with this picture, okot discusses the solid structure of Acoli (African) and all culture. "At the foot of the pole is my father's revered stool," says Lawino. As the head of the household, a father has some special possessions. One of these is the stool. What Lawino is saying is that tools and utensils in Acoli houses may be referred to as "primitive" by those who are strange to Acoli's way of life. Nevertheless, all the tools available in an Acoli household were skillfully moulded to serve various appropriate functions in the Acoli life. For example, the Acoli were clever enough to mould pots which serve the purpose of "cupboards" and "stores" in the Western sense of the terms. As Lawino observes:

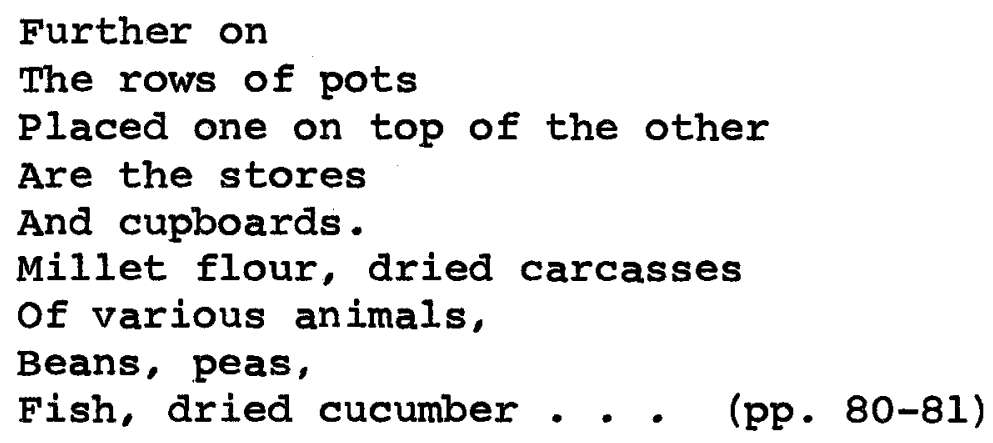

For the Acoli to appropriately preserve their various 
foodstuffs they cleverly make a variety of pots and baskets to suit storing specific kinds of food. For example,

The beautiful long-necked jar

On your left

Is full of honey

That earthen dish

Contains simsim paste;

And that grass pocket

Just above the fireplace

contains dried white ants. (p. 81)

Owing to the fact that dried white ants had to be kept ary, the best storage container is a "grass pocket" placed directly above the fire, so that the heat from the fire would continuously keep it always warm and dried. similarly, the Acoli household has no Western plates because, for example, the half-gourd is ideal for storage of millet bread which grows cold and wet on such plates. By such examples, Okot demonstrates the ingenuity by which the crafts are adapted to the culture and physical environment, and Western artifacts often are not.

Just as she did with crafts, Lawino gives a minute description and spirited defense of traditional Acoli food such as millet, flour, beans, peas, fish and dried cucumber. She asserts their nutritional value as well as their good taste. She finds "whitemen's food" disgusting. Ocol, of course, is fond of Western dishes, and tries to introduce Lawino to "raw eggs," "chicken," "lobster," "frog shells," 
"tortoise," "snakes" and so forth. What bothers Lawino is that Ocol

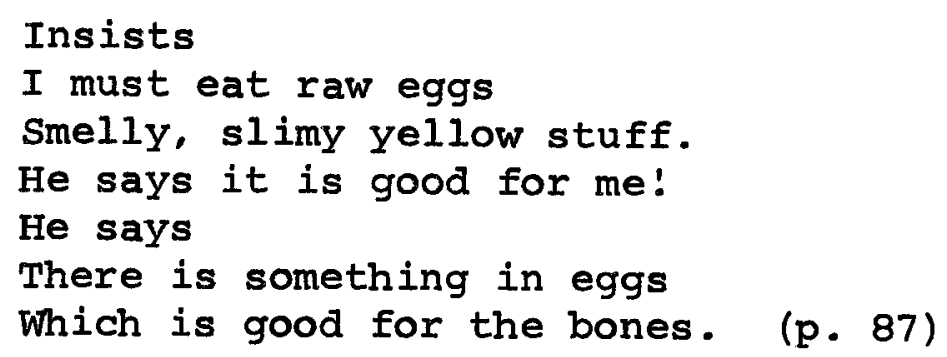

But Lawino is confident that the Acoli diet has given her strong bones and general health. As she had said in talking of aesthetics:

But my bones are strong,

I can dance all night long

Listen to the song

They sang about me:

The beautiful one

Dances all night long...(p. 87)

As she puts it here:

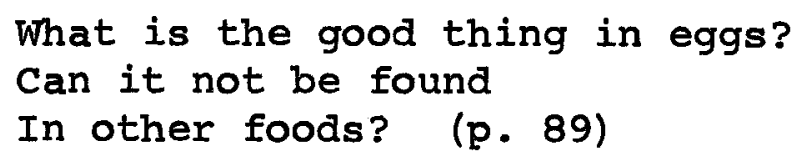

In summary, to Ocol's claim that "Black people's foods are primitive" (p. 87) Lawino asks, "But what is backward about them?" (p. 87) and finding no credible answer, her conclusion is that each should enjoy his own preference.

My husband

I do not complain

That you eat

White men's food

If you enjoy them

Go ahead! 
Shall we just agree

To have freedom

To eat what one likes? (p. 89)

Again, Lawino vividly describes the cooking equipments used by Acoli:

On the far right

Is the cooking place.

The fireplace in my mother's house

Is dug into the earth.

The wife of my mother's brother

Has the Lango type,

Three mounds of clay

Shaped like youthful breasts full of milk

stand together like

Three loving sisters.

I do not know

How to use foreign stoves,

My mother taught me

Cooking on the Acoli stove

And when I visited

My mother's brother

I cooked meals

On the Lango stove. (p. 84)

Lawino finds it more comfortable to cook on Acoli cooking equipment, and she strongly feels that:

Whitemen's stoves

Are for cooking

Whitemen's foods

They are not suitable

For cooking

Acoli foods

And I am afraid of them. (p. 87)

Besides their inappropriateness for Acoli food, whitemen's cooking machines such as the Primus, charcoal and electric stoves have other disadvantages. For instance, Lawino says 
about the Primus stove:

They say

It once burst

And the flame burnt

A goat to death! (p. 76)

Lawino is also aware that "The electric fire kills people." (p. 77) In the end of this section, Lawino concludes that she does not know, and she does not like to use, white people's utensils and cooking machines. Therefore, she rejects Ocol's demand that she use them.

With regard to cooking and food, Lawino's position, therefore, is similar to her position regarding clothing and dance: Acoli practice has its merits; Western practice has its faults, especially for Africans. The Western customs are not absolutely condemned, but they are scorned, and any claim of their superiority is disapproved.

In all the above discussion, one finds that okot's message was illustrated by concrete things, the aesthetics by such things as arts, dance, and music; human beauty by physical health, decoration (ornaments), hair styles; and finally the practical crafts by such examples as cooking equipments, and various foodstuffs of the Acoli (African) traditional community, in comparison with those of the Western world. Okot's later messages to be discussed in this paper are portrayed through more abstract subjects, such as 
time, Missionary education, Christian myths, medicine and politics. All these abstract subjects fall under either the traditional education and its values, or the ill effects of Western education on African family. The falsity of Western society's claim to be more genuine than the Africans, especially the claims of Christianity, are exposed, and the positive values of traditional Acoli religion are portrayed. African traditional education is conveyed directly in song of Lawino. It is shown to be valid and suitable to the African communities. It does not require one to learn alphabets, or to attend formal classes for a certain period and then to graduate. Rather, it is a holistic type of education, in which one is brought up from infancy to acquire certain skills and experiences throughout a life time. Lawino realizes that Westerners are negative about such an education. This is evident in Ocol's inappreciation of Lawino:

You say I do not know the letter A Because I have not been to school. (p. 36)

However, through her description, one finds that Lawino knows everything that she requires to live a life in an Acoli community. And as to how she acquired whatever she knows, she is clear:

My mother showed me many medicines. (p. 153) 
My mother taught me

cooking on the Acoli stove. (p. 84)

My mother taught me

Acoli hair fashions. (p. 65)

And finally she says:

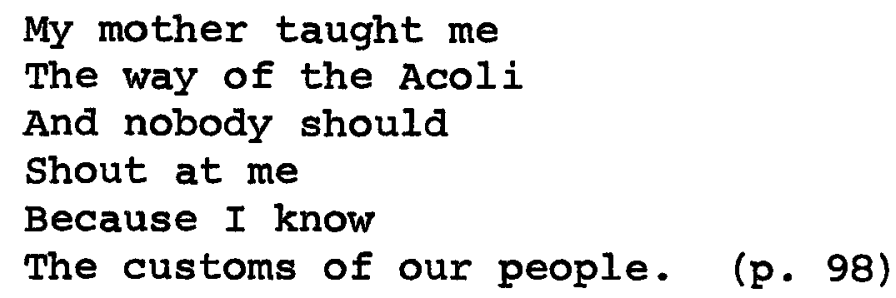

Not only does she acquire education from her mother but also from the whole society. In many African communities, traditional education involves various roles. For example, a young girl is from the beginning trained in her future responsibilities of being a wife and eventually a mother. Consequently, she is trained by her female relatives including her mother and her grandmother to know how to keep a house, how to cook for her husband, how to bring up and rear children, practical crafts, human beauty and all other things essential to her lifestyle in that community. This is demonstrated by Lawino. Through her description of various East African aspects of life, one can deduce that she has received good education for the lifestyle of her community. She understands traditional aesthetics and a wide range of the practical crafts. She knows all kinds of food essential for a balanced diet. She can cook. 
Lawino knows all types of traditional Acoli medicine and their usage. She tells Ocol how traditional medicine is very powerful and effective. In defense of Ocol's condemnation of all traditional medicines as ineffective, Lawino gives a detailed account of the Acoli way of dealing with disease and misfortunes. She admits that she does not know "the whiteman's names of diseases" (p. 151) and she does not know"the names of their medicines" (p. 151), but she knows Acoli diseases and various Acoli medicines that she uses to cure them. In a detailed description (pp. 153-154), she shows that before the influence of Europeans on East Africa, the East Africans were versed in a wide variety of herbs, which they effectively used to treat different kinds of diseases. She is of course correct. Even after European introduction of hospitals, one finds that some people in East Africa still depend on certain kinds of traditional herbs to treat certain diseases more effectively than hospital medicine often can. Lawino describes how parents, relatives, and the community at large normally introduce the young generation to various herbs and explain which diseases they treat. This process continues from generation to generation. However, whoever is responsible for introducing the youngsters to lay remedies also advises them to try the 
professional medical man or woman in case the home remedy has inadequate effect. As Lawino says:

I try the various medicines That my mother showed me, If all these fail

I go to the medicine woman. And when the child has improved

I take a chicken to the herbalist, Or a goat or a ram. (p. 154)

Similarly, Lawino learns from her society that, if a person (child) dies, then she should consult a diviner priest to learn the killer's identity.

A diviner--priest must be called. He will divine And tell the killer, The jealous one will be found out! (p. 155)

Sharing Okot's view in Religion of the Central Luo, Lawino in her detailed account treats ritual activities as an extension of medicine. Okot had said:

The beliefs and practices I have described and certain knowledge of medicines were used to diagnose, explain, interpret the individual cause of misfortune and illhealth, and they also provided means and ways of coping with individual situations of anxiety and stress.20

The traditional medicines are so powerful that not only do they cure physical diseases but also psychological diseases. For instance, Lawino tells us that the medicine could even

200kot p'Bitek, Religion of the Central Luo (Nairobi: East African Literature Bureau, 1971), p. 160 . 
cure Ocol's disease of being a "walking corpse" (p. 187) as a result of reading too many books. The diviner would cure his failing eyesight, for example. (p. 194) Lawino does not see the reason why she should abandon or despise them. She points out that white men's medicines also have their strengths and weaknesses, since

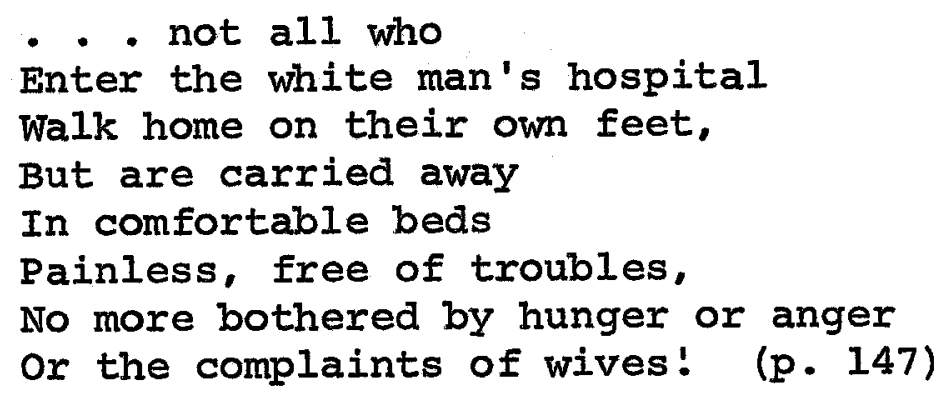

Lawino takes time to describe the validity as well

as weaknesses of traditional medicine because the Western point of view as stated by Ocol is negative about them. Ocol condemns all traditional medicines. But Lawino insists that both the Acoli and Western medicines cannot defeat the most serious calamities such as death

White diviner priests, Acoli herbalists,

All medicine men and medicine women

Are good, are brilliant

When the day has not yet dawned

For the great journey

The last safari

To Pagak. (pp. 165-167)

We can see the necessity for such an elaborate defense of African medicine when we contrast Ocol's blanket condemnation. 
Ocol agrees only "That sometimes by accident/some of the herbs are effective." (p. 147) He propagates the myth that all African medicine and rituals are worthless as a way of dealing with medical problems in the community, and that European medicine should replace them completely.

Ocol condemns diviner-priests

And Acoli herbalists.

He says

They are all liars

Who deceive fools,

And robs people's chickens,

Goats, sheep, cattle and money.

Their so-called medicines

Are dirty mixtures

of all sorts of things

Collected from the bush

And mixed in beer. (p. 147)

Through Lawino, Okot attempts to disprove this commonly held misconception.

Traditional perception of time, also learned through holistic education, is another topic in Song of Lawino. Lawino is not aware of seconds, minutes, and months of the year because they do not exist in Acoli thought.

I do not know The names of the moons Because the Acoli

Do not name their moons. (p. 103)

But she knows seasons of the year, and the particular events or duties associated with each. In her African sense, seasons of the year are analogous to Western time; before 
Western colonization, members of her society did everything according to seasons but not according to clocks and calendars.

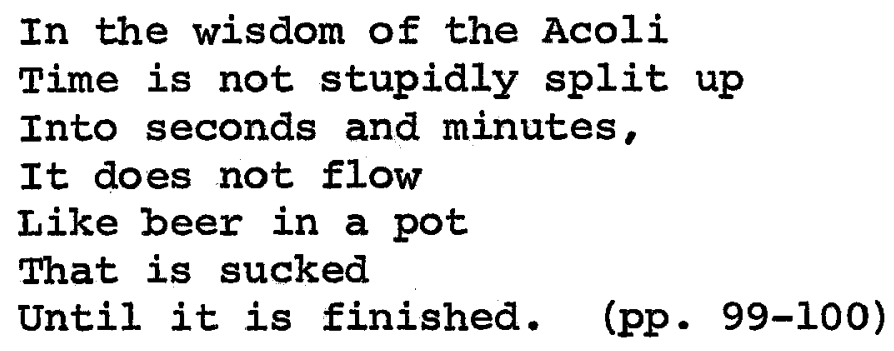

Therefore Lawino catalogues the rhythms of the seasons. Just before the rainy season, for example, the millet is sown. In the rainy season, the millet grows to a point of harvest. It is during the harvest season that people have the hardest regimen of work. On the other hand, the dry season offers more time for relaxation, music and dance. It is also the season for hunting. Ocol, of course, does not appreciate the perspective that governs Lawino's perception of time. After expounding the Acoli experience of time, Lawino attacks Ocol's obedience to the clock which she cannot read.

If my husband insists What exact time He should have morning tea And breakfast, When exactly to have coffee And the exact time For taking the family photograph-Lunch-time, tea time, And supper time-- 
I must first look at the sun, The cock must crow

To remind me. (pp. 91-92)

Lawino finds it strange to have to do everything by the clock. Ocol insists that Lawino should breastfeed at fixed times, but in the Acoli community,

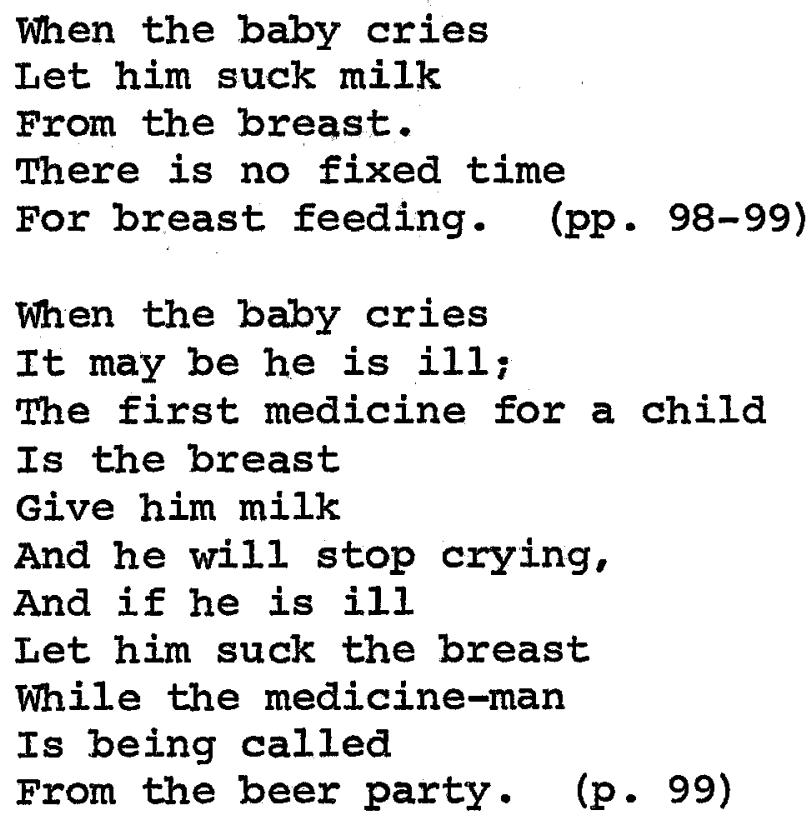

Similarly, children go to bed "when sleep comes/Into their head" (p. 99) and get washed when dirty. "You do not first look at the sun!" (p. 99) Ocol's own fear of wasting time puts a further strain on their marriage.

Ocol does not chat

With me,

He never jokes

With anybody,

He says

He has no time

To sit around the evening fire. (pp. 95-96)

Furthermore, 


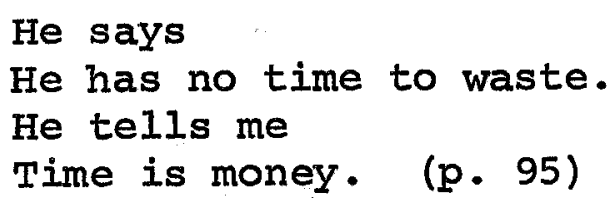

Time has alienated ocol from his family and other visitors. For time, he sacrifices dignity and etiquette:

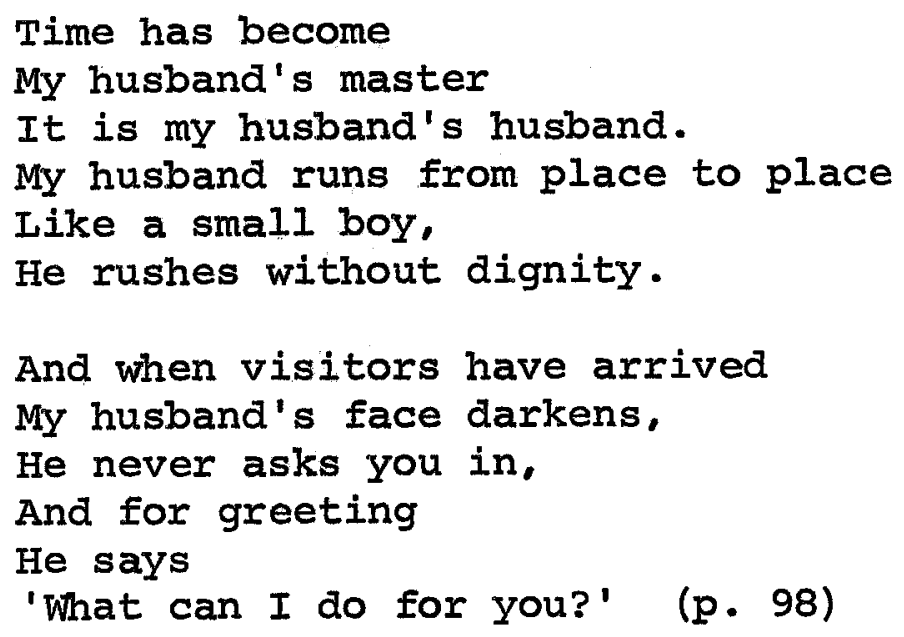

In order to understand the breach of etiquette here, it is necessary to understand the African's (or at least Acoli) attitude toward visits. Families visit at anytime they please, and without a specific purpose which they are prepared to announce at once. Theoretically, they are to stay as along as they please. Thus, to ask "What can I do for you?" implies a desire to cut the visit short. Behaving in this way, Ocol alienates himself from his family and community. Okot is not here arguing that Africans dispense with European reckoning of time. Instead, he is showing that the clock is not being introduced where there is no concept of time. Rather, it is competing with established perceptions 
of time, and therefore causing disorder, confusion and disruption of very functional social patterns of behavior. A similar but more serious conflict which results from Western education pits traditional African religious beliefs against Western concepts of "superstition." Okot shows that traditional religion encompasses the community's whole way of life. Okot, through Lawino, explains the uses of specific forms of worship. Tribute to ancestors, for example, is one response to natural calamities such as famine, drought and death.

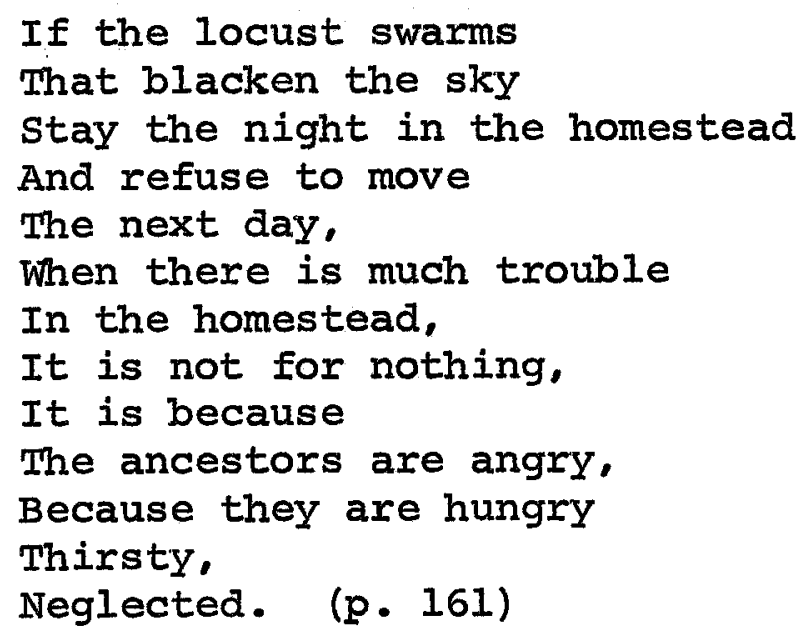

And when calamities of this nature face the whole clan, there has to be a cause. As Okot notes in Religion of the Central

\section{Luo:}

[An] abuse must have been done to the dead members of the clan, the ancestors, who have been neglected in the clan shrine and the whole community must gather to feed the ancestors and pray to the dead, for their 
troubles to be taken away by the setting sun. 21

This, with all other functions of traditional religion, is deplored by ocol. He forbids Lawino to consult the diviner priest for any purpose,

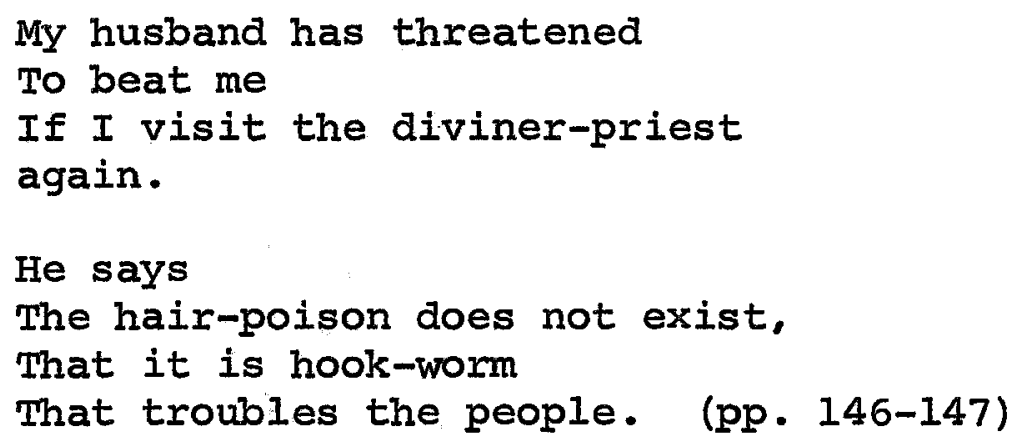

And in his total rejection of traditional religion as "superstition" he is even capable of sacrilege: Ocol

Once smashed up the rattle gourd, Cut open the drum

And chased away the diviner-priest From his late father's homestead. The old man walked away, His headgear waving His ankle bells jangling rhythmically And the large monkey-skin bag Dangling on his neck. (p. 150)

Furthermore, he

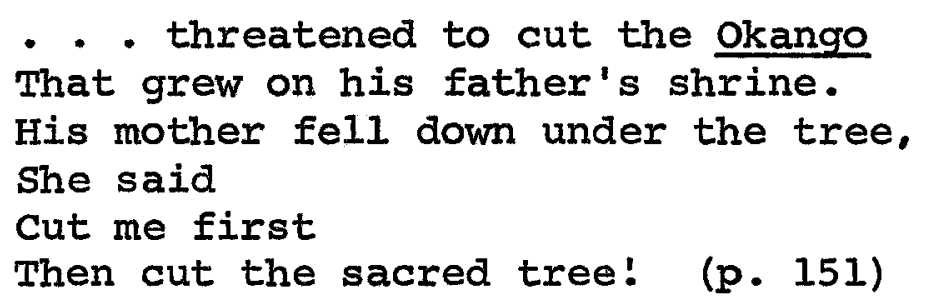

His opposition to magical charms does not apply to Christian 
ones:

My husband wears

A small crucifix

On his neck,

And all his daughters

wear rosaries.

But he prohibits me

From wearing the elephant tail necklace;

He once beat me

For wearing the toe of the edible rat

And the horn of the rhinoceros

And the jaw-bone of the

alligator. (p. 148)

Such passages imply that if Ocol were educated in the real

sense of the word, then he would be rational and examine the similarity between the two sorts of charms or two sorts of prayer.

Another detail of culture used to indicate Ocol's arbitrary attitude is naming practices. Some Acoli names are given to honor personality and status. Lawino explains:

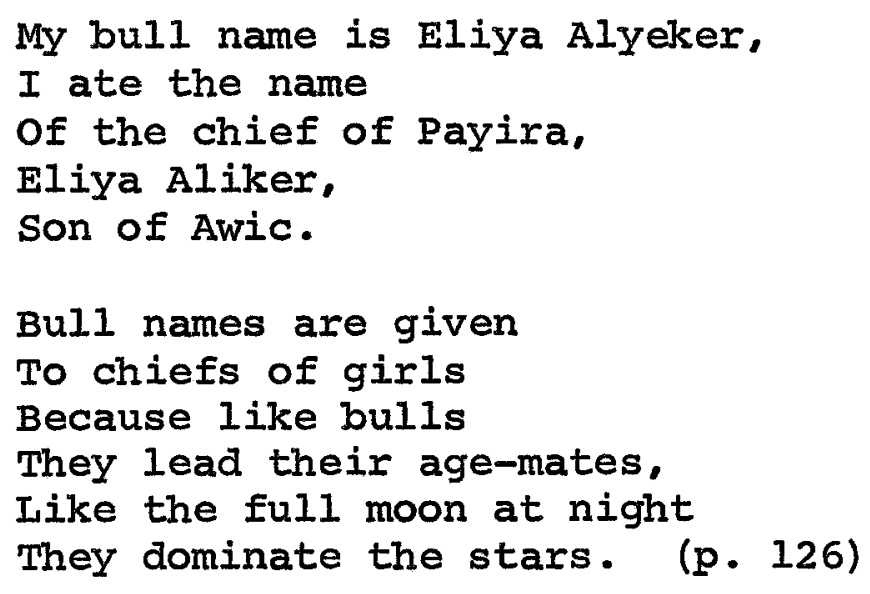

However, Ocol only approves Christian names: 
My husband rejects me

Because, he says

I have no Christian name. . .

My husband rejects Acoli names, Meaningful names,

Names that I can pronounce. (pp. 123-124)

A bigger issue is literacy. Ocol despises Lawino for being illiterate. In turn, Lawino finds too much reading to be seriously harmful, alienating and demasculating:

- Ocol has lost his head

In the forest of books.

When my husband

was still wooing me

His eyes were still alive,

His ears were still unblocked

Ocol had not yet become a fool

My friend was a man then!. . .

My husband has read much,

He has read extensively and deeply,

He has read among white men

And he is clever like whitemen.

And the reading

Has killed my man.

In the ways of his people

He has become a stump.

He abuses all things Acoli,

He says

The ways of black people

Are black

Because his eyeballs have exploded,

And he wears dark glasses,

My husband's house

Is a dark forest of books. (pp. 183-184)

In this and similar passages, Okot is not suggesting that

Africans should avoid schools and literacy. Instead he is 
rather realistically portraying some of the consequences

that the elite have experienced through excessive miseduca-

tion. As the critic, G. C. M. Mutiso, has summarized:

Through Lawino p'Bitek voices another of the concerns of many African writers, namely the fact that those Africans who were educated under British rule are now the ones who are most alienated from their tradition. Thus in the period of Independence and during the quest for cultural identity in terms of the nation and the continent, the educated are the ones who really have no culture or tradition to fall back on.22

Lawino's charge, however, goes further. She says

that Ocol and others like him have become "dogs of the white$\operatorname{man} . "$

-. You may not know this

You may not feel so.

But you behave like

A dog of the whiteman:

A good dog pleases its master,

It barks at night.

The dogs of whitemen

Are well trained

And they understand English!...

For all our young men

Were finished in the forest,

Their manhood was finished

In the classrooms.

Their testicles

Were smashed

With large books: (pp. 188-191)

${ }^{22}$ G. C. M. Mutiso, Socio-Political Thought in African Literature: Weusi (United Kingdom: The Macmillan Press, 1974), pp. 56-57. 
The claims of alienation through education are supported with many examples, especially examples from family tensions. Ocol disapproves of his mother's chewing tobacco. He will not entertain an uncle visiting without appointment. He has quarrelled with his brother despite their childhood closeness. He insults his wife and her parents. He is arrogant and abusive to all these relatives because Western education has alienated him from his culture at large, from his community, and even from his family. The novelist and critic, Ngugi wa Thiong'o, sums up the message of these passages:

What she (Lawino) is describing is the whole alienating effect of western education: people are educated not so that they may be re-integrated into the masses, help the community to raise their productive and cultural resources, join them in their struggle for total liberation, but to form a screen between the community and the objective reality. The poem is an incisive critique of the bourgeois mannerisms and colonial education and values. For it is Ocol's education, with the values it incalculates in him, that drives him away from the community.23

After defending the inherent strength and beauty of Acoli culture and after showing the destructive results of judging it by Western presumptions, okot goes on to demonstrate some faults, pretenses and follies of the Western ideals practiced in Africa. G. A. Heron has commented on

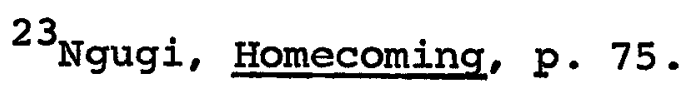


the value of this strategy:

These attacks on western ways are another reason for the popular success of the poem. They make the poem lively and readable and give the shock effect of a first reading.

Okot is making a number of very serious points through Lawino's mockery of westernised ways. At its mildest he is saying that the idea of 'progress' cannot be applied to culture. Ocol thinks that Acoli ways of dress, dance and religion are 'primitive' and must be superseded. But Lawino shows ways in which Western things can be dirty, stupid or hypocritical.24

As an example, to ridicule the Western devotion to sanitation, Okot has Lawino describe the local teacher, the West's paragon and emissary in the village. When he talked,

Saliva squirted from his mouth

And froth flew

Like white ants from his mouth, The smelly drops

Landed on our faces

Like heavily loaded houseflies

Fresh from a fresh excreta heap! (p. 117)

His clothes and body were unclean:

The collar of the teacher's white shirt

Was black with dirt,

He was sweating profusely

And his cheeks were rough

Like the tongue of the ox. (p. 118)

Furthermore,

The comb never touched his head,

His hair resembled the elephant grass,

${ }^{24}$ Heron, Introduction in Song of Lawino and Ocol. p. 21 . 
Tall and wiry

The teacher looked like a witch. (p. 118)

In short, the teacher's commitment to the West has diminished rather than increased his concern for hygiene.

More serious comments on Western practices are explicit or implicit throughout the song. Many are associated with Lawino's rival, clementine. For example, Lawino suspects her of practicing abortion (pp. 44-45), a Western innovation in a land where children are one's crowning glory. But Lawino most effectively demonstrates the harmful effect of Western influence by a sustained and detailed account of how missionary Christianity is hypocritical, oppressive and exploitative. Okot had already commented on this in African Religions in Western Scholarship:

The hostility of Christianity against the so-called pagans developed during the first three hundred years of its life, when the followers of Joshua, the Messiah (alias Jesus Christ) were subjected to bloody and cruel persecutions both at the hands of the Jews and the Romans . 25

Okot further shows that:

The victory of Christianity signified the decline of the ancient civilization of Rome with its religious tolerance. When Rome collapsed, the Christian church succeeded and superseded it. And it was upon the

${ }^{25}$ okot p'Bitek, African Religions in Western Scholarship (Nairobi: East African Literature Bureau, 1971), p. 25. 
foundation of the triumphant but intolerant Christian religion, which was most hostile to the so-called 'pagan' religions, that the world of the Middle Ages was slowly built on. 26

In Song of Lawino, these points are graphically portrayed in anecdotes regarding the lascivious, celibate priests, for example:

The teacher, still drunk.

He too is coming

To hunt for girls

At the 'get-stuck' dance!

He joined the line of youths

But they pushed him away!

He danced at the edge

Singing properly,

His large owl-head

Moving this way

And that way

To the rhythm of the drums.

Shameless

The ugly man

Whispered something in my ear:

And touched my breast

With the rough palm

of his bony hand.

cutting it as if with

An old rusty knife. (p. 122)

Not only is one teacher a hypocrite, but all of them:

And all the teachers

Are alike,

They have sharp eyes

For girls' full breasts;

Even the padres

Who are not allowed

To marry

$26_{\text {Ibid., p. } 31 .}$ 
Are troubled by health.

Even the fat-stomached

Who cannot see

His belly button

Feels better

When he touches

A girl's breasts,

And those who listen

To the confessions

Peep through the port-hole

And stab the breasts

With their glances. (p. 123)

On the oppressive folly of Western proclaimed sexual

mores, Okot had spoken at length in African Religions in

\section{Western Scholarship:}

In most African societies, having sexual intercourse with married women by persons other than their husbands is strictly forbidden; but unmarried women enjoy both unmarried and married men. . . For sex is good, and the joy of it goes far beyond its physical pleasures and outshines even the shame, which may be great, of breaking the bounds. It is important for African leaders to consider whether sexual ethics in their countries should be based on St. Paul's prejudices against women and sex, or built on the African view-point which takes sex as a good thing. 27

Lawino describes the result for adolescents:

The time when youth should meet youth

Is wasted in shouting things

No one understands,

Is spent in singing

Meaningless songs

That no one believes in.

The milk in your breast

Boils painfully.

${ }^{27}$ Ibid., pp. 116-117. 
Your breasts must be touched, Rubbed on the cool chest of your Beloved

So that the pricking pains May be relieved.

The heads of the young men Reject the pillows

And prefer

The arms of their lovers.

But they lock you up

Inside a cold hall

As if you are sheep.

And they lock up

All the girls

In one cold hall,

And the boys

In another cold hall.

And the young men

sleep alone

Cold, like knives

without handles. (pp. 120-121)

Here, Okot had in mind the missionary introduction of boarding schools, in which girls went to separate schools from those of boys.

As an example of the exploitation by missionaries, Lawino mentions the labour demanded of those studying to become Christians. In fact she claims she refused to join the catechist class rather than become a "slave." (p. 111) She describes the labour:

Oh how young girls Labour to buy a [Christian] name! You break your back Drawing water For the wives of the teachers, 
The skin of your hand Hardens and peels off Grinding millet and simsim. You hoe their fields, Split firewood,

You cut grass for thatching

And for starting fires You smear their floors With cow dung and black soil And harvest their crops. (pp. 111-112)

The missionaries even contrive to deny the girls adequate food. Instead:

- . when they [missionaries] are eating They send you to play games

To play the board game

Under the mango tree:

And girls gather

Wild sweet potatoes

And eat them raw

As if there is famine,

And they are so thin

They look like

Cattle that have dysentery! (p. 112)

Meanwhile, the church makes such excessive demands for money that Lawino is impelled to ask:

Do they buy the places

In skyland with money? (p. 130)

These serious charges are relieved by an aside on the Christian names, hard-won but meaningless and unpronounceable to their new bearers. This is illustrated by Lawino's own renderings. For 'Jackson' she says 'Jeckon,' for 'Francis,' 'Paraciko,' for 'Thompson,' 'Tomcon,' for 'Erik,' 'Iriko.' Lawino even exposes irrationalities in Christian 
mythology and theology by recounting the missionaries' frustration and hostility when they are asked innocent but incisive questions (pp. 131-132). Such passages reveal insecure, superficial teachers whose doctrines will not bear examination.

With this extensive comment on Christ's representatives, Lawino reaches her climatic defense of Acoli culture and attack on Western influence. The song as a whole by its wide ranging themes portrays the aesthetic and moral strength of her own tradition and contrasts it with the hollow falsity of the Western beliefs and values as they are presented in her homeland. Above all, the song undermines any Western claim to cultural, aesthetic or moral superiority. The expansive range of topics and the dramatic realism with which they are treated help to account for the work's unique popularity

After this attack on cultural colonialism, Okot turned to its consequences and manifestations after political independence. The first of these songs is Ocol's response to Lawino's case. To the Song of Ocol we turn next. Many critics agree with G. A. Heron's saying that "Song of Lawino and Song of Ocol are not the thesis and antithesis of the argument and that if song of Ocol is a 
reply to song of Lawino, then it is a bad one." True, Song of Ocol does not represent a concrete, fair rejoinder to Lawino's argument; on the contrary, Ocol confirms some of Lawino's assertions in Song of Lawino. In Song of Ocol. Okot endeavors to further elaborate the harmful effects of Western education as already presented through song of Lawino. The evil effects of Western education conclude the elites' hatred for their own African continent, the Black African community, their families and, worse of all, hatred for and alienation from themselves. They are ashamed to be Black. They are also ashamed of their customs. Okot presents the protagonist and speaker of Song of Ocol as a typical product of such an education. Ocol condemns all Africans. They are primitive and children in Ocol's view:

Child,

Iover of toys, Look at his toy weapons, His utensils, hit hut ... Toy garden, toy chickens, Toy cattle, Toy children . . .

Timid, Unadventurous, scared of the unbeaten track, .. . Unweaned, clinging to mother's milkless breasts clinging to brother, 
To uncle, to clan,

To tribe

To blackness

To Africa, (pp. 207-208)

As a result, ocol is ashamed of himself and wants to deny his africanity. To show that Okot is against Ocol's views, Okot plants words and ideas in Ocol which make Ocol condemn himself without realizing that he is doing so. Okot presents 0 col ironically, and makes him talk in a satirical manner. In being satirical, Ocol thinks that he is ridiculing and making fun of the Africans, their customs, and their continent. However, while ocol is being satirical, the readers find out that in fact he is unconsciously condemning himself. We may observe this technique by evaluating several assertions which Ocol makes.

The type of education that ocol received from the missionary schools has taught him hatred for his own continent.

What is Africa

To me?

Blackness,

Deep, deep fathomless

Darkness ;

Africa

Idle giant

Basking in the sun

sleeping, snoring,

Twitching in dreams; (p. 206) 
Ocol is also ashamed of his colour and therefore of his origin.

$$
\begin{aligned}
& \text { Mother, mother, } \\
& \text { Why, } \\
& \text { Why was I born } \\
& \text { Black? (p. 208) }
\end{aligned}
$$

He is ashamed of everything African including all African customs. In Song of Lawino, Lawino asserted that Ocol condemns all African religious practices and traditional medicine, and feels that he is responding to them as an "educated" man and a Christian.

Ocol's condemnation of all traditional medicine is confirmed in Song of Ocol, when he briefly but unpleasantly comments on traditional medicine. Here again, one notices how Okot plants false statements about African medicine in order to demonstrate that those Africans who insist on blindly following Western ways are foolish because they misunderstand their own ways and therefore they do not know themselves. For example, Ocol offers us an incredible impossible scene of traditional medicine being practiced:

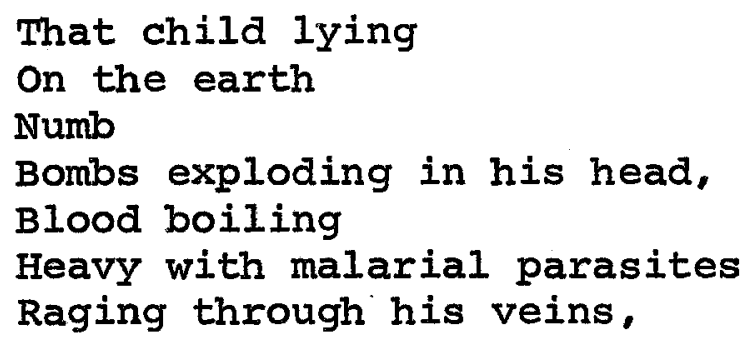


The mad woman

Spits on the palms

of his hands

And on his feet,

Squirts beet

on his face

To cool him,

Spills chicken blood

On his chest,

A gift of Death: (p. 212)

The false pictue, skillfully displays Ocol's misunderstanding of African medicines. Lawino gave a detailed description of the different roots, leaves or, in general, vegetation which provide different medicines for treating various diseases. Ocol appears not to be aware of any of those. Okot in many instances like this exposes Ocol's ignorance of truth about his continent and community.

Ocol further mocks the traditional treatment of African women.

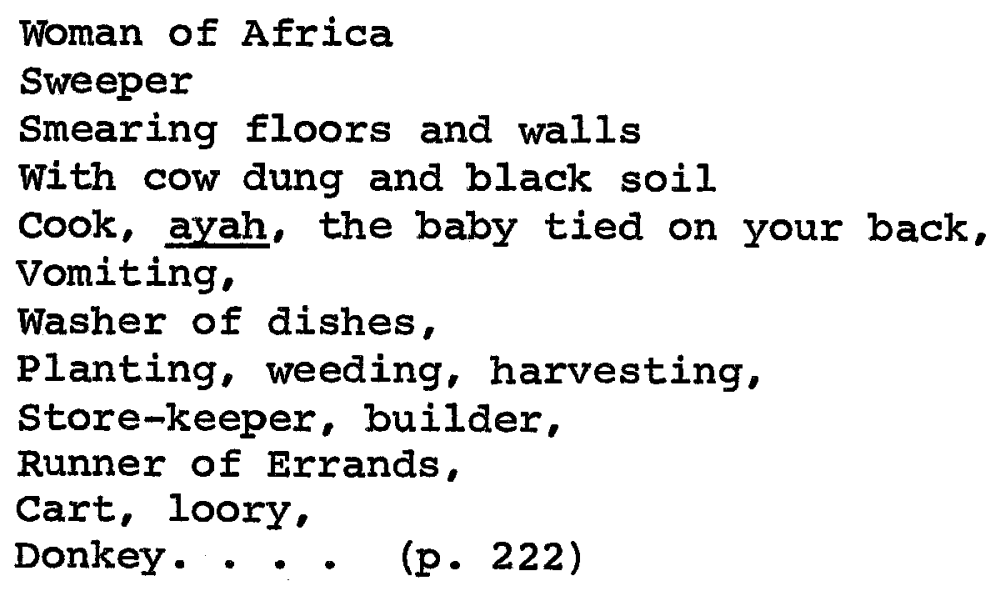

There is much truth in this accusation, but again okot plants in misrepresentation and exaggeration. The final and false 
hyperbole that women are used as lorries, carts and donkeys casts a serious doubt over whatever in the charges seems warranted.

Ocol also states that sometimes the status of women even is lower and gives certain instances as examples:

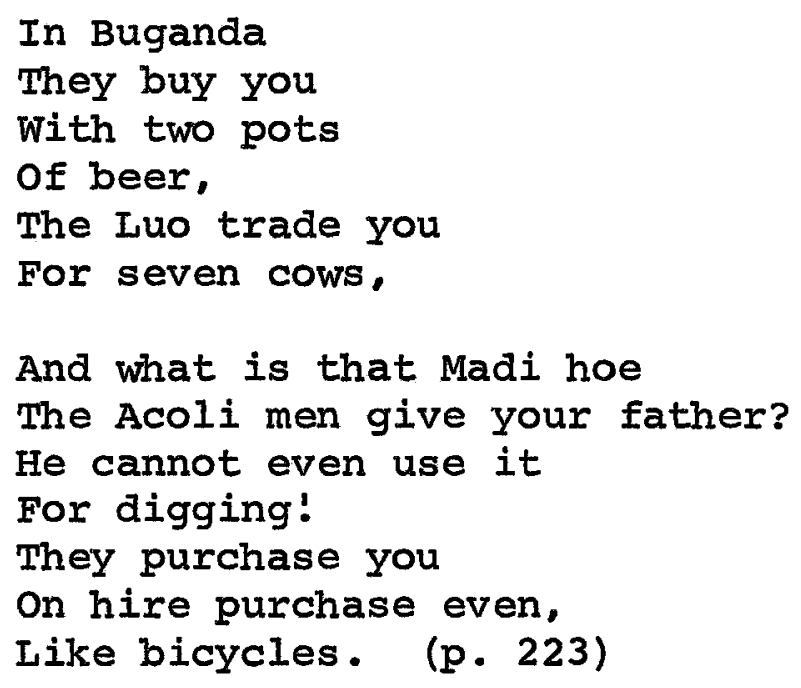

No serious opponents of the custom of bride-price would concur in such an over-simplified attack as this one. Ocol here as usual is unconsciously displaying his own folly as well as his ignorance of the significance of bride-price in African communities.

Ocol further describes a hopeless improverishment of pastoral communities of East Africa such as the Karamojong, the Masai, Suk, Kipsigis, Kalenjin and Luo. Ocol's ignorance of the fact that these tribes are relatively prosperous shows that Okot disagrees with many of the conclusions reached by Ocol. Ocol ridicules all the Africanity that Lawino praised 
and rejoiced in. Ocol and his counterparts wish to eradicate the whole African past, as well as all the customs such as circumcision.

Once again, we may see how Okot puts words in ocol's mouth, to show Ocol's shortsightedness:

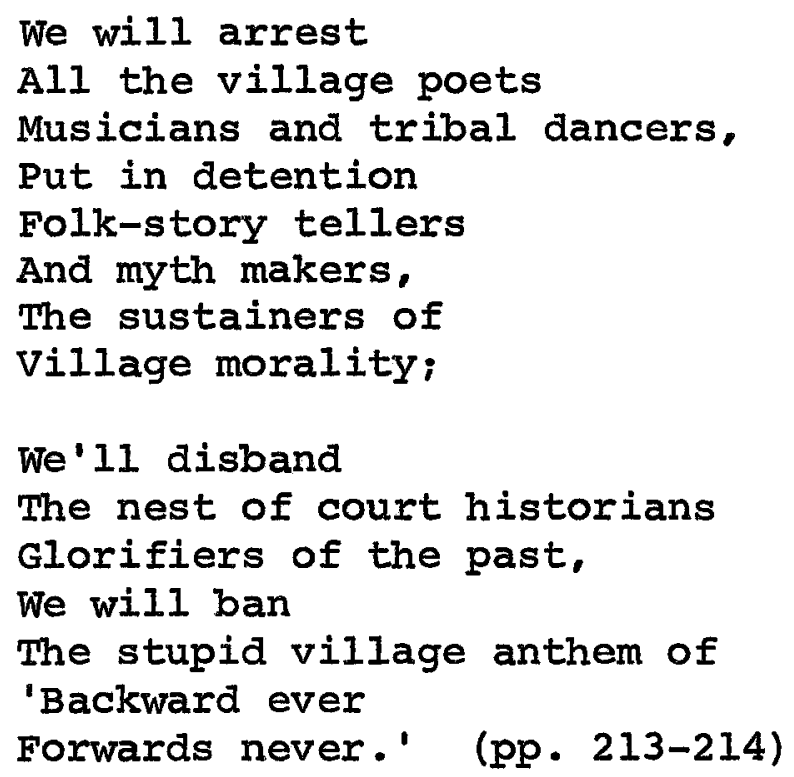

Obviously, it is unreasonable to critically reject all African past. Ocol even rejects a Western oriented study of African culture, lest it remind him of the Black African past. Okot regards such reminders as an ill effect of Western education. People are educated in order to "be brainwashed" and hate themselves. In Ocol's plan for the future of Africa, all African educators will be destroyed. These include "all the professors of anthropology, and teachers of African history." (p. 215) In essence, "all the schools of African studies" (p. 213) will be closed down. Ocol condemns and rejects 
all efforts not only to find reasons for meaningful pride in African past, but even to mention anything African. He is essentially destructive and he would rather destroy and forget his African past than be tormented by the spirit of the African past. Therefore, Ocol cries out pitifully but contemptibly:

Smash all these mirrors That I may not see The blackness of the past From which I came Reflected in them. (p. 215)

and:

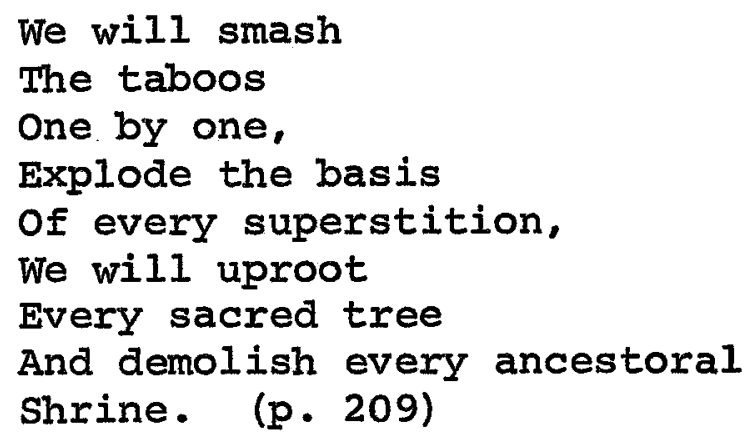

Ocol's hatred of his African self and therefore his hatred for his continent, Africa, further leads to his desire to destroy its nature:

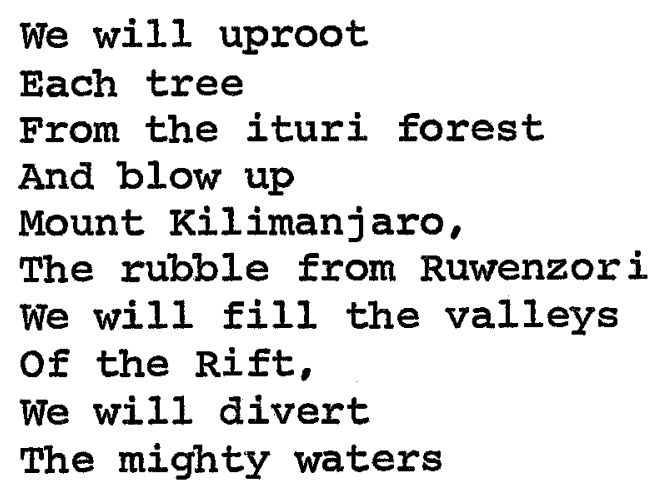


Of the Nile

Into the Indian Ocean. (p. 245)

The irrationality with which ocol presents his condemnation of the Blackness of Africa, the hopeless impoverishment of the East African pastoral communities, and the measures to be taken to destroy all African images, is evidence of okot's disagreement with Ocol on these issues.

Having described the measures that will be undertaken to eradicate the Black African image as it were, Ocol anticipates the future of Africa. Ocol has strong feelings that the "pumpkin" will be destroyed, and was in fact on its way to being destroyed:

I see an old Homestead

In the Valley below

Huts, granaries . .

All in ruins;

I see a large pumpkin

Rotting

A thousand beetles

In it;

We will plough up

All the Valley,

Make compost of the Pumpkins

And the other native vegetables,

The fence dividing

Family holdings

will be torn down,

We will uproot

The trees demarcating

The land of clan from clan.

We will obliterate

Tribal boundaries 
And throttle native tongues

To dumb death. (pp. 204-205)

Ocol addresses Lawino's clansmen and Lawino to bid farewell to their village and customs:

Let the drummers

Play the rhythms

of the funeral dance,

And let the people sing and dance

And celebrate the passing of

The old Homestead! (p. 247)

Ocol is sure that he has succeeded in destroying the African past whose admirers mourn:

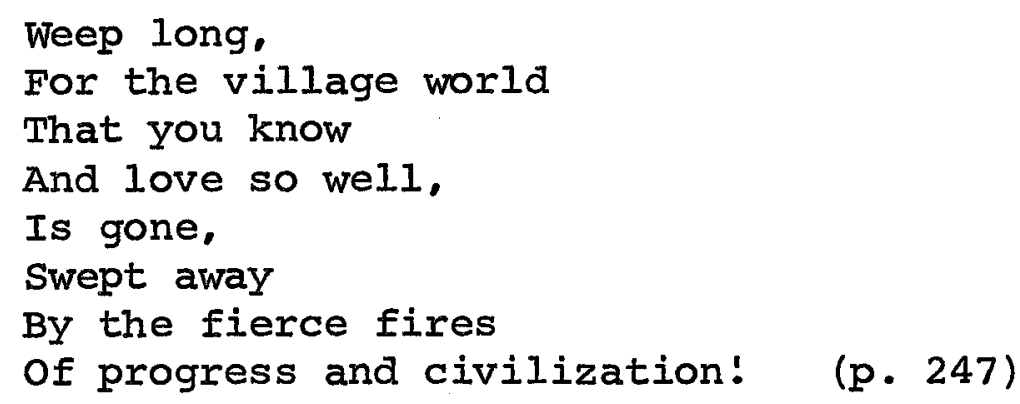

However, he suggests that they will not only mourn, but they will be celebrating the "new age" of development, growth improvement and advancement both in culture and in education, as a result of adopting Western ways.

Let the people drink

Kwete beer and Waragi

Let them suck Lacoi beer

With the sucking tubes

As they mourn

The death of

The old Homestead:

You village chief

sitting on the stool

And leaning on the central pole 
of your hut,

Say goodbye [to the African past]

(pp. 248-249)

In the final analysis it is evident that "progress and civilization" have both overwhelmed and replaced the African past; therefore Ocol tells Lawino that there are only two options left for her, to adopt the new life. If not she should kill herself.

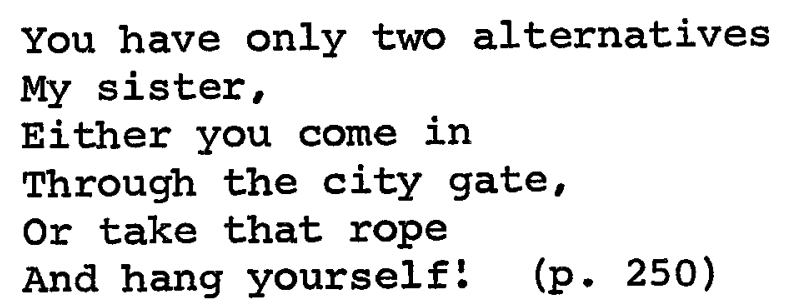

Consequently, Western city life takes over the village life. In the final part of Song of ocol, the city is barely described, within which monuments will be named after its founders: "Leopold of Belgium, and Bismarck." As for the streets, they will be named after the European explorers in Africa:

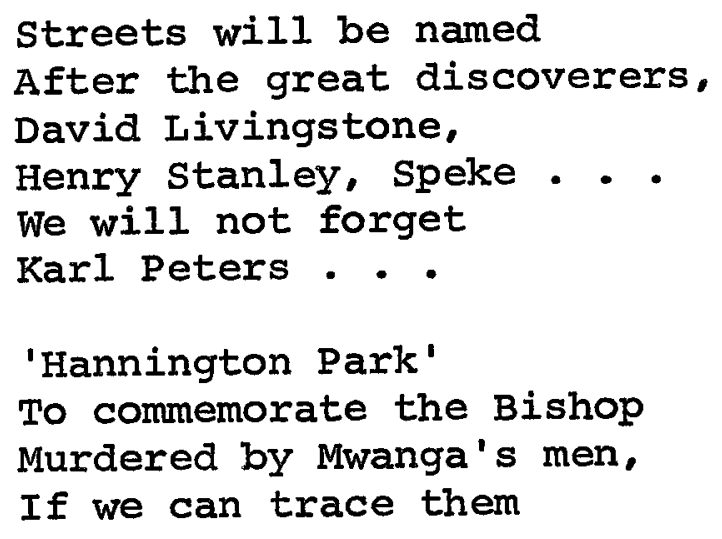


We'Il hang them

For the crime. (p. 254)

Notice the way okot puts words into Ocol's mouth to show that he grants no single credit for anything African. According to Ocol, all the great men of Africa are not in fact great because they were defeated; and they are "irrelevant":

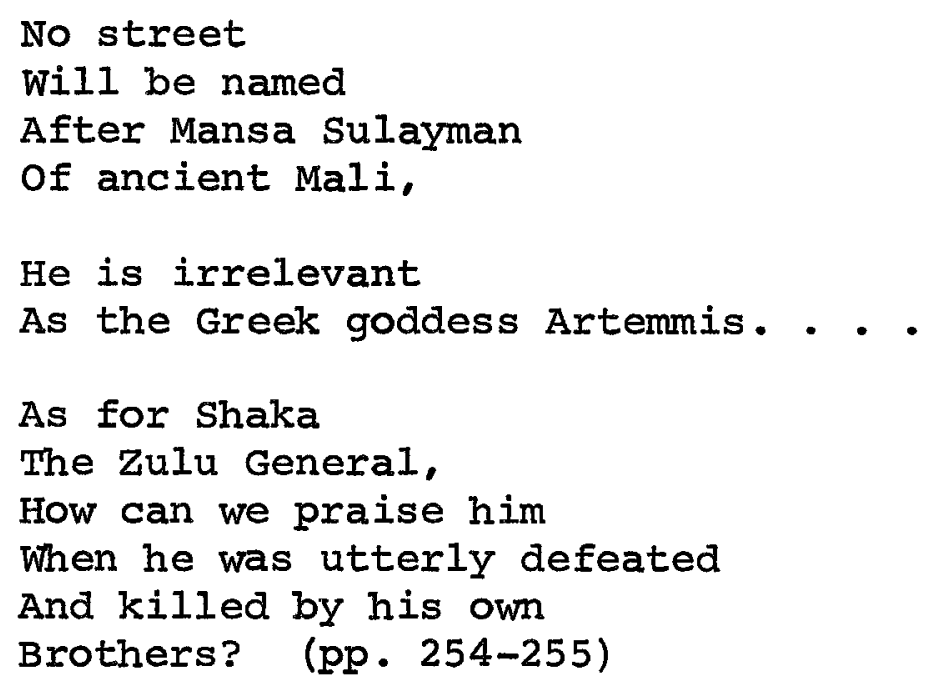

The above issues in Song of Ocol, emanating from the ill effects of Western education, were dealt with in one way or another in Song of Lawino; however, they are broadened here. Okot also elaborately deals with the question of political ills at length in Song of Ocol.

The post independence political status of the East African countries in particular, but of the African countries at large, is a major preoccupation in song of Ocol. In Song of Lawino, okot lightly touched this political issue, when he demonstrated how politics had destroyed the unity of ocol's 
home. Ocol was in conflict with his brother, owing to Ocol's political activity. In Song of Ocol, Okot criticizes the dictatorship, capitalist and discriminatory kind of government established by Africans themselves after gaining independence from foreign rule.

The governments are discriminatory in nature because they are conducted by an elite for its own capitalist advantage. The elite's alienation from the community is symbolized by the use of foreign titles and foreign languages.

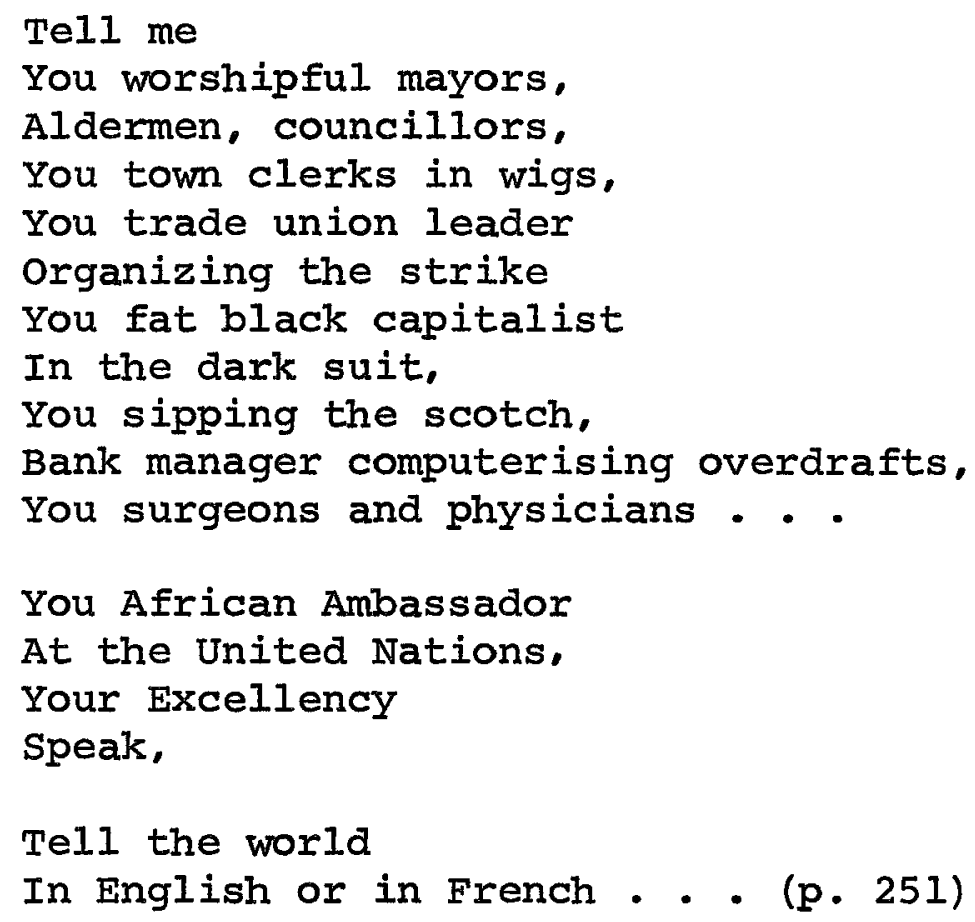

Okot's ideology on the nature of politics in African countries is observed in his article entitled "Indigenous Ills." He criticises discrimination, dictatorship and capitalism of African countries in this article. Specifically, regarding 
the role of education, he says:

The most striking and frightening characteristic of all African governments is this, that without an exception all of them are dictatorships, and practice such ruthless discriminations as make the south African apartheid look tame. African socialism may be defined as the government of the people by the educated, for the educated. You cannot become a member of their parliament unless you can speak English or French or Kiswahili. You may be the greatest oral historian but they will never allow you any where near their university.

This is not discrimination by white settlers against Africans, but discrimination of Africans by Africans, discrimination by the 'black-suit' town tribesmen, discrimination by the educated men in power against their fellow men-their brothers and sisters, mothers and fathers, against their own folk left in the village. 28

One point which okot makes in Song of Ocol as well as in "Indigenous Ills" is that the Africans are not satisfied even under their own fellow black rulers who took over after foreign rule. The black rulers just stepped in the "shoes" or footsteps of their predecessors, the foreign rulers. The African masses fought for freedom, but now they are neither appreciated nor compensated. Instead, Black rulers do not recognise the efforts of the voters to achieve freedom. Ocol speaking for such presidents even maintains that the masses did not do much.

28 okot p'Bitek, "Indigenous ills," Transition: A Journal of the Arts, Culture and Society 7:32 (August/ September 1967) : 47 . 
We spent years

In detention

Suffering without bitterness

And planning for a revolution;

Tel1 me

My friend and comrade,

Answer me simply and frankly.

Apart from the two shillings fee

For Party membership.

And the dances you performed

When the party chiefs

Visited your village,

And the slogans you shouted

That you did not understand,

What was your contribution

In the struggle for Uhuru? (pp. 232-233)

Ngugi wa Thiong'o in Petals of Blood hails the same notion.

This was the society they were building: this was the society they had been building since independence, a society in which a black few, allied to other interests from Europe, would continue the colonial game of robbing others of their sweat, denying them the right to grow to full flowers in air and sunlight. 29

Similarly, Ocol as the president sees no reason to do anything for the citizens who put him in power. Instead, Ocol is self-centered and demands compensation for being a politician:

And, surely

You are not so mean

As to grudge them

${ }^{29}$ Ngugi wa Thiong'o, Petals of Blood (New York: E. P. Dutton Publishing Company, 1977), p. 294 . 
Some token reward, Are you? (p. 233)

The issue in the above quote refers to those Black African leaders who took over political position from white or foreign rule. Okot is mocking those African politicians who enjoy wealth at the expense of the masses with the excuse that they (those African politicians holding power) fought for freedom and not the masses. Consequently, such politicians lead a luxurious life in their beautiful homes. In Ocol's satirical words: "Do you see/That golden carpet covering the hillside? Those are my sheep." (p. 135) And:

I have a nice house

In the Town

My spacious garden

Explodes with jacaranda and roses, I have lilies, bougainvillea, canna . .

Do you appreciate the beauty

of my roses?

Or would you rather turn

My flower garden

Into a maize Shamba? (pp. 233-235)

We may notice how Okot plants in these words an argument against Ocol. Ocol condemns himself without realizing it. Okot here is critical of the capitalistic nature of African government, and therefore the society. The politician is just amassing wealth, instead of helping his citizens solve their problems of poverty and other ills. Okot has in mind the same idea which he had in "Indigenous Ills" when he 
criticized the African university students' capitalistic objectives :

The students in our university are not revolutionary. They are committed and conservative. They have vested interests. They look forward to graduation, the circumcision ceremony before joining the 'big car' tribesmen. Our university and schools are nests in which black exploiters are hatched and bred, at the expense of the tax payers, or perhaps heartpayers. 30

The same case in Okot's view applies to politicians such as Ocol. As a president Ocol is unconsiderate of the masses and only interested in bettering his life. As a president one's duty is to try, at least, to satisfy the necessary needs of the masses. He should try to make them comfortable. But here is Ocol as a president who does not accept the responsibility of the suffering of the masses who voted for him:

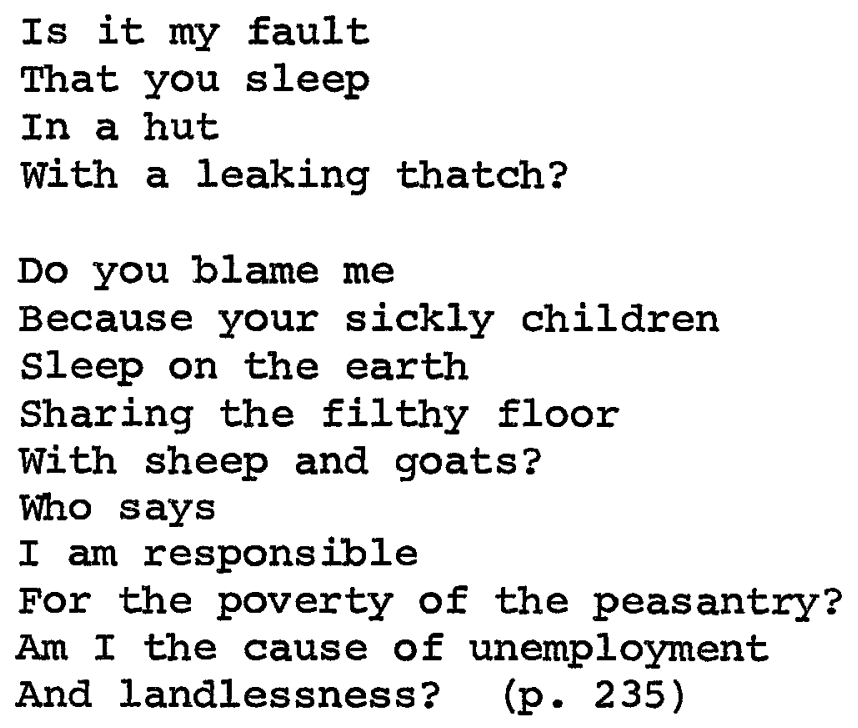


Okot is concerned with the Black African political leaders who are rich at the expense of the masses:
And when they have fallen into things They eat the meat from the chest of bulls And their wives grow larger buttocks And their skins shine with health, They throw themselves into soft beds But the hip bones of the voters Grow painful sleeping on the same earth They slept [on] before Uhuru. 31

The issue being discussed is that the voters expected change for the better after foreign rule was dethroned. But they have experienced no beneficial change because they are still suffering as of old:

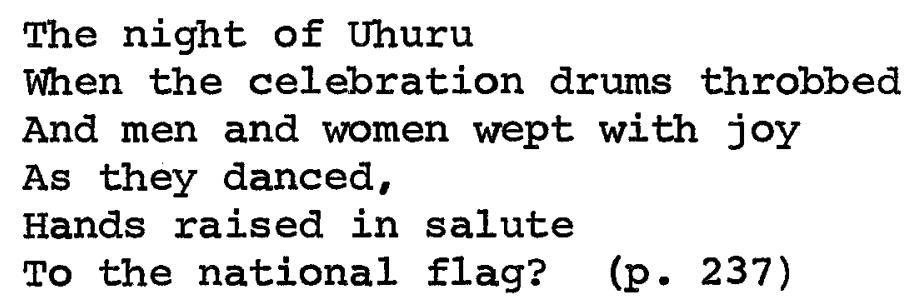

Okot is against the oppressive type of government in which Black African leaders do not exercise equality and justice to the citizens. As he puts it in "Indigenous Ills":

I leave to the political scientists to explore and analyse this strange situation, whereby independence means the replacement of foreign rule by native dictatorship. What does equality mean in newly independent African states? ${ }^{32}$

Okot's intention is that African governments should strive for justice and democracy in the future. 
Ultimately, one can say that in Song of Ocol, Okot is challenging the African elite, the post independent African political leaders, and the African scholars. To the African members of the elite who were brainwashed by the Western education, Okot is mocking their unreasonableness in blindly taking up values which teach them self-hatred and hatred for their own continent. Okot is challenging the African political leaders to strive for political justice. As for the African scholars, Okot challenges them to reassess the ideology on which African societies are to be based.

$$
\begin{aligned}
& \text { You scholar seeking after truth } \\
& \text { I see the top } \\
& \text { of your bald head } \\
& \text { Between mountains of books } \\
& \text { Gleaming with sweat, } \\
& \text { Can you explain } \\
& \text { The African philosophy } \\
& \text { On which we are reconstructing } \\
& \text { Our new societies? (p. 252) }
\end{aligned}
$$

In this chapter we are mainly concerned with ideas in Song of Lawino and Song of Ocol. Okot addresses the Western values versus traditional values in song of Lawino. Here, he portrays the inherent strength and structure of traditional society. And in contrast, he exposes the falsity of Western society's claim to be superior, especially the claims of Christianity. He conveys the ill effects of Christianity on African societies. Further, Okot 
preoccupies himself with the harmful effects of Western values on African societies in general, but on East African societies in particular, in both song of Lawino and song of Ocol. The ill effects of Western education result in selfhatred in African elites. Consequently, African elites become destructive of their own culture, and want to replace it with western values. Okot moves from matters of taste and education concern to the political concern in Song of Ocol. Here, he critizes the fact that independence in post independent African societies means dictatorship, capitalism, discrimination, and hence no equality among citizens. His implied solution is that Africans should strive for political justice.

In the next chapter, we will see that Okot shifts his attention from the social concerns of African versus Western theme. He develops the political theme with more detail and expands it to include a celebration of folklife anywhere. In this way, one can see the consistencies and developments in Okot's poetry over a period of five most important years. 
CHAPTER III

\section{THEMES IN "SONG OF A PRISONER"}

AND "SONG OF MALAYA"

Song of A Prisoner ${ }^{1}$ was first published in 1970. In 1971 it was published again in a combined edition with song of Malaya. ${ }^{2}$ The "two songs" are independent works although they have many things in common. For example, each is a dramatic monologue like the "songs" of Lawino and Ocol, and each is short compared to the former songs. Both are devoted to African societies after independence. They use as speaker a prisoner and a prostitute, respectively, to comment on African social and political ills. ("Malaya" is a Swahili word meaning "prostitute.") However, these two songs are sufficiently different to require separate discussions. This chapter will discuss the themes of each in turn.

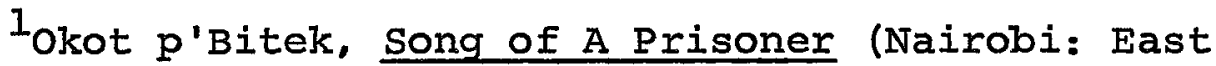
African Publishing House, 1970).

2 Idem, Two Songs (Nairobi: East African Publishing House, 1971). 
Song of A Prisoner is thought by some critics to be Okot's finest writing to date. His major concern is an overview of the political ills in post independent African countries. This political orientation is first indicated in the dedication to African political leaders who were assassinated early in their careers. This is not the first time that okot has indicated his political concerns in the songs. Lawino pointed out some harmful consequences of political parties, particularly their destructive influence on family and home. In Song of Ocol, Okot extended his comments on Africa's political situation. By ironical implication, he attacked the post independent African political leaders' betrayal of the hopes of freedom.

But Song of A Prisoner represents his first comprehensive political statement. The statement is so impassioned that Edward Blishen sees it as a poem about okot himself. who feels himself to be "the proud Eagle that has been shot down by the arrow of Uhuru." 3

Okot's basic political views are that the hopes of freedom have not been fulfilled and that the post independent African leaders simply stepped in their predecessors'

3 Edward Blishen, Introduction in Song of A Prisoner by Okot p'Bitek (New York: Joseph Okpaku Publishing Co., 1971), p. 38 . 
(Western colonialists) shoes. Consequently, Okot attempts to show in Song of A Prisoner that the African people in post independent times are still frustrated, despite their being ruled by their own people. However, Blishen lays the blame on the colonialists:

- . given the disorder which colonialism brought to Africa, given the disorder in which it quitted Africa, it will take patience and nerve to rebuild African stability, and to repair what has been broken. 4

Okot conveys his political views through an intensely dramatic form. The song is sung by a prisoner, but in order to cover the range of ideas and feelings, the prisoner is a composite of two prisoners, each with his own history, crime and concerns.

The first ten sections are devoted to one prisoner who is called "a vagrant, a loiterer," ${ }^{5}$ although he is not sure why people call him this. He has been a footballer, a boxer, a hunter and a dancer. His father is dead. (pp. 4748)

More importantly, he was imprisoned because he assassinated a political leader:

${ }^{4}$ Ibia., p. 37 .

${ }^{5}$ Okot p'Bitek, Song of A Prisoner (New York: Joseph Okpaku Publishing Co., 1971), p. 46. All subsequent references to the poem will be cited in the text by page number from this edition. 
Yes.

I did it

And,

My God,

What a beautiful

Shot:

I scattered

His stupid brain

Into a thousand drops,

His proud body slumped

And soiled our land

With his rotten blood! (p. 79)

He has a home in the village, where he has a wife, possibly seduced by a rich man with "a black Benz." (p. 64) His children who also live in the villages suffer from hunger, and hence possibly Kwashiokor. The family sleeps in "an old hut with a leaking thatch." (p. 76) His children can neither go to school nor hope to find employment. (pp. 106-107)

This prisoner imagines his family to be involved in his suffering. He is then mentally tortured by mixing his troubles with their pathetic life. He is very responsible and has hopes for his family's future. Therefore he imagines that he has bought a farm for his wife and children.

My love,

Sleep for the last time

In that old hut

With the leaking thatch,

sleep for the last time

on that dirty papyrus mat

on the earth, 
I have bought

A farm

In the fertile valley,

A thousand acres

of heaven

For you and me

And my children (pp. 76-77)

Finally he seeks to dance and forget his suffering, frustration, hopelessness, and the fact that "his children will

never go to school and they will never get a job." (p. 109)

Another prisoner with a totally different biography

emerges in sections eleven and twelve. He is a former

minister who was arrested owing to the political quarrel

within the cabinet.

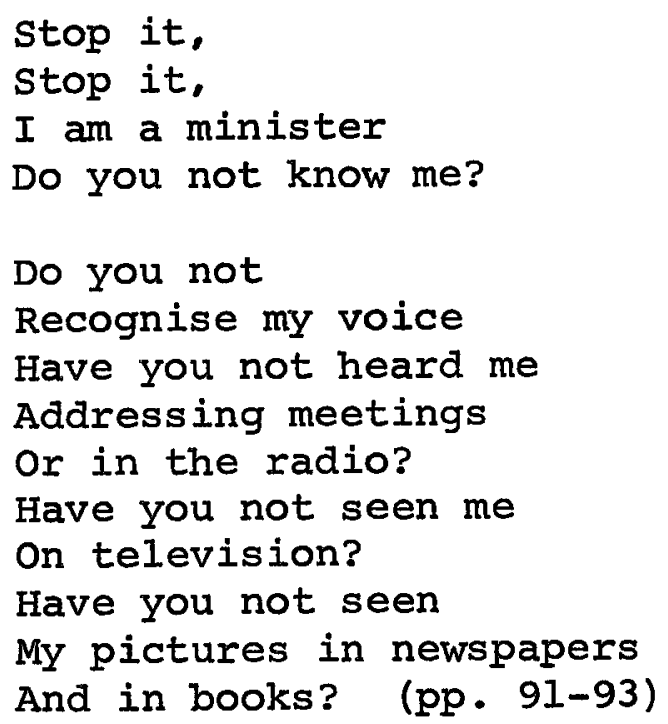

The prisoner as a minister has a totally different biography from the vagrant. For example, both his parents are alive, unlike the vagrant's father, who is dead. His parents seem to be used to getting cheques from him. 
Where is my writing pad?

I want to write

To my parents,

I want to send a fat cheque

To my old mother

And another fat cheque

To my old father...

But how can I tell them

That I am shoeless,

That my feet are swollen,

Blistered and bleeding?

How can I tell

My mother that I am

Naked and bruised

All over?

I do not want

My mother to kill herself,

I do not want

My father to die

of a heart attack... (p. 98)

The minister's children are both at school, unlike the vagrant's.

Where is my gold pen?

I want to write letters

To my children

And send them money,

I will not tell them

I am here,

I don't want them

To know that I am

A prisoner,

I want them to grow up

Without suffering,

I want them to pass

Their examinations

And get good jobs

And buy land.

Houses,

Cars . . (pp. 96-97

Because Okot wishes to view the society in a holistic manner, rather than from the limited perspective of one individual, 
he combines these two separate biographies into one "Prisoner," one figure who represents all those who end up in prison because of society's inequities. This is most clearly evidenced in the last two sections (14, 15), which could be the words of both the prisoners or either one of them. Therefore we will usually speak of the prisoners as though there were only one. This will conform to Okot's poetic intent, which was to have a single dramatic persona and situation. All the sections of the poem include the same pathos and the same rhetorical strength associated with both prisoners. Furthermore, the unifying single dramatic situation is emphasized by the following stanza, which is repeated several times throughout the poem.

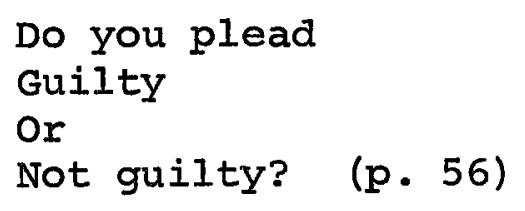

In response to the above question, the composite prisoner displays rage, anger, hatred, frustration and pride on one level, and on another he pleads hunger, fear, smallness, helplessness and drunkenness.

Unity of the poem is also based on the implication throughout the poem that the real issue is the disordered society rather than the prisoner's own particular "crime." Society is the true criminal. For instance, when questioned 
whether he pleads guilty or not, the prisoner says:

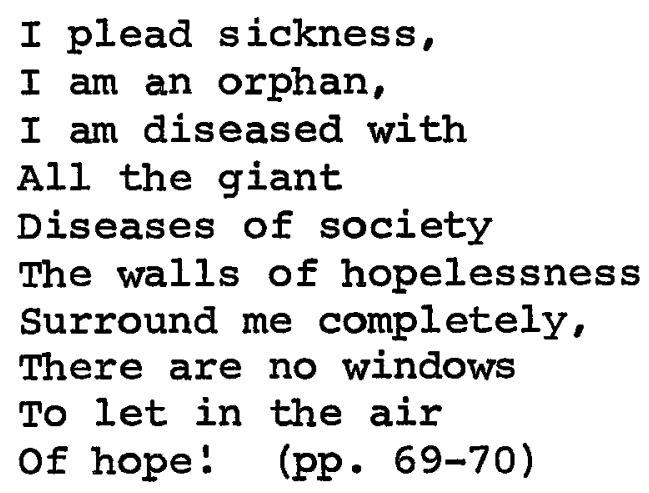

Such questions as "what is the crime, and who is the criminal?" can be seen in the vague and ambiguous statements of the charges and in the self-justification of the composite prisoner. For example, the prisoner admits that he killed the political leader, although not for money:

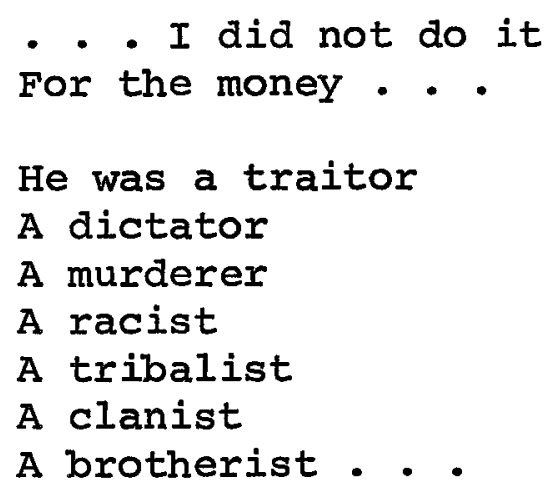

The prisoner further justifies his deed:

I had to kill him, And I did it kindly, 
He did not suffer long

He died instantly!

He was arrogant

And your beauty spurred him on,

His words were swords,

Heads rolled when he spoke . . (p. 84)

In contrast, the prisoner reveals the crimes he and

his people have suffered and are still suffering. These include poverty of his family, e.g., his "children have mosquito legs," (p. 50) because they cannot afford food to eat. The prisoner's family and village clansmen are mentioned in every section except the last one. The prisoner imagines them (family, wife, clansmen, etc.) to be involved in his suffering, by transferring his pain to them.

My mother slashes

The wall of the black sky

With her ululation,

My sister mumbles a dirge

And rolls herself

In the dust, (p. 54)

Here, apparently his mother's and sister's suffering comes about because of the prisoner's torture. In other instances the prisoner's torture is heightened by his family's suffering.

The cry of my children

And the sobs

of my wife

Haunt me like

A vengeful ghost, 
The fiery lips

of my sister's song

Burn me like leprosy,

The hammer of my mother's

Helpless ululation

Bashes my brain... (pp. 57-58)

The prisoner himself is in a bad state. He is beaten, tortured and refused a blessing. He is punished even before he pleads guilty.

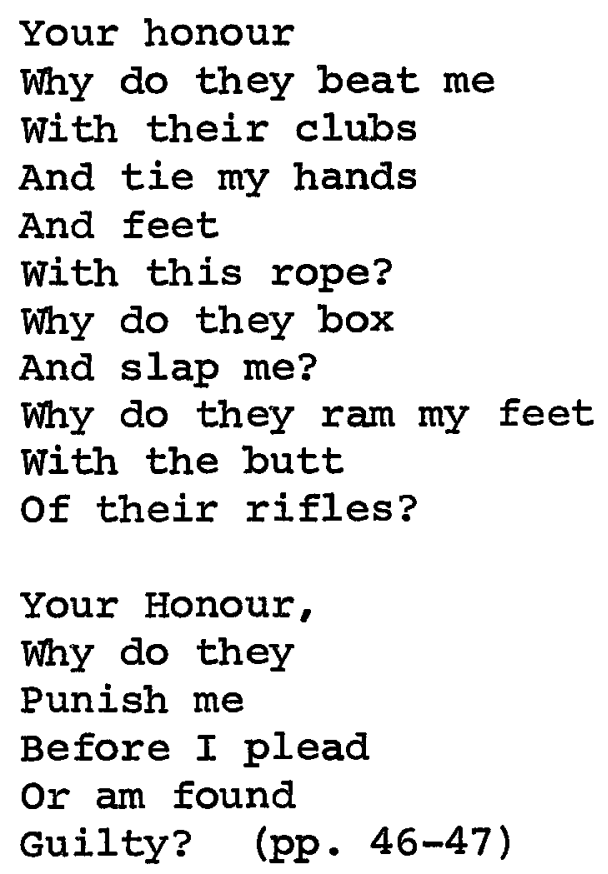

Here the prisoner is tortured physically. However as the poem progresses his mental torture is even more significant. His frustration is worsened when he imagines his wife having an affair with a "Big Chief" who owns a Mercedes or "a black Benz." (pp. 64-66)

My bed yells

In rhythm, woman giggles And shrieks 
In sweet agony . -

Man breathes heavily,

Bathes in sticky sweat

And hides his shameless face

Between the large breasts

of my woman...

Big Chief

Is dancing my wife

And cracking

My sacred rock: (pp. 65-66)

The prisoner is referring to a type of corruption

whereby poor folks generally are exploited by the rich or the elite. The richman apparently succeeds in seducing the prisoner's wife by means of his riches. Some critics have misunderstood the above passage. To borrow G. A. Heron's words :

Margaret Marshment, in her summary biography of the prisoner, takes the seduction of the vagrant's wife by the Big Chief as a fact from the vagrant's past, but if it has just happened it is difficult to see how he can know about it and if it happened before his imprisonment it should be described in the past tense. 6

Hence it should correctly be thought of as the prisoner's imagination through which okot attempts to make a certain point about corruption.

The theme of corruption is extended in sections four and six, entitled "Bonfire" and "This Stupid Bitch,"

${ }^{6}$ G. A. Heron, The Poetry of Okot p'Bitek (London: Cox and Wyman Press, 1976), p. 82. 
respectively, where okot is critical of Tribalism. In "Bonfire," the prisoner facetiously blames his father for wrong choice of wife:

Why did you vote

For this silly girl

To be my mother?

You should have known

The Tribe and the Clan

In which the most intelligent

Hardworking,

Thrifty

Ruthless

And most successful Chiefs

Are born and bred . . . (pp. 59-60)

Similarly in "This Stupid Bitch," the prisoner blames his mother for wrong choice of husband:

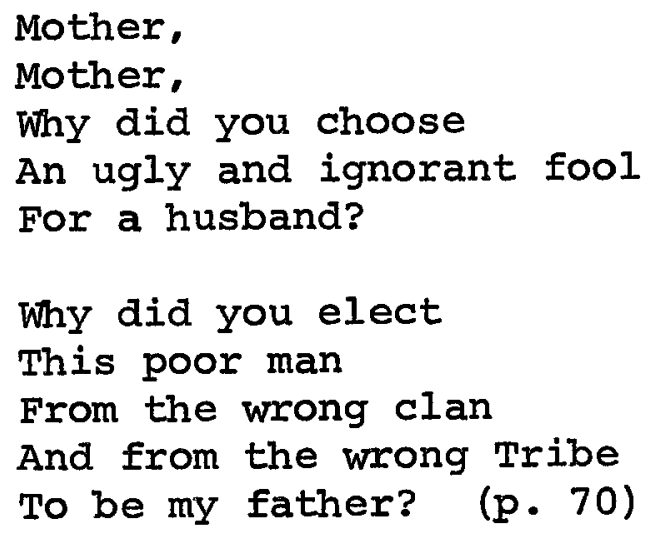

To use Edward Blishen's words, in these two sections of the poem, Okot is critical of:

- . the intolerable character of tribalism, and especially of tribalism wedded to modern politics, which may exclude so many of the beneficiaries of Uhuru from all prospects in life. 7

${ }^{7}$ Blishen, Introduction in Song of A Prisoner, p. 37. 
Indeed, one persistent problem within most African countries, excluding South Africa, is not the racial problem. Rather it is the problem of tribalism.

With the wide ranging indictment of political ills, what solution does Okot offer? The issue of what type of solution okot offers arises because of critics who say that the intellectual and the artist must be responsible to give a solution to the problems raised in a work of art. For example, Atieno-Odhiambo suggests that Okot's solution to the problems he raises in Song of a Prisoner is for the intellectual to dance and forget. Consequently, his objection: The prisoner must not go out to dance and forget. The intellectual must help the masses to rise out of the enveloping despair that comes with the expansion of the petty bourgeois class, into a feeling that they, the masses, can break the back of African capitalism any time. ${ }^{8}$

In fact in raising certain problems in their works of art, authors need not be obliged to offer solutions. It is sufficient for a responsible artist to pose problems and challenge his readers and his society to find solutions. In fact the ending of this poem does not propose solutions, it

8Atieno Odhiambo, "Okot and Two Songs: A Discussion," in Standpoints on African Literature: A Critical Anthology, ed. Chris Wanjala (Nairobi: East African Literature Bureau, 1973), p. 112 . 
only expresses the prisoner's unity of spirit with ordinary people in moments of joy.

I want to join the youths

At the get-stuck dance,

I want to suck the stiff breasts

of my wife's younger sister,

I want to wrestle

With my wife-in-law

And crush the young grass

Beyond the arena... (p. 108)

The prisoner also wants to join his "clansmen" (p. 108), his "clanswomen" (p. 108), his "age-mates" (p. 109) and all the other people in their customary celebrations and entertainments. Furthermore, the prisoner wants to dance all the dances of the world and sing all the songs of the world:

Cut off this rope, Open the steel gate,

I want to dance the dances

Of colonialists and communists,

I want to try the dances

of neo-colonialists

And African socialists,

I want to dance the dances

of our friends and

The dances of our enemies,

I want to lift their daughters

To my shoulder

And elope with them .. (pp. 112-113)

Relying on the above and similar quotations from the poem, some critics such as Atieno-Odhiambo have misinterpreted Okot's message by suggesting that dancing to forget or drinking to forget is the solution he offers. It is a serious misinterpretation to take such passages as the 
solution given by okot to the political ills cited in Song of A Prisoner. In fact, no solution is proposed. Firstly, the prisoner seeks freedom when he says:

Cut off this rope, Free my hands and feet, I want to clap my hands And sing for my children So that they may dance. (p. 107)

To use G. A. Heron's words:

Only after his freedom has been denied him does he seek to forget his very existence in the intoxicated hallucination of intercontinental dancing and copulation. 9

This is the spirit which the prisoner has been denied, owing to his political imprisonment.

Ultimately, one can say that despite the intensely personal, autobiographic tone of the prisoner, the song deals with mass ills, elite against poor, tribe against tribe, jailers against prisoners, and that in general it deals with the anger, frustration and rage expressed by any people anywhere in the world who are politically "in chains." The next song treats mainly the ills of society on a one-toone personal basis, the corrupt individual moralists.

In moving from political issues in song of $A$

${ }^{9}$ George Heron, "Okot and Two Songs: A Discussion," in Standpoints on African Literature: A Critical Anthology. ed. Chris Wanjala (Nairobi: East African Literature Bureau, 1973), p. 145. 
Prisoner to moral issues in Song of Malaya, Okot attacks the hypocrisy of those who use prostitutes and yet condemn them. He also attacks the would be guardians of contemporary African morality or the morality of the world at large. Ultimately, he even attacks the basis of their moral ideas. He uses the "Malaya" or "Prostitute" as his mouthpiece to portray the moral issues.

In Song of Malaya, Okot centers this discussion around promiscuity generally and prostitution specifically. In doing so, he portrays a prostitute as a productive, healthy person in a society. He indicates that people who deny the value of sex outside marriage or the value of prostitution are usually hypocritical and unwilling to admit the facts about human nature and human history. Song of Malaya is divided into seven sections, each of which treats a separate facet of the issue.

In section one, entitled "Karibu" (i.e., "Welcome!"), the prostitute welcomes the vast variety of men who enjoy her company. Many of those she welcomes come far from where she lives. Not only have they been frustrated for a long time, but some have been isolated from female companionship for years. She first welcomes the most frustrated, the sailor, the soldier and the prisoner detainee about to be released; 
others she welcomes include "'miners and engineers on rural projects,' 'teachers from bush schools,' 'bus drivers,' 'taxi men,' 'business executives' and 'shop assistants,' even political 'leaders of the people'"10 who after organising rallies are tired; their place of rest is with the prostitute. The common thing among these men is that all of them have been busy doing some kind of work and they are thirsty for sex and female companionship. The best description the prostitute gives of them is that they are "the hungry lions/Of the world" (p. 133) who compete with each other as they hunt for the Malaya. The Malaya who sings this "song" establishes a warm, tender welcome to all of them. She is so generous and sentimental that to the innocent novice she charges nothing.

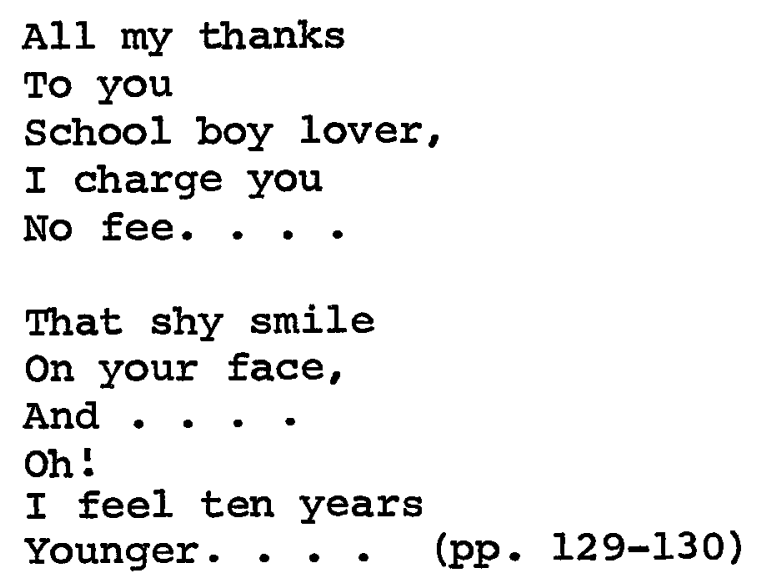

${ }^{10}$ okot p'Bitek, Two Songs: Song of A Prisoner and Song of Malaya (Nairobi: East African Publishing House, 1971), pp. 127-131. All subsequent references to the poem will be cited in the text by page number from this edition. 
But the prostitute is clearly portrayed as offering more than sex. She establishes an emphatic and generous personality, and incidentally establishes that her wares are essentially companionship. This is evidenced in her treatment of the tired politicians whose "voices are hoarse" as a result of making speeches. She is considerate to them.

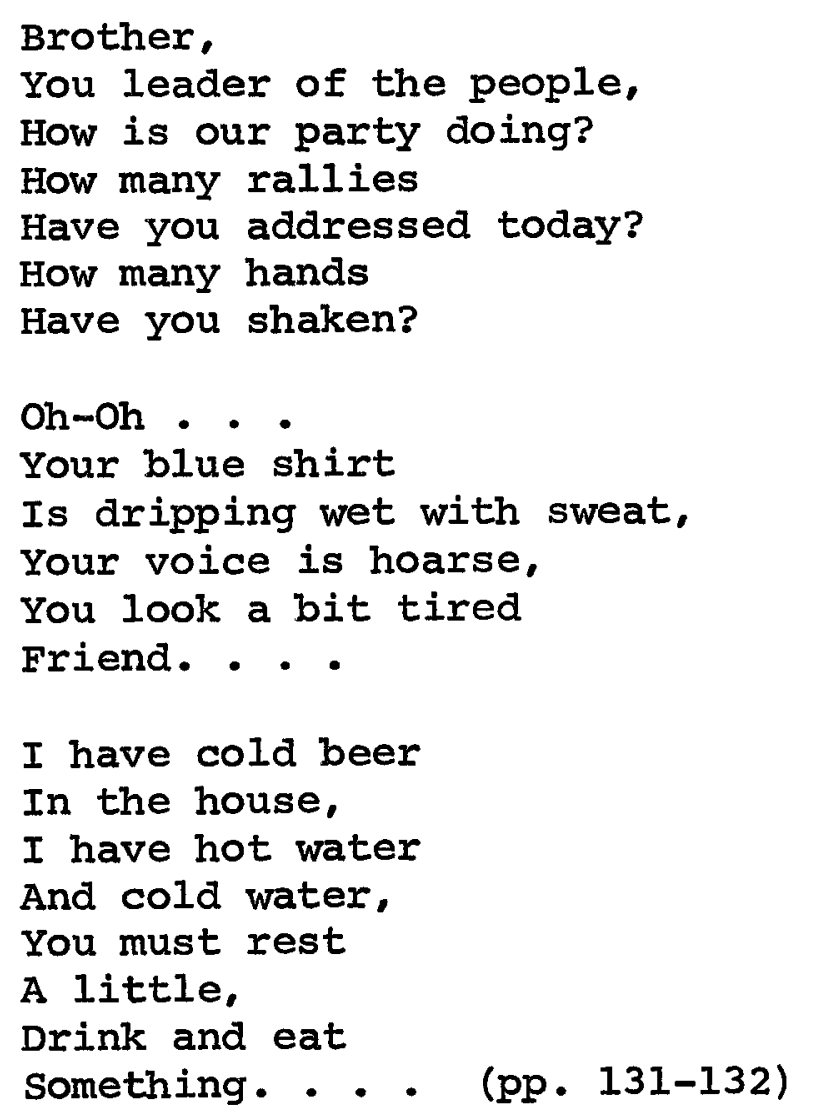

After the prostitute welcomes, she addresses the issue of extra marital sex generally. The title of section two, "Rich Harvest," refers to venereal diseases, which are one harvest of sex. The prostitute declares that such diseases should not necessarily be associated particularly 
with prostitution for they come from all types of promiscuity. The dramatic situation here is the prostitute's defense against a "Big Chief's" (p. 135) charge that the prostitute has infected him with a venereal disease. She denies guilt first by reminding him of another potential source.

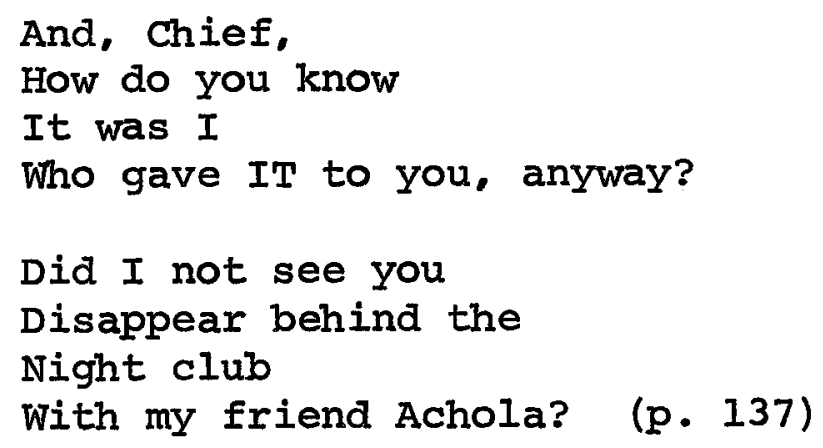

The prostitute goes on to say that no one can

seriously pretend or hope to eradicate promiscuity. The solution to the problem of disease is medical and should have a high priority as one of the goals of liberation. Consequently, the prostitute appeals to all those with influence, including "'mayors,' 'clerks,' 'headmistresses and headmasters,' 'Presidents,' 'Ministers' and in general 'Liberators of Africa'" (p. 140) to utilize all their resources and their revolutionary energy in eradication of venereal diseases in Africa--that is through medicine, rather than through vain attempts at an impossible and improper morality.

Where are the advisors

The experts and mercenaries? 
Can we not free Africa

From this one pest? (p. 140)

The prostitute's psychological aid and other serv-

ices to all types of men make her of significant value to society as a whole. This is mainly argued in section three, entitled "part-time" to refer to the prostitute's occasional service. For example, it shows how men with a variety of marital difficulties get comfort from the prostitute, and hence their marriages are actually fostered and saved by the prostitute.

And you

My married sister,

You whose husband

I also love dearly,

When will you learn

To be grateful

To me?

When you turn

Into a bloody bitch

And he storms out

of your house,

Mad at you, hungry, thirsty ...

Is it not I

Who give our man

Water to wash his face

And to bathe?

Is it not I

Who nurse and soothe him

Like my own baby?

Does he not return to you

clean shaven, smiling

Like a boy of fifteen 
Does he ever come home

With a dirty shirt . . .? (pp. 147-148)

Similarly, the sexually hungry students arriving in foreign lands are helped by prostitutes:

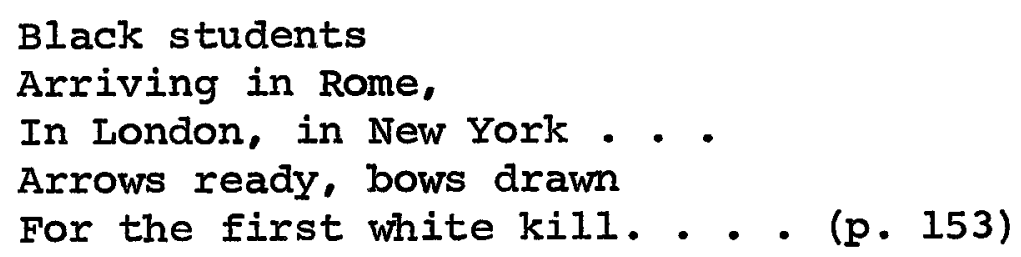

The prostitute's psychological service to the society as a whole is summarized in the passage below; the prostitute gives:

The open simple smile

For the egg-headed scholars

The hot devil smile

For the priests and their kind

The cool confident smile

For the faint-hearted and the unsure,

The innocent infant smile

For the fatherly and the senile,

The pious shy smile

For the thieves and the diseased,

The poverty-stricken smile

For the pot-bellied rich,

The haughty deceitful smile

For the politicians and robbers,

The girlish foolish smile

For the schoolboy

And the middle-aged nit-wit,

The frozen secret smile

For the dark-suited simpleton,

The quick winged smile

For the Chief's messengers and reporters,

The fearful savage smile,

For the poor white bastards,

The monkey town smile

For the opportunist get-rich-quick. . . (pp. 155-158) 
Section four, entitled "take the sickle," is in praise of promiscuity and critical of those who condemn prostitutes. For instance, in her argument here with a "black bishop" she finds it ironical for him to preach imported ideas of morality to Africans. Two ironies of the situation are that his father was polygamous, and he himself is illegitimate:

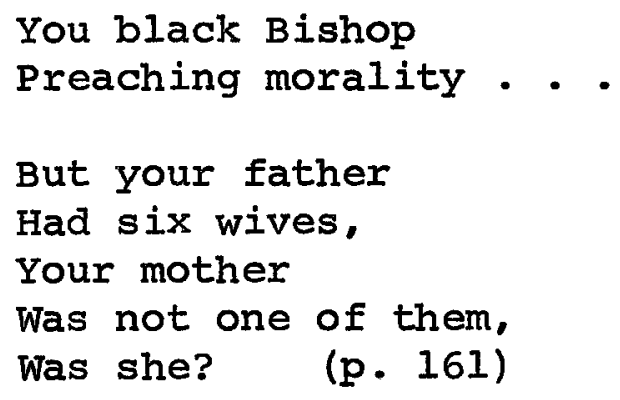

Okot questions such a "black Bishop's" values and the morality that he is advocating, which restrains girls from fulfilling their sexual needs:

What weak-kneed morality

You talk!. . .

Would you condemn

Other men's daughters

To a sexless life

Like nuns,

But against their will? (pp. 161-162)

To restrain girls from fulfilling their sexual needs is like "praying":

To God

To bless each bee

so that it should

stick to one flower? 


\section{3}

And each butterfly

And each moth

And each male ladybird,

Should it visit only one flower

In its life-time? (p. 162)

Or it is like restraining flowers from getting "visitors":

Would you take your sickle

And slash the flowers

In your garden

To ensure that the remainder

Have but one visitor

Each? (p. 162)

In this section, okot also questions the new moralists' ideas of monogamy. The prostitute, for example, questions the priest's philosophy of the wages of polygamy, that is, the fact that a man who is married to many wives and is responsible for taking care of them is liable to condemnation, while the Bishop, who is self-centered, egocentric, and does not accept any other responsibility beside taking care of himself, should go to heaven. Is this reasonable?, seems to be Okot's question.

And my grandfather

Will be burn

In the fire below

For loving ten women

And looking after their children,

While you go to the place above

Because you did not

Make love to a woman? (pp. 162-163)

Section four ends in praise of all the famous and powerful prostitutes who have contributed to sexual joy in the world. 
These include "the Egyptian girl who stole Abraham from Sarah's bed," "Magdalene who annointed the feet of Jesus," and "Theodora the Queen of Whores" (p. 166), to name but a few. One point of concern in this litany is that the history of sexual freedom in such forms as adultery, prostitution and promiscuity is as old as man himself.

Another point of concern is about Jesus' tolerance for prostitutes. For when Magdalene, a prostitute, anointed Jesus' feet, the moralists of the time accused Jesus of associating with a sinner. Behind the brief reference to Jesus and Magdalene, we may see Okot's belief that Jesus' view of prostitution and sex was not compatible with the Christian view. Okot has discussed this at length in African Religions in Western Scholarship.

It appears that it was the Pauline sex hatred rather than Christ's more humane attitude to women, that became the basis of Christian morality. When certain people raised complaints because a prostitute had anointed him with an expensive perfume, he told his host, 'I entered this thine house, thou gavest to me no water for my feet: but she hath washed my feet with tears, and wiped them with the hair of her head. Thou gavest me no kiss, but this woman, since the time I came in hath not ceased to kiss my feet' (Luke: Chapters $7,45-50$ ). When another woman was brought to him, caught 'in the very act' of committing adultery, and he was asked, 'Now Moses in the law commanded us that such should be stoned; but what sayest thee?,' Jesus stooped down and began to write in the sand as though he heard them not. When they persisted with their questioning he replied, 'He that 
is without sin among you, let him first cast a stone at her.' The accusers left. Jesus told the woman, 'Neither do I condemn thee: go and sin no more.' (John: Chapter 8, 3-11) 11

The point is that Africa's modern moralists must have got their attitudes from St. Paul's doctrines or somewhere else. But the attitudes do not come from Christ, for Christ showed tolerance for women who were prostitutes. However, this is not to suggest that either Christ or Okot considers prostitution to be a good thing. The African tradition considers polygamy healthy, but prostitution is not accepted in any typical African community. Therefore, as George Heron puts it, "The poem, Song of Malaya, is a song in praise of sexual pleasure. And sexual pleasure is a good thing in African tradition." 12

In section five, entitled "Pearls of Crying," Okot attacks the concept of illegitimacy and its effects on children. It hurts the child. Okot skillfully portrays this by creating a vignette or a dramatic picture of the prostitute waiting for her child to return from school. The child comes home crying because somebody called him a bastard. p. 116 .

${ }^{11}$ p'Bitek, African Religions in Western Scholarship, 12 Heron, "Okot and Two Songs," p. 41. 
The mother is stunned:

What?

Someone at school

Called you
A bastard
Illegit . . ? (p. 171)

Mother-Malaya consoles her child, mainly by arguing that even Jesus, the founder of Christianity, was a bastard. She intelligently asks :

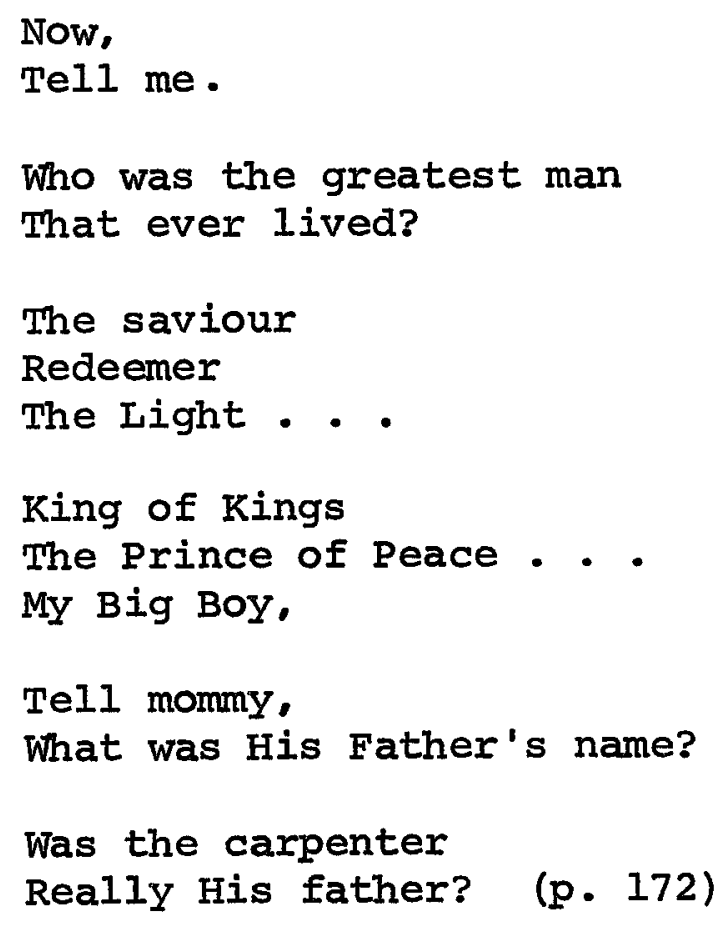

The irony of the situation is that Jesus Christ, the leader of Christianity, was conceived out of wedlock because the carpenter, Joseph, who married his mother thereafter, was by all accounts not his biological father.

In this section, Okot is also critical of the hypocrisy of modern moralists. For example, he suggests the kind 
of people who are fond of dubbing others as bastards are usually busy making bastards. A certain bush teacher is offered as a clear example.

The prostitute lashes at him:

And you bush teacher

Troubling my son,

How dare you

Throw the first stone

While Christ writes

In the sand?

How many teen-agers

Have you clubbed.

With your large headed hammer,

Sowing death in their

Innocent fields?

Who does not know

The little girls

In your class

Who are your wives,

And the children

That these children

Have

By you? (p. 173)

Okot extends his attack on hypocrisy in section six. Section six is entitled "the duet." "Duet" literally means "a composition for two performers."13 The section is so named because in it we are meant to understand that the prostitute is interrupted at various points by her brother, who objects to her shameful profession. The prostitute

13 Webster's New Collegiate Dictionary (Springfield, Mass.: G. C. Merriam Company, 1976), p. 352 . 
exposes her brother's hypocrisy. He is hypocritical because while he has a low opinion about her, owing to her profession, he himself is unfaithful to his wife. The prostitute exposes her brother's hypocrisy by revealing that he spent a night with her friend next door:

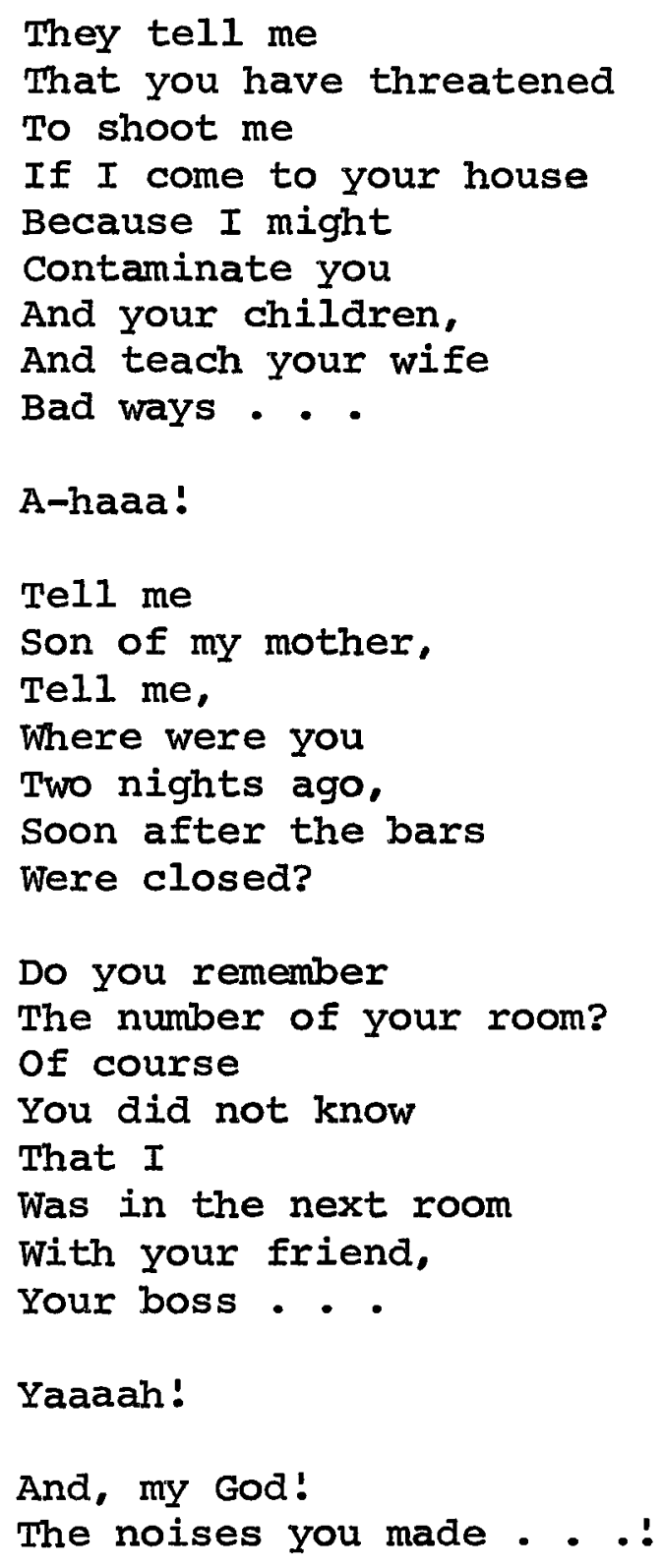


The soft drumming on the

Dancing mattress,

The bedstead gritting

Her teeth,

The duet. . . (pp. 176-177)

The issue of promiscuous sexual behavior is extended in section six. The prostitute further notes that her brother's wife may be unfaithful too. She vividly portrays the opportunities that his "beautiful Queen" has for adultery when she is at work or she goes to market or mass. (pp. 177-178) In the final analysis, the prostitute displays herself as a responsible, capable mother and good provider for her children. Consequently, she would rather her brother keep out of her business because she does not ask him for any help:

And you

Bastard son of my father,

I have not come to you

For help,

My children are healthy

And happy.

They do not go about

In tattered clothes,

Dirty, untrimmed ...

Why don't you

Just shut up . . ? (pp. 179-180)

In the final section, entitled "flaming eternity,"

the prostitute declares the permanent inevitability of prostitution, regardless of the strong legal measures and physical abuse applied by those who express contempt for it. 
Moralists with the excuse of doing their duty to prosecute the immorality of prostitution are hypocritical:

You sergeant

Arresting me now,

Sir,

But we were together

In my house

Only last night . . . :

And . . Oh-oh-oh . . .

- But how can you now

Call me

A vagrant? (pp. 181-182)

In fact, those who oppose prostitution are sometimes disappointed or diseased men.

Let the disappointed men

Shout abuses at us,

Let them groan, sleepless,

Their spears vomiting butter,

Their buttocks swollen

After the doctor's caning . . (p. 182)

Such men are suffering from venereal diseases. The word

"spears" is here used metaphorically to refer to their sexual

organs. "The doctor's caning" refers to "shots" or "injections" given to these sick men.

Others who oppose prostitution are women who are merely envious:

Let their jealous wives

Rage and beat them

With beer bottles

And stab them with knives... (p. 182)

Other women are opposed to prostitutes because they 
cannot endure the competition they meet in night clubs.

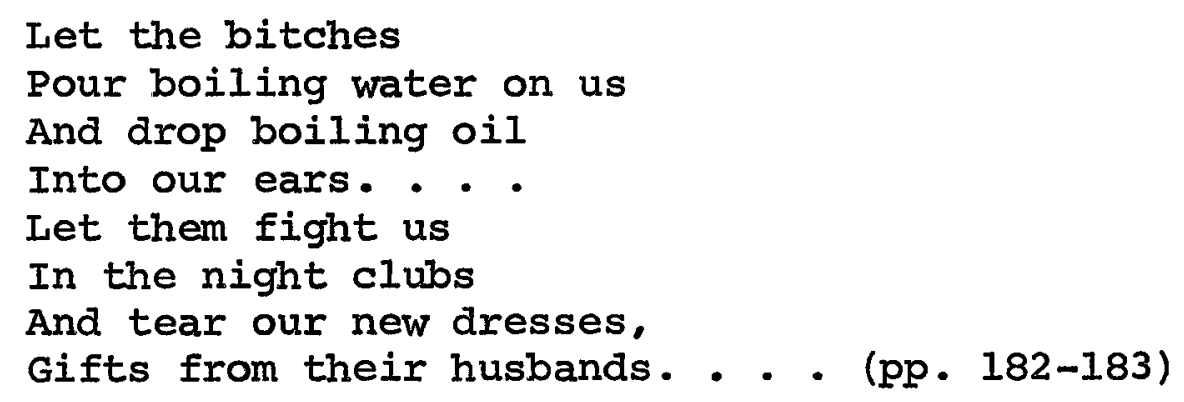

As for the clergy's opposition, it results from hypocrisy and frustration, as we saw earlier. Therefore the prostitute asserts:

Let the black Bishops

And priests

Preach against us,

Let them sow their seeds

In snow white fields

As they pray

To Saint Peter

Not to allow us

Through Heaven's Gate. . .

Let the Lord

Grant their prayers

And condemn us all

To flaming eternity. . . (pp. 183-184)

Whatever the efforts to frustrate prostitutes and eradicate prostitution, they cannot succeed because prostitution as well as sexual desire and its fulfillment are as inevitable as the succession of day and night. As the prostitute asserts finally:

But

Who can command

The sun

Not to rise in the morning? 
Or having risen

Can hold it

At noon

And stop it

From going down

In the west? (p. 184)

Therefore, to her fellow prostitutes, she says:

Sister prostitutes

Wherever you are

Wealth and health

To us all. . . (p. 184)

Song of Malaya thus reveals that extra marital sexual indulgence and prostitution do exist in society and are inevitable. It also reveals the hypocrisy of the so-called modern moralists in African society in particular, and in the world at large. Okot succeeds in portraying these themes by showing how indefensible is the society's moral vision that condemns the prostitute and prostitution. He then defends the prostitute without specifically defending prostitution. He defends the prostitute firstly by giving her an admirable personality. She is warm, tender, kind, generous and responsible. She takes good care of her children (p. 180), she is rational, intelligent and knowledgeable. She is aware of ways and movements of hypocritical people such as the "Big Chief," the "Bush teacher" and "her brother." They condemn her but they also engage in promiscuous sex. The prostitute is bold, unashamed and strong. 
She is also "Deadly lonely" (p. 171). This arouses our sympathy for her.

Secondly, Okot defends the prostitute with arguments. One of the arguments concerns the inevitability of widespread promiscuity and prostitution. Both are as old as the history of man. Therefore, some people, from man's origin to the present find promiscuity and prostitution beneficial. This is evidenced in section one, comprising a long list of the various types of men that use and enjoy the prostitute and in section four with its catalogue of prostitutes famous throughout history. Another argument is that of hypocrisy. Okot shows for example how the bush teacher is bold enough to call the prostitute's child a bastard, and yet he himself has bastards. (p. 173) Another argument is the irony of Christianity which condemns prostitutes and promiscuity when its founder, Jesus, was a "bastard" and tolerant of prostitutes.

Finally, Okot defends the prostitute by defending sexual pleasure and by showing that polygamy is more responsible than either hypocritical monogamy or even genuine celibacy. For example, the unnamed married man in the poem has three children with the prostitute. Why should he pretend to be monogamous when he is in fact "polygamous?" This 
is the same episode which also shows us that the prostitute is a healthy person in society. All these themes dealt with in Song of Malaya add up to a genuine challenge to the commonly accepted concepts of morality and sex in society. To borrow Bahadur Tejani's words:

Okot has given his historical and cultural sense full play in the Malaya's Song, which explodes all our notions of good and bad. The composition is one of the most daring challenges to society from the Malaya's own mouth; to see if we can stand to her rigorous scrutiny of ourselves. The prudes, the puritans, and the respectable have always frowned upon the streetwalker, the adulteress, the courtesan, the malaya. But the history of sexual deviation, of perversion, and temptation, is as old as man himself, embracing, according to the poet, the great names in world history. 14

Ultimately, one can say that in Two Songs: Song of A

Prisoner and Song of Malaya, Okot sought to expose the political ills as well as one overriding moral issue. Like the prisoner in Song of A Prisoner, most Africans in the post independent African continent are politically in chains. However, like the prisoner who wishes to drink and dance to forget his problems, they should be allowed some freedom to enjoy life despite the political problems. Song of A Prisoner also exposes tribalism, a major problem

${ }^{14}$ Bahadur Tejani, "Okot p'Bitek," in African Literature To-day, ed. Eldred Dunosimi Jones (New York: Africana Publishing Co.. 1973), p. 163. 
in present African societies. On a more universal level, Song of A Prisoner articulates the anger, despair, frustration and fury expressed by anyone anywhere who is in political bondage. As for modern moralists portrayed in song of Malaya, Okot is particularly critical of their hypocrisy. He is saying that they should practice what they say or else shut up. They should also reexamine the moral ideas from which they work. Society in general should not condemn prostitution and promiscuity, if in fact it encourages their existence. Both songs are passionate defenses of the condemned and abused, the oppressed people of the new independent African society, who nonetheless are optimistic about their future, irrespective of their current hardship, hunger, and humiliation.

In the previous chapter, we were mainly concerned with the ideas transmitted in Okot's poetry. However, for a better comprehension of these ideas it is essential that one has a clear understanding of how okot conveyed his ideas. Therefore, the next chapter deals with techniques of okot p'Bitek. 
Okot uses a variety of techniques which enhance effective communication of his ideas in the "Songs." Each of the four "Songs" is a dramatic monologue. The intention of each song is to make didactic points. Consequently, the dramatic structure of the poems is used to support a wide range of didactic themes. It enables the speaker to address various different individuals and/or social groups, commenting on the social, economic and political ills of African countries in particular, but also of the world at large. In this chapter I will discuss the basic thematic organization and dramatic framework of okot's songs, and the selective techniques which he employs to maintain the unity of each song and yet invest each with passion, realism, rhetorical cogency and poetic beauty.

A definite thematic sequence is employed in all the songs. For example, in Song of Lawino, Lawino introduces the readers to the situation of the poem, then she comments 
on one particular aspect of Western influence on Acoli tradition in each of the sections that follow. In his answering song, Ocol, like Lawino, section by section comments on one theme after another. First he generally condemns the "Blackness" of Africa, and his own "Blackness." Next he mocks the abuse of African women, and then the poverty of East African pastoral communities. In the following section, Ocol acting as a political leader shows why he is rich at the expense of those who fought for freedom. By presenting Ocol's range of thinking and excuses, Okot aims to demonstrate how and how much the hopes of political freedom have been betrayed by the brainwashed African elite.

In Song of Malaya, the thematic structure is used to criticize Africa's modern moralists' condemnation of prostitution. The criteria for their moral philosophy and their hyprocrisy are criticized. Each section treats a different aspect of the themes: promiscuity and prostitution.

In Song of a Prisoner, similarly, thematic sequence is applied. The thematic approach passes from one to another aspect of Okot's social, political, and economic concerns, from scene to scene to scene. These aspects are linked by the fact that in section after section, the prisoner pleads for justice. The poem ends by expressing something which 
transcends political issues. The poet and the prisoner sing a hymn to the joy which is known to all peoples and denied to prisoners.

Thus we find that each song is divided into sections or chapters which discuss separate themes related to the overall subject and didactic intent of the poem. But each of the "songs" is a string of themes which is closely woven together by the dramatic structure, especially the personality of the person delivering the monologue.

It is primarily through characterization that the author establishes a vivid dramatic medium for his didactic message. As said earlier, each poem is a dramatic monologue. It is the striking personality of each of the speakers of these monologues which gives life, urgency and passion to Okot's theoretical discussions of East African society. This can be demonstrated by examining the character's personality in each poem, as well as some of the minor personalities.

In Song of Lawino, the protagonist is tolerant and outspoken, as well as an intellectual who can forcefully argue the issue of Western values competing with Acoli (or African) values. She is proud of herself as a person, as well as for her achievements. She is proud of the popular 
family she came from. She is proud of and knowledgeable about customs. She can dance, cook, take care of her family and do almost everything that is expected of any decent Acoli woman. She is indeed the paragon of her village. According to Acoli standards she is beautiful and eloguent. Through the intelligent character of Lawino, Okot succeeds in making the point that the society Lawino represents, Acoli (or African), is strong and stable. On the other hand, she exposes the hypocrisy and immorality of Western societies. The hypocrisy and immorality of Western societies is exposed not only through the protagonist but also through the minor characters as well. For example, through the character of the missionary teacher. He is hypocritical, for he goes to meetings when he is drunk, and contrary to his teachings, he hunts for girls. ${ }^{I}$ Therefore through the hypocritical, immoral character of the "Christian protestant teacher," Okot is able to portray the fact that the Christian religion is not as moral and superior as it professes to be.

In the same poem, Okot through another minor character, Clementine, presents the falsity and artificiality of Western

${ }^{1}$ okot p'Bitek, Song of Lawino and Song of Ocol, A Combined School Edition (Nairobi: East African Publishing House, 1972), p. 122. All subsequent references to these poems will be cited in the text by Lawino or Ocol and page number from this edition. 
beauty. Clementine, Ocol's mistress, is presented as a black Westernized woman who is sophisticated but "pitiable" (Lawino 42), she is sickly and "her breasts are completely shrivelled." (Lawino 44) "She looks as if she has been ill for a long time!/Actually, she is starving." (Lawino 45) She also adopts artificial aids to beauty such as wearing wigs and bleaching her skin. We are never allowed to admire her. Consequently, through the character of clementine, Okot shows that in African eyes what the Western society considers beautiful is not beautiful, and shows therefore that there is a cultural difference between different societies. In Song of Ocol, Ocol is the main character. He is rude, abusive, arrogant, intolerant and irrational. He is excessive and has hatred for himself. We are not allowed to respect him. Ocol's character makes it easier for Okot to make his point about the African elite who were brainwashed in the missionary schools. His point is that while they blindly insist on following the ways of westerners, they are foolish because they misunderstand their own ways, and hence they do not know themselves.

The most fascinating characterization is that of the prisoner in Song of A Prisoner. The prisoner seems to comprise two prisoners. One is a former murderer, dismissed 
bodyguard and a vagrant. Another is a disgraced minister. Whether vagrant or minister, the characteristics of each are similar. Each maintains pride in his deed of assassinating the corrupt politician. Each attacks the circumstances and neither of them calls for pity. The prisoner's human dignity is maintained in his dehumanising situation. Both are strong, heroic, courageous, and responsible to their families. Hence each has nobility of character. It is through such characterization of the prisoner and through the single situation of this composite prisoner that okot comments on the despair and fiercely expressed anger of anyone anywhere who is politically in chains. Secondly, he makes the prisoner heroic to show that the hopes of freedom in post independent African countries have been horribly betrayed. His cry is for political justice.

In Song of Malaya, Okot's mouthpiece is a persuasive, sophisticated, intelligent and knowledgeable character. She is very knowledgeable of men's ways and movements. She sees through people. Through her okot explores the thinking which leads the so-called moralists to demand guilt and shame from other people for their sexual behavior. For example, the Malaya is sharp enough to have facts and situations at her fingertips. She knows how to silence her brother's sham 
morality by pointing out that he in fact shared a bed with her friend next door two nights ago. She is very realistic and unashamed of her deeds. She knows that she provides a service to society. She is portrayed to be moral (good). For example, she is tender, loving and intimate, and has humanitarian feelings for people, feelings which extend beyond any of the requirements of prostitution itself. Indeed her kindness sometimes surpasses the wedded-wife's. The Malaya tells the wife:

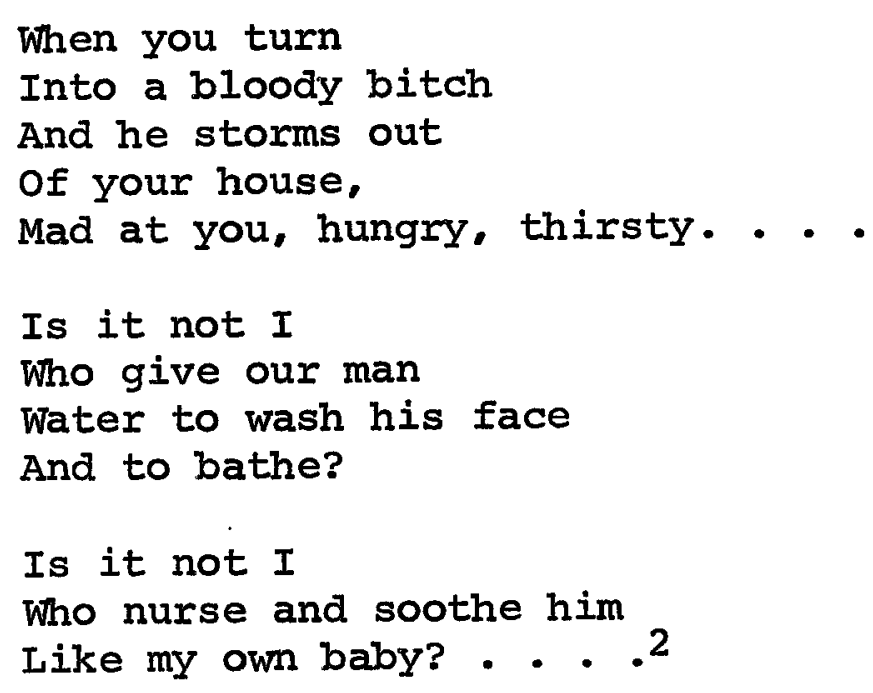

By making the prostitute such a wonderful character, intelligent, humorous, moral and generally admirable, okot is able to successfully criticize the hypocrisy of Africa's

${ }^{2}$ Idem, Two Songs: Song of Malaya and Song of A Prisoner (Nairobi: East African Publishing House, 1971), p. 148. All subsequent references to Song of Malaya poems will be cited in the text by Malaya and page number from this edition. 
modern moralists as well as the hypocrisy of those who make use of prostitutes but nevertheless condemn them. He also succeeds in attacking the moral ideas or basis from which such "so-called moralists" operate.

In Song of Malaya, characterization of minor characters is also quite detailed. For example, we learn that the Black Bishop preaches a type of morality which restrains "other men's daughters to a sexless life." (Malaya 162) He preaches against polygamy and yet his father had six wives; he himself is illegitimate. Therefore okot is challenging people like the Black Bishop to reexamine the kind of morality they preach. Similarly, the characterization of the unnamed man who has a wife with two daughters and who also has three sons with a prostitute is quite revealing. Okot is saying that the Christian monogamy is hypocritical, and that traditional polygamy is healthy and honest. Thus characterization of both the major and minor characters in Song of Malaya serves as a good weapon through which the author presents moral issues.

But drama needs plot as well as character. In each of the four "songs" a form of plot contributes to the dramatic power of the poem. The nature of the plot structure varies, however, from song to song. Lawino has a full 
plot with a complicated past history of relationships among the three main characters which have led to the present moment of crisis. Ocol relies on the plot and character established in Lawino, but does not advance the story very much. In Prisoner okot daringly combines two past histories into one unified and sustained dramatic situation. In Malaya, Okot allows one fully developed protagonist to face a series of unrelated crises or confrontations. The different forms of plot can be demonstrated by examining each song independentIy .

Song of Lawino has the most fully developed plot because the reader is exposed to the former and present relationships of Lawino with her husband, Ocol. The relationships between Lawino, Ocol, and his mistress, clementine, are also revealed. Ocol has rejected Lawino, the unwesternized village woman, in preference for clementine, the woman supposedly beautiful by Western standards. The problem stated is how Western education has brainwashed and consequently alienated the African elite from their culture.

In Song of Ocol, the author, Okot, is working with a plot already in progress as begun in Song of Lawino. The Song of Ocol does very little to supply facts about Ocol's history. Instead, Okot immediately continues the plot by 
having Ocol divorce Lawino in response to her monologue. Then ocol in each section seems to address a new and different category of accusers, such as traditional women, traditional pastoral men, and the dispossessed urban workers.

In Song of A Prisoner, there are two histories and, therefore, two biographies of two different prisoners. However, they are blended in together because of the concentration on the single prison situation. This single dramatic moment and setting, that is, this single moment in a plot conveys the full despair, anger, fury, and fiercely expressed frustration of anyone anywhere who is in political imprisonment.

In Song of Malaya, there is no single plot; instead, there are different little stories, one of which comes out in each section of the poem. For example, in section two the "Big Chief" and his sexual relationship with both the prostitute and Achola are exposed. His consequent venereal illness is also revealed. The question posed is that of health. What is the cure for these diseases brought about by indispensable promiscuity and/or prostitution? And in section five, which is another little story, the Malaya's child comes home crying because somebody had called him a bastard. The issue of this section is hypocrisy, because 
the "bush teacher" who calls Malaya's son bastard has many bastards himself. Another story concerns the Malaya's brother, who has contempt for her because of her prostitution, and yet he himself engages in promiscuous sexual behaviour. Here, again, the question of hypocrisy is posed. Despite their disparities, all the stories in Song of Malaya are similar because they are linked by the personality of the Malaya, by the hypocrisy of the antagonists, and by the close relationship between the moral issues of the separate sections.

Vignettes are also employed by okot in the "songs." By vignette we mean a type of short story with a slight sketch distinguished by its delicacy of portraiture. For example, Lawino's description of the evening when she ran away from the Catholic evening speaker's class to join the dancers in the "get-stuck" dance is a vignette. This vignette is extended by another one of the teacher's joining in with the dancers and trying to whisper to Lawino:

Shamelessly The ugly man Whispered something in my ear! And touched my breast With the rough palm of his bony hand Cutting it as if with An old rusty knife. (Lawino 122)

Such a vignette is didactic; it is used to expose the 
hypocrisy of Christian missionaries. Similar vignettes occur in Song of Malaya. For example, the poet creates a warm human picture which we have mentioned: Mother Malaya waiting for her child to return from school. Okot uses this vignette to comment on the basis inconsistent and ironic basis of these Christians' morality. Their ideas are inconsistent because they also worship Jesus Christ, whose father is unknown, and whose mother conceived out of wedlock and before she "knew" Joseph, the carpenter. Thus Jesus Himself is a bastard. Such reasoning makes the vignette both didactic and humorous, while the child's grief makes the vignette serious and poignant as well. Such a vignette is both didactic and humorous. Through vignettes such as this one, Okot appropriately creates vivid scenes which are sometimes pathetic. Whichever the case, these vignettes are not just deeply emotional in varied ways of humor, charm and pathos but, by and large, didactic as well as dramatic.

In order to reinforce the passion and conviction with which each speaker addresses her or his dramatic crisis, and in order to reinforce the social ideas that okot is arguing, the poetry employs a number of rhetorical devices in striking ways. Particular attention should be given to Okot's use of apostrophe, anaphora, various other forms of repetition, and 
alliteration.

Okot makes much use of apostrophe, that is, the figure of speech in which a person or personified idea is directly addressed. Lawino usually and very frequently addresses Ocol as "my husband," and she does so in various passages which convey by their varied tones her pleas, anger, pride and love. In other passages she addresses her clansmen and family: "My clansmen, I cry" (Lawino 37), ... "Brother, when you see clementine." These instances of apostrophe serve to establish a vivid setting in which the married couple and their families are assembled to settle a marital dispute, and one (loving) antagonist is making her case.

In Song of Ocol, like Lawino, Ocol uses forms of direct address. But unlike Lawino, his are more harsh. First he addresses his wife in the course of chasing her away •

Woman

Shut up:

Pack your things

Go: (ocol 199)

After this apparently real case of addressing someone present, Ocol's apostrophes seem more artificial. In his rejection of his Africanness, for example, he addresses his mother (who may or need not be imagined to hear him): 
Mother, mother

Why

Why was I born

Black? (Ocol 208)

In his condemnation of abuse of African women, he addresses "Woman of Africa" (Ocol 222), "Woman from Kikuyuland" (Ocol 220) and a woman or sister from a variety of the East African tribes. Similarly in his condemnation of the poverty of East African pastoral communities, he addresses one particular tribe after another, despising their major occupation and/or their location and way of living. For example: "you mountain dwelling sebei" ( 224).

Ocol also addresses persons who could be present, as "my friend and comrade" ( (Ocol 239) or "you cowardly fool" ( addresses people by their nationality: "you Pigmy men" ( 243), "you Indian dukawallah" (Ocol 224) and "you loyal Muganda" ( $\underline{0 c o l} 244)$. Sometimes he addresses people by their occupation: "Your Excellency/Bwana President" (ocol 250), or You Honourable Ministers" (Ocol 251), "Black Bishop" (Ocol 251), "You Worshipful Mayors" (Ocol 251), "You Scholar" (ocol 252) and so forth. The many people addressed in song of Ocol indicate that okot wanted to comment on many areas of life. But in each section, Ocol addresses with apostrophe the 
person or groups whom he is attacking. Thus the apostrophe serves several purposes. It announces the subject of the section. It intensifies our impression of Ocol's passion and harshness to imagine him throwing such insults directly at people. It also helps to define scenes of dramatic confrontation. Thus in song of Ocol, apostrophe is used to vary tone and the desired effect okot wants. It also shows the type of attitude either respectable positive, or negative attitude Ocol has towards whoever he is addressing.

In Song of A Prisoner, as we have seen, the dramatic wholeness is threatened by the amalgamation of the two prisoners into one. The single wholeness, however, is reinforced by the single dramatic situation of the prisoner, his single personality and the single, uniform situation of being surprised and distressed to find himself imprisoned. Okot uses apostrophe to underscore this dramatic unity; the prisoner usually addresses his guards and tormenting inquisitors (unless he is recalling the court-rooms and therefore addressing the judge). The reader can imagine that the persons addressed are physically present in exceptional cases, as when ironically the prisoner accuses his parents of marrying unwisely, the scene and rhetoric seem no less realistic. In Song of Malaya, sometimes the protagonist addresses 
her fellow prostitutes:

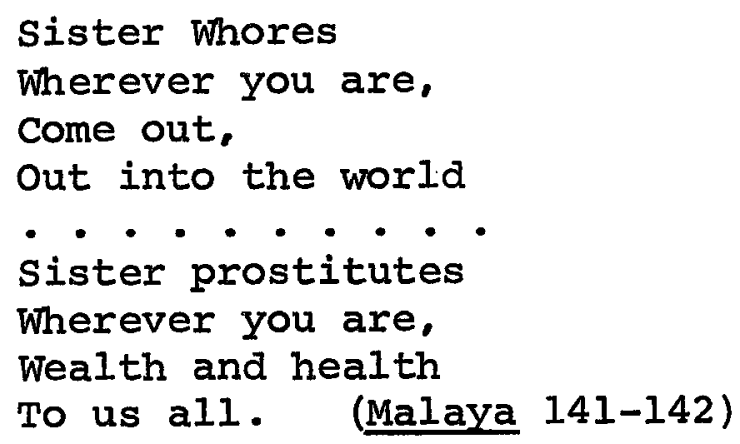

At times she addresses the woman with whose husband she has an affair as "sister" (Malaya 149), or "my friend" (Malaya 150). This type of address is both ironical and sarcastic. In criticizing the African modern moralists, Malaya addresses the priest "you Black Bishop" (Malaya 161), she also addresses her child "my sweet baby" (Malaya 169), and finally she addresses the immoral instructor as "you bush teacher" (Malaya 173). Here again apostrophe is used to vary tone according to the desired effect.

The Malaya is knowledgeable; she has facts about men's ways in general and the specific movements of her fellow citizens. She uses such knowledge to defend herself when criticized. For example, she uses that kind of information to silence her brother's hypocritical morality by revealing that he in fact shared a bed with a woman. She addresses him: 
And you brother

Son of my mother

Where were you

Two nights ago

Soon after the bars

Were closed? (Malaya 176)

She also addresses "Angel Prostitutes" (Malaya 154), "you

bush teacher" (Malaya 173), "you soldier" (Malaya 128), "you drunken sikhs" (Malaya 128), "you Indian vegetarian" (Malaya 129). "you factory workers" (Malaya 131) and many other people who interact with the prostitute. We have seen that Song of Malaya is a group of separate scenes unified by the central speaker as she confronts varying situations created by different hypocrites, or as she invites and supports men who need her trade. Thus her apostrophes help to establish each scene, define her opponent, display her attitude, and reinforce her emotion.

The effect of apostrophe as used in all the "songs" is that it enables the protagonist to outline his/her ideas much more economically than a narrative explanation would permit. Also apostrophe is used in the "songs" to have certain impact on whoever is being addressed. For example, when Lawino addresses her husband Ocol, she wants to reason with him so that he may change his attitude towards her. But when she is addressing her clansmen, she is appealing 
for sympathy. The prisoner's use of apostrophe reveals his life with details about his mother, wife, children, poverty and his background in general. Through apostrophe, his plea for justice is intensified. In all the "songs," apostrophe introduces dramatic confrontations which cause the protagonists' outbursts. It produces a framework for each poem's 'discussions.'

Anaphora and repetition are other kinds of rhetorical devices employed in the "songs." By anaphora here, we mean specifically the device of beginning successive lines of poetry with the same word or phrase. By repetition we mean specifically repeating of same stanzas and sometimes repeating of the same idea in different phraseology.

Okot uses anaphora and repetition so skillfully that the repetition achieves the effect of seeming to pile up evidence. Anaphora while it achieves this sense of piling up evidence also conveys the speaker's passion. Furthermore, anaphora also achieves an attractive musical effect and emphasis. For example, in lamenting her rejection by Ocol and Ocol's insults to her, Lawino explains:

My clansmen, I cry Listen to my voice. The insults of my man Are painful beyond bearing. 
My husband abuses me together with my parents; He says terrible things about my mother And I am so ashamed!

He abuses me in English

And he is so arrogant.

He says I am rubbish

He no longer wants me:

In cruel jokes, he laughs at me,

He says I am primitive

Because I cannot play the guitar,

He says my eyes are dear

And I cannot read

He says my ears are blocked

And cannot hear a single foreign word

That I cannot count the coins. (Lawino 37-38)

Here, we can see the device of beginning successive lines of verse with the same phrase, 'He says' in the last lines of the above quotation, and with the same word 'And,' in the last four lines of the quotation. Here Okot skillfully uses such a repetition not only to achieve an attractive musical effect, but also to serve as well the purpose of emphasis. The point being emphasised is the griping of Ocol, pouring insults at Lawino in the course of his rejection of her simply because she does not embrace Western values.

Repetition is used on various levels in the "songs" for emphasis. In Song of A Prisoner, repetition is used on two levels. On the one level, it is used to emphasise the single dramatic unity of the situation. On the other level, repetition is used to emphasise where the guilt lies. In 
both cases repetition is on the level of repetition of a specific stanza or of certain sounds. A certain stanza recurringly appears in the poem Song of A Prisoner to emphasise that the protagonist as a prisoner is being questioned. It also serves as the introduction to the exposition of social and political injustice; it leads us to problems of disease, poverty and unemployment as seen by the prisoner. The stanza is :

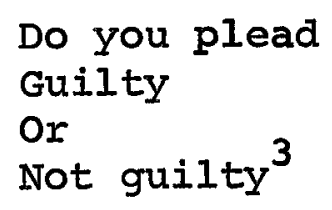

The significance of this repetition is that it serves as a key to a revelation of various themes. Each time this stanza occurs it is followed by a passage which asserts or implies that the prisoner's guilt is irrelevant, and the society's guilt is overwhelming.

In response to the above question, the prisoner pleads anger, hatred, drunkenness and despair because of his pathetic condition caused by the political injustice in the country

3 Idem, Song of A Prisoner, with an introduction by Edward Blishen (New York: The Third Press, Joseph Okpaku Publishing Co., 1971), p. 54. All subsequent references to this poem will be cited in the text by Prisoner and page number from this edition. 


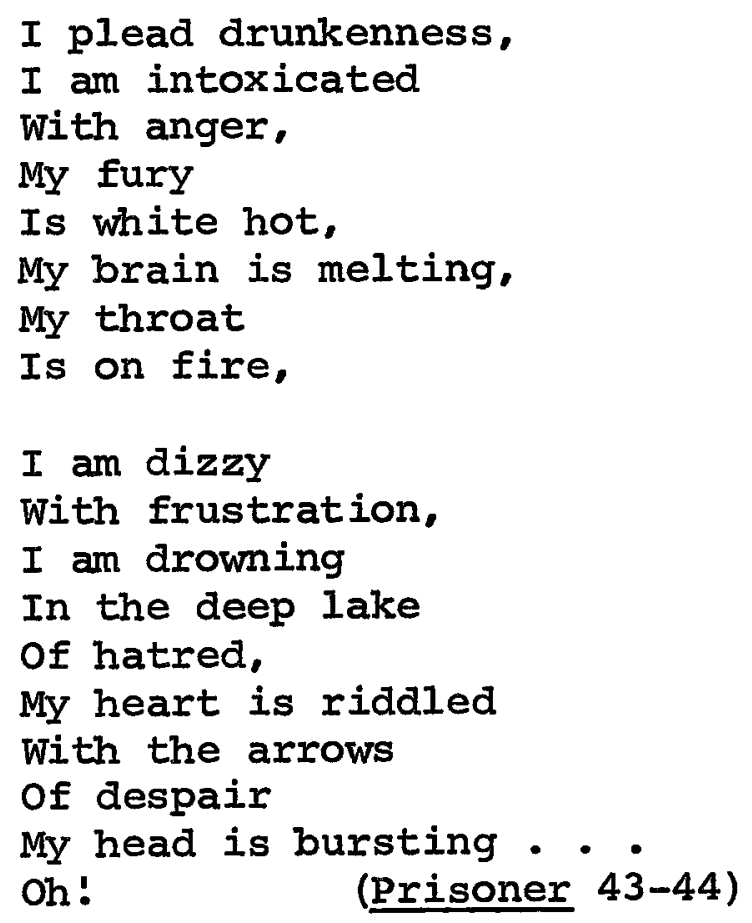

The use of words like drunkenness, melting, dizzy, drowning and so forth, serve to express the situation which the prisoner is in, namely, pathetic, pitiable and tortured. At another instance when the same question is asked, the prisoner pleads smallness, fear, helplessness, and insanity owing to his problems both at home and in prison. At home, his wife possibly has an affair with a richman and his children are excluded from school and employment. In prison he is tortured mentally and sometimes physically.

I plead smallness

I am a mere

Pygmy

Before your Uniformed power Which towers like Mount Elgon 
And covers the land

With its dark shadow,

I plead fear,

I plead helplessness

I plead hopelessness

The cry of my children

And the sobs

of my wife

Haunt me like

A vengeful ghost (Prisoner 56-57)

When the same question is asked again, the prisoner pleads pride. He has pride in the fact that his clansmen, his father, wife and children respect him.

I plead guilty

To pride

I was not born to this,

I am a great soul

My mother knows this

My uncle told me so,

And my father was proud

of me... (Prisoner 105)

He demands his release, firstly to express his pride in his role within his own clan, and then to forget his despair of his role within the new city. Immediately following the above words of the prisoner, there is a detailed revelation of the life of the prisoner's family. He tells of his poverty as a result of which his children suffer from hunger. We also learn that his children are sick of Kwashiokor, due to the lack of food. Owing to the prisoner's poverty, his children are uneducated and hence they do not hope to get 
employment:

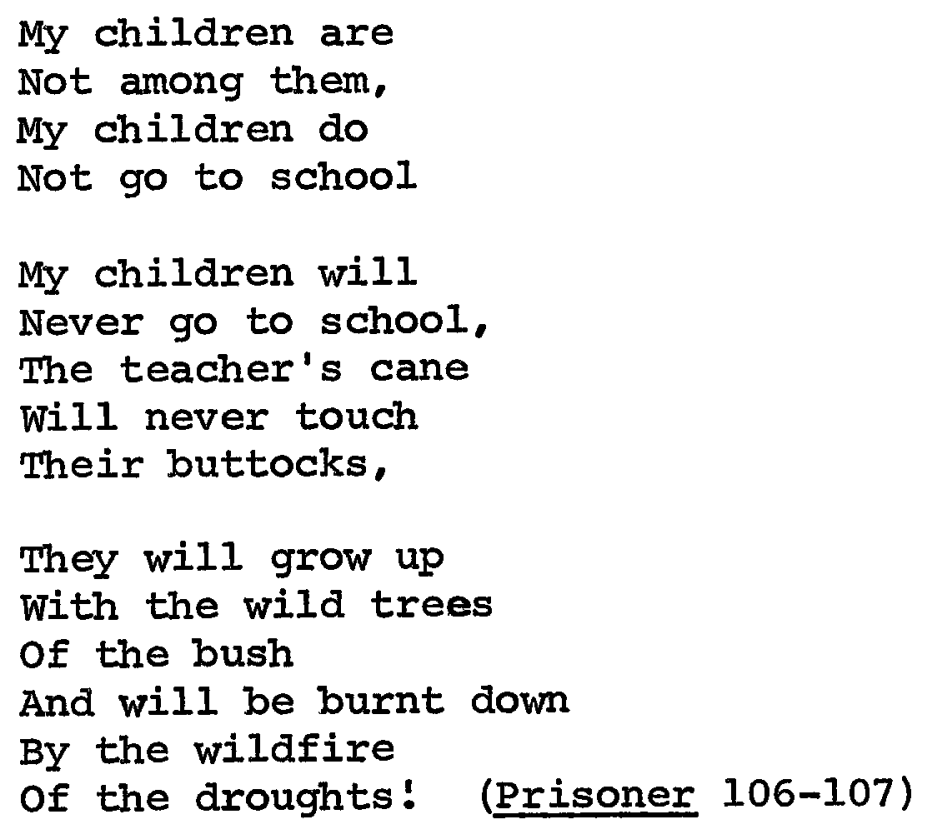

The prisoner also responds to the repeated question by telling us about his wife. We learn that his wife has been possibly raped by a richman who owns a Mercedes.

Therefore, one can see that the repetition of the above stanza is very significant to the poem. Firstly, it leads to a revelation of various themes as listed above. secondly, the stanza itself becomes a theme and a refrain, ironically calling for justice, and calling forth the prisoner's passionate responses. Finally, through the repetition of that same stanza in various sections of the poem, we learn that the poem is not just about a single prisoner in jail, but rather about people who are politically deprived, and as a consequence, poor, miserable and full of 
despair and anger. The refrain, therefore, contributes to both the thematic and the dramatic unity of the poem.

In addition, there is also a repetition of sounds in Song of A Prisoner. For example, in the stanza below:

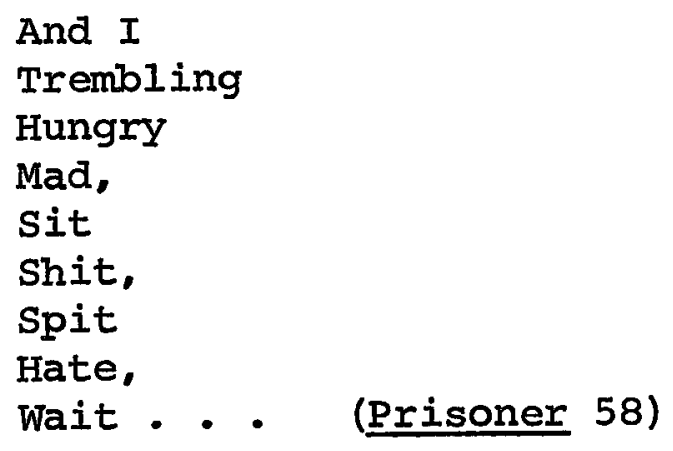

The ' $S$ ' sound's repetition combined with the hate/wait rhyme emphasises the prisoner's fiercely expressed anger. In Song of Malaya, also, there is a complex use of a refrain:

Sister prostitutes Wherever you are Wealth and health To us all .. (Malaya 181)

This refrain is used time and again by the prostitute. The messages it underscores are that promiscuity and prostitution are inevitable, and that it is through prostitution that the 'wealth' and, ironically, 'health' of the prostitutes are achieved. The point to note is that the stanza comes at the end of each little story which demonstrates hypocrisy of those who condemn prostitution. For example, it comes immediately after the prostitute's exposition of the 
hypocrisy of the bush teacher who dubbs her child a bastard though he himself has bastards. And it comes after a story which demonstrates that prostitution and promiscuity are as old as the history of man. That same stanza also closes the poem and immediately follows a catalogue of reasons why people oppose prostitution and promiscuity. Therefore the stanza is employed to justify prostitution and promiscuity as well as to show their inevitability.

Repetition is also used as a key to the meaning of the poem. For example, in Song of Malaya, the term "Karibu" (Malaya 129), a Swahili word which literary means "welcome," is repeatedly used to show how warm the prostitute is when welcoming people of all walks of life and hence her inevitability, in society.

Alliteration and rhyme are used in the "songs" to arrest attention as well as to forcefully portray the meaning of the poems. Alliteration and rhyme, like repetition, make vivid the image portrayed. They are also used to produce greater humour. Finally, they are used to make poetry more "poetic" and charming.

Alliteration and rhyme in Song of Lawino are very mild. In fact they are surbordinated to anaphora in order to forcefully portray the meaning of the poem. For example, in 
the following stanza:

Women lie on the chests of men

They prick the chests of their men

With their breasts

They prick the chests of their men

with the cotton nests

On their chests. (Iawino 52)

Through the rhyme in "breasts," "chests" and "nests," the evaluation of Western dance is made. The explanation, joke and accusation of immorality of white people's dances is captured. The stanza below appropriately demonstrates how alliteration is buried in anaphora not only to arrest attention but to forcefully expose the immorality of Western dances :

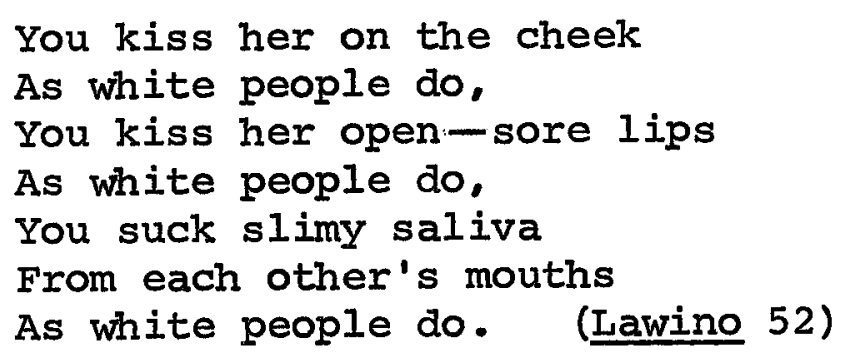

There is very mild alliteration occuring in "you suck slimy saliva," subordinate to the immense anaphora in the whole stanza.

However, alliteration in song of Malaya is more pronounced. For example, in the following stanza when the prostitute criticizes the jealous wife:

Your eyes are black

with jelousy 
The veins of your neck

Are bursting with boiling blood

Biting her lips, Who's that brute

Her fists clenched,

Tears streaming down her cheeks.

(Malaya 148-149)

Here, one finds that there is a recurrence of the same initial sound in words that are consecutive or sufficiently close to produce a noticeable effect as in "boiling blood" and so forth.

The poet captures the art and practice of public speech in the use of words such as "you" or "we" in reference to another character being spoken to in the poem but not the readers. This is used in all the songs. For example, in Song of Ocol, Ocol uses the term "we" to refer to himself and his counterparts (Western elite), who are in agreement with his point of view, and are willing to act as a collective group to destroy all the black images of Africa.

We will not simply

Put the Masai in trousers (Ocol 228)

but

We will rip off

The smelly goatskin skirts

From the women

(ocol 229)

and so forth. Here, one would think that the reader is implied in "we" but he is not.

In all the "songs," rhetorical devices are used 
effectively to portray the didactic themes of the "songs." They include alliteration, apostrophe, anaphora and repetition. In all cases, they are used to achieve grace, forcefulness and persuasiveness of the messages relayed in each 'song.'

Humour and satire are other techniques used to great advantage in the "songs." Satire is employed to ridicule human weakness in an instructive manner as well as in a humorous way. It excites amusement and sometimes awakens the reader's scorn for untruth. Lawino's description of Ocol as a "dog" to the whiteman blindly emulating Western values, is satirical. In this case, Lawino satirizes Ocol's ugly behaviors in many instances. For example, she satirizes his behavior towards the children. Owing to Ocol's adaptation of the Western value of 'time' he is emotionally distanced from the children.

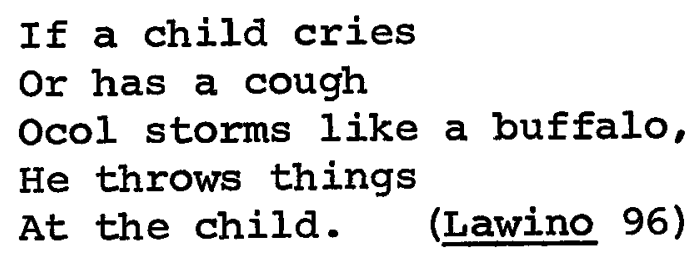

Lawino also satirizes the Christian missionaries by accounts of their hypocritical statements and immoral behaviour. So satirical is the character of Lawino throughout the poem that David Rubadiri, in his opinion and other critics' opinions 
has classified the whole form of the whole poem as a satire.

Okot p'Bitek's theme is one of the alienation which occurs when individuals try to emulate the appearance of Western societies. This form is what some people call satire, others call it symbolism; this is achieved by means of a long sustained poem of 'search.' Lawino is the unwesternized village girl, as the critics would call her (many critics using the word 'village' may think that she's simple). She is actually an extremely complex woman compared with the stock definition of a village girl.4

Satire is also visible in song of Ocol, where Okot satirizes ill effects of Western education as well as the political ills in Africa. He uses Ocol skillfully as his mouthpiece. Okot plants words in Ocol, aimed at condemning himself and ridiculing politicians in general, without ocol's awareness. For example, through ocol as the politician Okot ridicules political injustices. Okot plants words in Ocol such that Ocol praises the luxurious and comfortable life he is leading. He also puts words in Ocol to speak for other politicians, that the masses owe them some sort of compensation because the politicians fought for the masses' freedom: Comrade, Do you not agree That without your present leaders Uhuru could never have come?

${ }^{4}$ David Rubadiri, "The Development of Writing in East Africa, " in Perspectives on African Literature, ed. Christopher Heywood (London: Heinemann Educational Books, 1971), p. 151. 


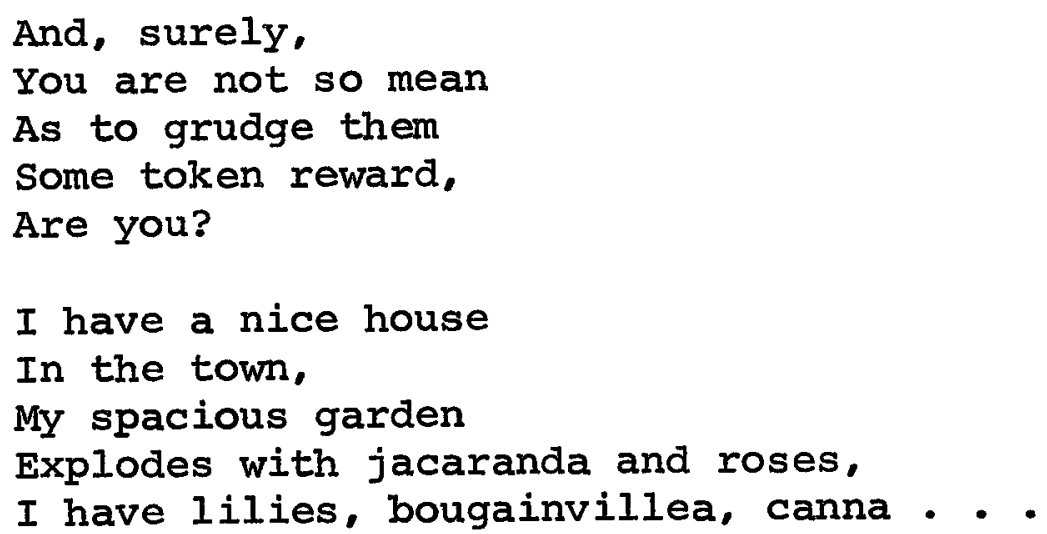

(Ocol 233)

Furthermore, Ocol as a politician notes that it is not his fault that the masses are poor. In this episode, by allowing ocol the politician to display the comfortable life Ocol is leading and his consequent ignorance of the poverty of the masses, Okot skillfully succeeds in having Ocol condemn himself without realizing it. However, at a deeper level okot is satirizing the political leaders in general; during their campaigns, they promise people a better life, but as soon as they are elected into office they forget their promises. Instead, they start leading a luxurious life at the expense of the suffering of the masses. Song of Malaya satirizes the hypocrisy of Africa's modern moralists who are against polygamy, prostitution and promiscuity. This kind of morality leads to Malaya's son being dubbed a bastard; it leads Malaya's brother to being ashamed of her prostitution. Therefore, Malaya's satire is aimed at attacking the accepted norms of moralists in Africa 
by exposing their hypocrisy. Consequently her satire is bitter in some instances, ironical and humorous in others. There are no satirical elements in Song of A Prisoner. In the rest of the 'songs,' we have seen that satire is used with the purpose to improve and hence it is essentially didactic. It is not just an expression of personal feeling but is aimed at challenging the African peoples to reconsider their values.

Humour beyond satire is used in all the "songs" except Song of A Prisoner. The effect of the usage of humour is that it makes the argument stronger and makes the drama vivid, interesting and realistic. Humour as used in the "songs" contributes to delight in the words themselves and hence contributes to the beauty of the poetry.

Humour in the "songs" is used on various levels. At one level it is used to strengthen an argument attacking the thought of the person or people whom the speaker is arguing against. For example, humour as well as truth is intended when the prostitute of Song of Malaya points out that Jesus was a bastard, since he was conceived out of wedlock. Humour here occurs because okot brings up an ironical point which is contrary to the global accepted norm of the Christian religion. It is a conventional judgment that 
Jesus Christ is the greatest son of God, and hence that he is Holy and came from Holy parentage. But when Okot portrays through different but logical reasoning that Jesus is a bastard, the reasoning is humorous because the conclusion is valid but incomplete.

Another example of how humour is used satirically to strengthen an argument in attack on the thought of an antagonist occurs when the prostitute silences her brother's hypocritical morality by revealing that she is aware that her brother has shared a bed with her friend next door. The irony of this situation is that her brother pretends to be moral and has a low opinion of the Malaya because of her prostitution.

Humour is further used to strengthen the argument of the mystery of the Christian myth of creation in song of Lawino. Lawino humourously questions:

When the Hunchback was not yet there Before he had moulded himself What things were there?

When skyland was not yet moulded And there was no earth, No stars No moon When chief Hunchback was not yet there Before he had moulded himself, Where did he get the clay For moulding things? 
The day for moulding himself

Where did he get it.

From the mouth of which river?

When the Hunchback was not yet there

And his head was not yet moulded

And his eyes

And his hands

And his legs

When his heart was not yet there,

How did he find

The clay for moulding things

Before he had any eyes?

The clay for moulding the Hunchback

Where was it dug from?

From the mouth of which river? (Lawino 138-139)

Humour is also used to strengthen arguments about be-

havior. For example, Lawino's exposure of white people's

immoral behavior in dances:

Women throw their arms

Around the necks of their partners

And put their cheeks

on the cheeks of their men.

Men hold the waists of the women

Tightly, tightly . . (Lawino 53)

Besides its uses to strengthen arguments, humour is

also used in the "songs" to strengthen the dramatic form, for example, in the protagonist's description of the enemy.

A good example is Lawino's description of her rival,

clementine.

Brother, when you see clementine:

The beautiful one aspires

To look like a white woman;

Her lips are red-hot

Like glowing charcoal, 
She resembles the wild cat That has dipped its mouth in blood, Her mouth is like raw yaws It looks like an open ulcer, Iike the mouth of a field! Tina dusts powder on her face And it looks so pale; She resembles the wizard Getting ready for the midnight dance.

She dusts the ash-dirt all over her face And when little sweat Begins to appear on her body She looks like the guinea fowl:

(Lawino 41-42)

Such a description not only makes the readers laugh, it also strengthens the argument that Africans who imitate whites blindly look ugly, and by this humorous presentation the dramatic form of the poem is strengthened.

Humour is also used to strengthen the dramatic form of the "song" in Lawino's description of hypocritical missionary teachers. "They have sharp eyes/For girls' full breasts"; (Lawino 122). In this case the dramatic form is strengthened by the funny portrait of the lecherous missionary. Furthermore, the humour underscores the falsity of Christianity by demonstrating the hypocrisy of its representative.

Humour is also used in exposing ironies of language. This is especially evidenced in Okot's literal translation of Acoli Christian words. For example, Okot refers to the 
"good word," "the clean book," the "clean ghost," "skyland," and "Hunchback." "Hunchback" literally refers to a person with a humpback, and here by the accident of the Acoli homonyms, it is used to refer to God or the creator of the universe. The word is therefore quite humorous. However, again its humorous quality supports the argument against the Christian myth of creation. Lawino does not see the possibility that God created himself, the world and everything in the world, especially since a hunchback is imperfectly formed and hence less than fully capable. Thus the myth has an omnipotent God creating himself imperfectly, and then, although crippled, creating our whole splendid universe. This seems impossible to Lawino. Even Okot's use of "skyland" instead of Heaven, "clean ghost" instead of Holy Ghost, the "clean book" instead of "the Bible," and "the good word" instead of biblical message, are not only humorous but they also show Okot's attitude toward Christianity. It is a false religion, hypocritical, exploitative and immoral, unworthy of such names as "clean." Song of A Prisoner and Song of Ocol are special cases. Song of A Prisoner expresses its bitter criticism of post-independent political life through a dramatic speaker and situation whose pathos excludes all possible humour. 
From which I came Reflected in them

(ocol 215)

The stanza above is not only humorous but didactic, to the extent that it conveys self-hatred of the brainwashed black elite. Okot's argument against ocol is that he blindly follows Western ways which have taught him self-hatred. The irony of the situation is that Ocol does not realize what Okot is having him say against himself, but the readers are aware of it. Similarly when 0col says:

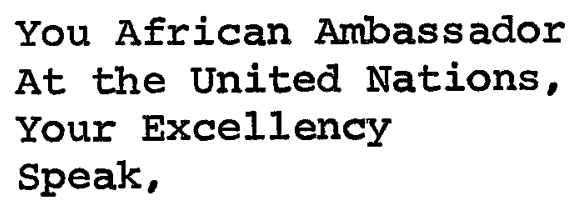

Tell the world

In English or in French

Talk about

The African foundation

On which we are

Building the new nations

of Africa.

(Ocol 252)

Ocol is fully aware of one humorous irony here; those who preach in defense of African foundations ought to do their preaching in African languages. But another irony of the situation is that Ocol is educated and is speaking English as Lawino told us. Without realizing it, Ocol is condemning himself when he condemns the people who speak English. Thus, a special achievement in ocol is the way we share Ocol's humour and at the same time have a laugh at him. 
In conclusion, about humour one can say that okot skillfully uses it in the three "songs" to excite amusement in the readers, to awaken and direct their scorn for untruth, pretension and hypocrisy, and generally to reflect the incongruity of life itself.

Imagery is another major technique utilized by okot to portray his ideas. No doubt, Okot utilizes rich imagery in his four "songs." Okot's imagery in certain places comes from what he has known, seen, and felt in his life experience. Okot's imagery employed in the "songs" ranges from the simplest similes to the most complex metaphors. Whether simple or complex, all the imagery used enriches the subject by the way it makes the comparison seem inevitable. Through imagery the deeply hidden meanings of the ideas are revealed. Besides adding clarity to the meaning, imagery also makes the meaning more forceful. For example, images of animals, insects and plants are very frequent in Song of A Prisoner, which piles up pictures of destruction of human and animal life on top of one another to convey the impression of a whole society trapped in a prison of mutual violence. 5

${ }^{5}$ For a detailed discussion of this matter, see Edward Blishen. Introduction to Song of A Prisoner (New York: Joseph Okpaku Publishing Co., 1971), pp. 33-34. 
Some of the images are taken from Acoli songs. For example, Song of Lawino draws much of its imagery from Acoli life and literature. Often Lawino refers to proverbs which are rich in imagery. For example, the particularly crucial proverb: The pumpkin in the old homestead Must not be uprooted: (Lawino 49)

which is used to warn ocol not to abandon his culture needlessly.

Song of Lawino has countless similes. Two examples may suffice. To describe the rage of her husband towards her, Lawino says:

When I pass past my husband He hisses like the wounded ororo Snake. (Lawino 70)

The effect of such a simile is that it deepens the reader's awareness of Ocol's contempt for Lawino. In describing the cooking equipment, she says, they have:

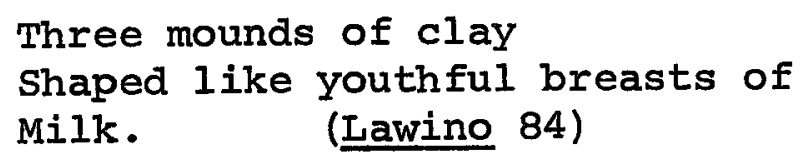

and by so doing she paints a clear picture of how they look. The metaphors Lawino borrows from her culture convey Lawino's feelings much more fully than her own words. Many such metaphors are from Acoli songs. For example, sorrow names are used to express sadness very clearly in the Acoli community . 
Some names are names of sorrows.

Alobo, Abur, Ayiko, Woko

That fate has thrown

A large basket

To be filled

With dead children. (Lawino 126)

Metaphors and similes together are used by Lawino in a vividly descriptional way. For example:

You kiss her open sore lips

As white people do

And the lips of the men become bloody

with blood dripping from the red-hot

lips.

Their teeth look

As if they have been boxed in the mouth.

(Lowino 53)

The above quotation is a combination of metaphor and simile, intertwined to convey Lawino's disgust at white people's use of lipstick. In general there are more similes than metaphors in Song of Lawino because metaphors are figures of speech rich in meaning but sometimes obscure. More than the other songs, Lawino presents intricate, extended arguments and syllogistic reasoning. Metaphors tend to obscure such presentations, whereas similes make such arguments clearer. Perhaps this explains the predominance of similes in Lawino. The same obscurity or indirection of metaphor is convenient for treating the sensitive issue of sex in song of Malaya. There Okot appropriately utilizes metaphors which 
are more acceptable precisely because they do not hit the nail on the head:

And you bush teacher

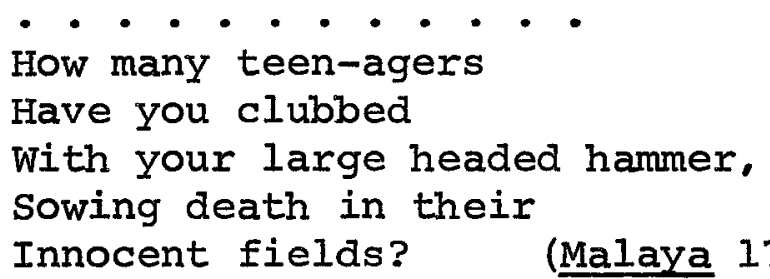

Another example of metaphor in Malaya is:

What better proof

Of manhood?

Especially when the wife

In the house

Eats lizard eggs

To prevent pregnancy! (Malaya 150)

"Eat lizard's eggs" is a perfect metaphor here, referring of course to swallowing pills or contraception to avoid gestation.

On the other hand, Song of a Prisoner makes heavy use of striking animal images which do hit the nail on the head in conveying the dehumanized experience of the oppressed. For example, the image of a dog is used appropriately to describe the chief's isolation from his society, because when people want to alienate themselves from other people they use a dog, a fierce but obedient animal, as a means of protection. One example occurs when the prisoner describes his imagination of the "Big Chief" breaking in his home to rape his wife. The description is cinematic 
because the readers can feel and imagine the "Big Chief" going to the prisoner's house. The picture created is very real and hence it contributes to the dramatic structure of the poem.

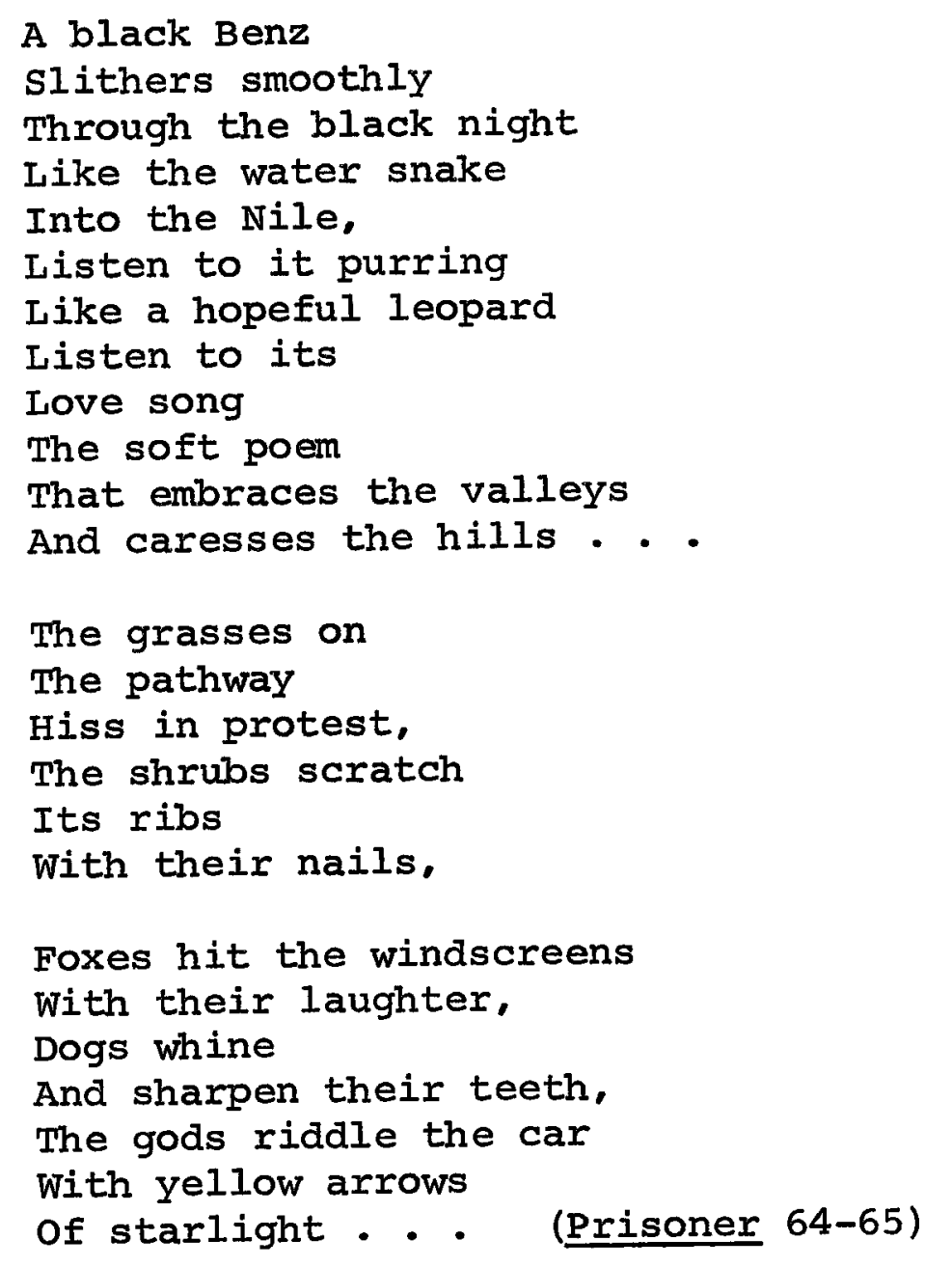

In this passage not only is the Benz transformed into personified animals, but also grass, shrubs and gods are personified. The result is utterly clear and utterly expressive. Bahadur Tejani has described the power of Prisoner's imagery thus: 
But the poet's style and rich imagery expresses the contrast between the haves and have nots in an entirely new manner. Implicit in the lines is the ruthless mercenary power of the politician, his quiet hunting style, his capacity for sacrilege. As the exploiter's finger's reach the very centre of his life, the prisoner demands words that have the terror of the French guillotine. 6

Here, of course, Tejani refers to the tense prisoner's frustration and what he thinks his solution should be. As the prisoner puts it:

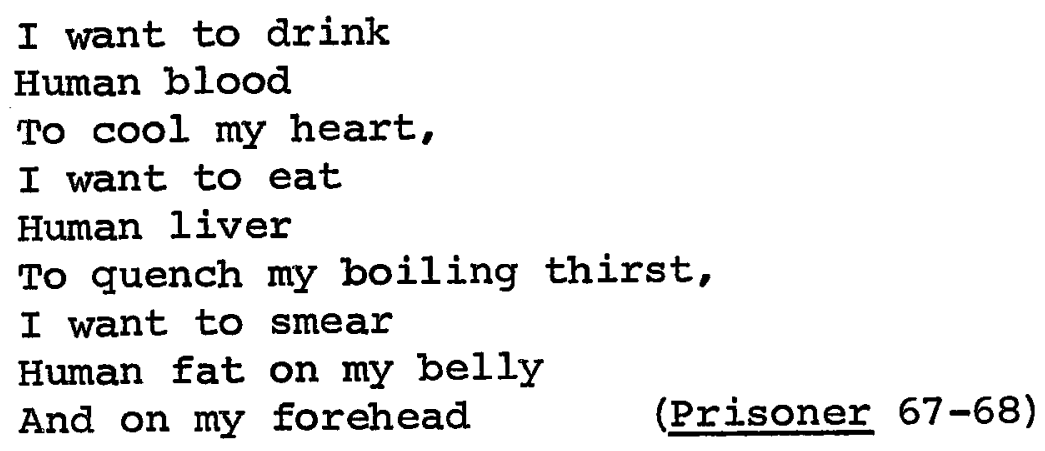

In this passage the prisoner resorts to extreme metaphors to express his anger and desire for vengeance. One particular strength in the choice of imagery is that it uses a metaphorical hunger and thirst to speak about his family's literal hunger and thirst.

This incomplete scan of Okot's imagery demonstrates Okot's special skill in the use of imagery, both as a support to his argumentation and as an aid to his dramatization.

6 Bahadar Tejani, "Okot p'Bitek," in African Literature Today, ed. Eldred Durosimi Jones (New York: Africana Publishing Co.. 1973), p. 162. 
Finally, it is necessary to say a word about okot's prosody. Prosody literally means the science of versification. Because the songs are poetry, of course the rhythm is important. One notices a development from song of Lawino to later poems. ${ }^{7}$ The lines in Song of Lawino are longer than the lines in the rest of the songs. They vary between about eight and thirteen syllables in different parts of the poem and are most commonly about nine or ten syllables. Unlike longer lines in Song of Lawino, the basic line in Okot's later poems is of four to six syllables and very short lines are the commonest.

Irregular free verse is used in song of Lawino. In her description of "How aged modern women pretend to be young girls!" (Lawino 44$)$, Lawino says:

They mould the tips of the cotton Nets So that they are sharp And with these they prick The chests of their men! (Lawino 44)

Or in her description of Ocol's bragging she says:

He just shouts

Like house flies

Settling on top of excrement When disturbed. (Lawino 62)

${ }^{7}$ For a detailed discussion of this matter, see G. A. Heron, The Poetry of Okot p'Bitek (New York: Africana Publishing Co., 1976), pp. 30-31. 
On the contrary, Song of Ocol is marked by the "English free verse." There is a consistent stress pattern in Song of Ocol. Shorter lines are employed to produce a rhythm that is very effective in emphasising the point. For example:

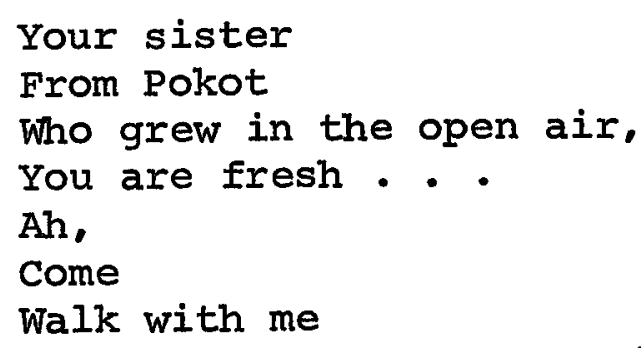

Perhaps there is a correlation between the change in length of the lines and in the sentence structure. As said earlier, Lawino typically uses more complicated sentences. For example, contrast these two paragraphs. Lawino in her description of the conflict between her husband and his brother, says of ocol:

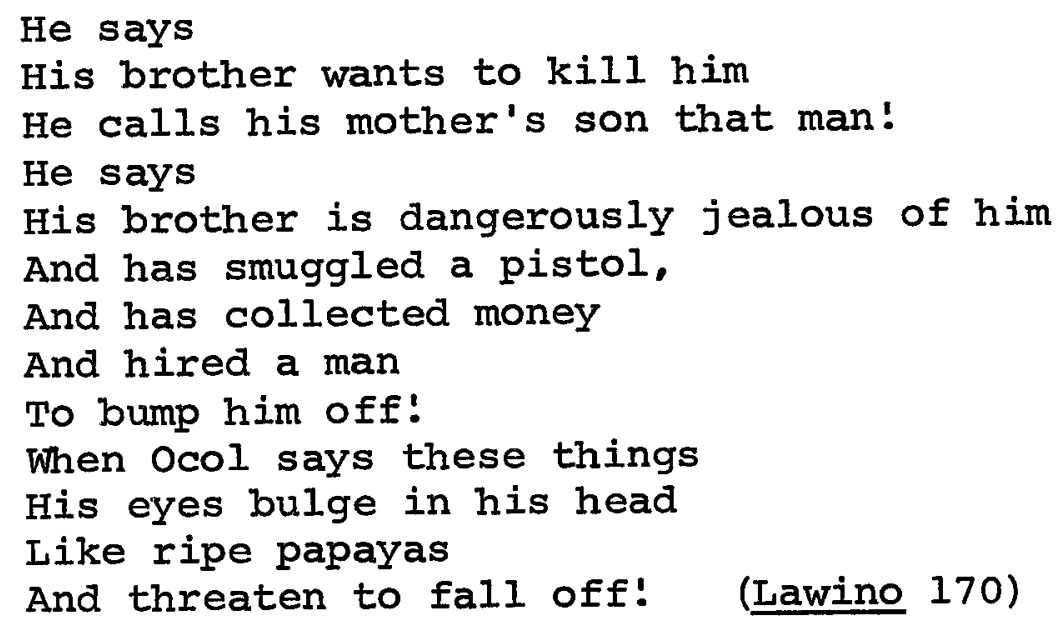


Karibu, come in, Enter. . .

All my thanks

To you

Schoolboy lover,

I charge you

No fee...

That shy smile

on your face,

And . .

Oh:

I feel ten years

Younger. . . (Malaya 129-130)

Nevertheless, all the "songs" use lines which end with grammatical units such as a noun plus prenominal modifiers, a noun plus all its modifiers, a verb plus its objects, a clause, a prepositional phrase and so forth.

This technique allows two effects. One effect is clarity, with emphasis on each unit of thought or image. The second effect is rhythm which closely imitates oral delivery. Thus prosody, too, is manipulated to reinforce both the meaning and drama.

In conclusion, one can say with confidence that ocol combines powerful techniques with serious thought to produce marvelous poetry. As Edward Blishen says in his introduction to Song of A Prisoner:

He [Okot] is a master of writing for the human voice. . . (Prisoner 40) 
Or as Maina Gathungu says:

- . Seriously, Okot has behaved just like any good student of law, social anthropology and education and like a skilled player--which he is. He even ventures into politics . . He endeavours to enlighten the world on his community. He then tries to justify the ethics and right to exist of his community, and finally, portrays this community as made of people who have feelings, passions, love, hate, aspirations, values and goals. His community widens until his gyre changes from a simple home of man and wife, through the Acoli community, the Ugandans, the Africans and then to mankind.

8 Maina Gathungu, "Okot p'Bitek: Writer, Singer or Culturizer," in Standpoints on African Literature, ed. Chris Wanjala (Nairobi: East African Literature Bureau, 1973), p. 52 . 
CHAPTER V

\section{SUMMARY AND CONCLUSION}

Ultimately, one can safely say that okot's importance, popularity and influence in East Africa and outside East Africa, lie in the significance of his themes and the powerful, original manner in which he presents them.

The themes okot portrays centre around his thought on East Africa's past, present and future, social, economic and political situations. He deals with important subjects reflecting the common thoughts and experiences of real people. For example, in Song of Lawino and Ocol, he portrays real African people undergoing and reacting to European influence. Some like Lawino stop to think and to question the validity of hating their own culture and blindly emulating Western culture. Others like Ocol who have been brainwashed in the missionary schools simply abandon their culture in preference for the Western culture, without reasoning why they should do so. In fact the realism of this situation is evidenced in the fact that Lawino and ocol have become common household 
words in East Africa. Some people will condemn the "Lawino's" for their "conservatism" and praise the "Ocol's" for their "modernity" and vice versa.

One example of the subjects which reflect the common thoughts and experiences of real people is conflict of values as portrayed in Song of Lawino and Song of Ocol. Through Lawino, Okot reasserts the values which existed before the coming of Europeans in East Africa. On the other hand, he reveals the falsity of Western society's claim to be better or more genuine than African society, especially the claims of Christianity. Through Ocol, Okot portrays the harmful effects of Western values, specifically in East Africa, but generally in Africa as a whole. One of the harmful effects of Western education/values is alienation and self-hatred. Ocol, denies his Africanness. He hates his continent, his community and even, in a sense, himself. He is ashamed of his colour, "blackness." He therefore thinks that all Acoli ways of dress, dance, religion and medicine are nasty, and backward and must be replaced. On the contrary, Lawino expresses the healthiness of Acoli culture, and she exposes the immorality and hypocrisy of Western ways of life, especially, Christianity.

After Song of Lawino and Ocol (1966), Okot moves from 
the conflict of Western values versus traditional values, to post independent stresses. In Song of A Prisoner (1971), he develops the political theme which he had started discussing in Song of ocol. He criticizes the fact that the hopes of freedom (uhuru) have been betrayed by the post independent African political leaders. Consequent to the political injustice they have created, their subjects/citizens are suffering from deprivation. Disease, hunger, poverty, and unemployment are cited among the problems the African people are encountering in newly independent African societies. Okot also discusses the problem of tribalism, as one of the biggest current problems in most of the African countries.

In Song of Malaya, Okot deals with moral issues. He specifically exposes false sexual morality by conveying the hypocrisy of modern moralists, and by indicating that promiscuity and prostitution are inevitable in society. In any case, he argues that they are no accident, but they are as old as the history of man himself. Finally, by ironical implication, he suggests that such modern moralists should reexamine the moral ideas from which they work.

The themes would not be as successfully conveyed without Okot's special way of presenting them. By his independence from Western forms of style, and hence by his 
creative imagination, Okot has originated a style in which he uses English merely as a tool to reach his audience, without necessarily emulating the Western usage of such elements as imagery or figurative language. Instead, Okot uses images, symbols, "songs" and proverbs taken from Acoli oral 1iterature. The significance of Okot's use of African images in his poems is that the meaning of African ideas is most effectively expressed when African forms of expression are retained. Okot also employs a thematic organization to enhance effective communication of his ideas. His use of detailed arguments, arranged in thematic sequences gives logical force to the meaning or central thought portrayed. Each poem is divided into a certain number of sections, each of which has a title corresponding to its contents; each section deals with a specific theme.

Okot skillfully portrays these themes through a dramatic structure which gives emotional force to the poems. Each of the four "songs" is a dramatic monologue. This form enables the speaker to address various different individuals and/or social groups, commenting on various social, economic and political ills in African countries. Consequently, it is through a character's statements that the major didactic themes are revealed. Therefore the personality of his speaker 
and the personality of persons spoken to or about become important elements in the overall design of the poems. For example, Lawino is knowledgeable of all ways of life in her society. According to the Acoli standards, she is beautiful, educated and, in brief, a paragon of her own society. We are led to admire her, and, by so doing, we develop an appreciation for the inherent strength and structure of traditional society. In contrast, by creating the character of ocol to be rude, arrogant, abusive and irrational, Okot does not allow us to respect him. Instead we are led to understand that the African elite who blindly emulate the Western ways are oblivious to the values of their own culture. They carry on slavish, irrational imitation of white men's ways. Similarly, in portraying the minor character clementine, in Song of Lawino, a Westernised black woman but pitiable and sickly in her looks, Okot assures that we will not respect her. Consequently we are not allowed to admire what she stands for, that is, ideal beauty in Western eyes. Similarly, in Song of A Prisoner in creating a prisoner who is angry and full of hatred, the author is able to portray the despair, fury and anger fiercely expressed by many people everywhere who are politically in chains. Also by presenting a composite of prisoners with different 
biographies, Okot is able to comment on society's ills in a holistic manner rather than through a single individual biography. By giving the prisoner a sense of pride and dignity in himself, Okot enables the reader to see the peoples of Africa determined to live on irrespective of the problems they are facing.

In Song of Malaya, the Malaya, who is the protagonist, has a very admirable character. Like most prostitutes in literature, this one has tempting and admirable qualities. Her statements show how valuable, amiable and attractive she is, and by implication how good prostitutes in general can be. Her arguments also lead us to conclude that prostitution is inevitable, at least in certain social circumstances. She is very knowledgeable of men's ways and movements. For example, she knows many people who have committed adultery and/or promiscuity, such as those cited in the old Testament; the Egyptian girls, "Raha's/with her two spy boyfriends," "Magdalene who anointed/The feet of Jesus!" and "Theodora/The queen of whores." She is knowledgeable enough to know that Jesus Christ, the founder of Christianity, was a bastard. She also knows that the "bush teacher," who calls her child a bastard, has bastards himself. Besides, she is knowledgeable enough to have facts about her brother's immorality. She 
exposes his immorality when he tries to comment on her "immorality"; she reveals that she knows he recently shared a bed with her friend next door. In this way, hypocrisy of the so-called moralists is exposed. Through her characterization as an adept thinker, okot is able to explore the essence of guilt and shame that the so-called moralists keep advocating. Consequently, through the Malaya, Okot is able to make a forceful claim that prostitution and promiscuity are inevitable in society.

Similarly the characterization of minor characters such as that of the "black Bishop," the "bush teacher" and the prostitute's brother help to expose hypocrisy of the so-called moralists. For example, the "black Bishop" is presented as hypocritical. He is a bastard, "his father had six wives; his mother was not one of them," and yet his preaching aims at restraining "other men's daughters/To a sexless life/Like nuns."

Closely linked to characterization is the use of vignettes and/or sustained plot in the poems. By vignettes we mean types of short scenes, with sketched plot and character, which in okot's poems are distinguished by their delicacy of portraiture. Vignettes are employed by okot in the poems to add meaning vividly and to reinforce the dramatic 
structure of the poems. For instance, in Song of Malaya, one of the vignettes is that of mother Malaya waiting for the return of her child from school. When she learns that he has been called a bastard, she consoles him by raising intelligent, fundamental points about morality. First, she exposes the hypocrisy of the bush teacher, a man who has called her child a bastard and yet is himself a maker of bastards :

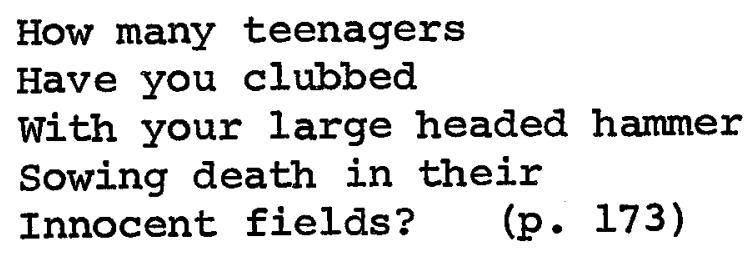

secondly, she notes an irony of Christianity. The "greatest man that ever lived," (p. 173) Jesus Christ, the "Saviour," "Redeemer" and, in brief, founder of Christianity, was also a bastard. By ironical implication, Okot is challenging modern moralists to reexamine the principles on which they base their moral values. For if they base them on Christianity, then there is an inconsistency. Therefore, using one vignette, okot is able to make three fundamental didactic points on sexual morality. This is just an example of the short scenes he uses and the aims he achieves through them. There are many vignettes in all the poems which are not enumerated here, but the point is that in all of them, okot 
uses vignettes to portray the didactic themes of the poem. The plot of each poem is achieved through the conscious arrangement of each vignette's events, especially in Song of Lawino. Song of Lawino has the most integrated plot. The reader is able to know the past and present relationship of Lawino and Ocol. In Song of Ocol, however, the author works with the plot already in progress. The rest of the poem does little to supply facts about the protagonist's history. In Song of A Prisoner there are two histories and therefore two biographies, which are nonetheless blended together because of the concentration on one single situation, the prison situation. In Song of Malaya, there is no single plot, but there are different little scenes, which are united by their protagonist and their exposure of false sexual morality. In all cases, plot gives unity, form and purpose to each poem. In each case full plot is not only dependent upon vignettes, but it is also based on the characters and the situation surrounding the characters. In this way, Okot portrays the didactic themes in the "songs."

Humour and satire are used in all the songs except in Song of A Prisoner. The pathetic situation of Song of A Prisoner accounts for this difference. In Song of Lawino, Lawino satirizes Ocol's ugly behaviors owing to his blind 
emulation of Western ways. She also satirizes the Christian religion and the immorality and hypocrisy of missionaries. Her satire is aimed at ridiculing ocol, throughout the poem, for his negative attitude towards his "roots" in African values. She verbally attacks Ocol, who used to admire her but now has abandoned her in preference for clementine. Satire is also visible in Song of Ocol. The author satirizes ill effects of Western education as well as the political ills in Africa. He does this by planting words in the Westernized protagonist, Ocol, who condemns himself and his counterparts without realizing it.

In Song of Malaya, the Malaya satirizes the hypocrisy of Africa's modern moralists who are against polygamy, prostitution and promiscuity. She succeeds in her satire by exposing the hypocrisy of such moralists.

Other humour is also used in all the "songs" except for Song of A Prisoner. It is used in the three "songs" not only to strengthen the argument but to make the drama vivid, interesting and realistic. It is also used to strengthen the arguments about behavior, as well as to expose ironies of language. Okot skillfully uses humour in the three "songs" not only to excite amusement in the readers, but to awaken and direct their scorn for untruth, pretension, 


\section{3}

hypocrisy and in general to reflect the incompatibleness of life itself.

For instance, Song of Malaya is satirical and humorous in nature. A lot of humour accompanies the many vignettes presented. The effect is that it awakens in the readers scorn for untruth and pretensions as well as a tenderness and admiration for the prostitutes, who are ridiculed by hypocrites. The prostitute is not only intelligent but humourous as well. For example, in her description of those who fulfill their needs through the prostitutes, she says:

Black students Arriving in Rome, In London, in New York . . Arrows ready, bows drawn For the first white kill. . . (p. 153)

While this kind of humour excites amusement in the readers, through it the author is able to make the didactic point that this prostitute is a healthy person in society.

In general the language used in all the poems further enables the author to convey the didactic points to his readers in a skillful manner.

One of the aspects of language used is imagery. In Song of Lawino, images used are taken from Acoli oral literature. They add flavor and richness to the poem, and enable 
the author to portray African ideas without their distortion. One example is the image in the proverb central to the whole poem viz:

The pumpkin in the old homestead

Must not be uprooted. (p. 153)

Through this image above, Lawino succeeds in portraying the fact that she is not asking Ocol to cling to all traditional values, but rather that she is asking ocol not to destroy Acoli values for the mere sake of destroying them. Similarly, in Song of Ocol, Okot draws some imagery from oral literature and he draws other from current daily experiences.

In Song of A Prisoner, images take the reference to insects, animals and vegetable life. Reference to nature in general is what is applied. Sometimes, images are taken from his ordinary daily experiences, for example, experience in athletics. To vividly describe the pain in the prisoner's stomach owing to his hunger he says:

$$
\begin{aligned}
& \text { olympic athletes throw javelins } \\
& \text { Inside my belly. (p. 51) }
\end{aligned}
$$

Such images add meaning and force to the poem. They also lead to the economy of words used in the poem. In Song of Malaya, metaphors are especially used in describing the more sensitive issues of sex. On the other hand, many similes are used in Song of Lawino in order to portray the complexity of 
its many themes.

For easy understanding of the poems, Okot utilizes simple words and grammar and plain rhythm in all the "songs." Furthermore, he employs rhetorical devices of apostrophe, anaphora, alliteration and repetition. All are used to secure an effect of forcefulness and persuasiveness about the issues discussed. For example, through apostrophe, Okot establishes the roles of characters, and sets up the atmosphere of debate; through it, the readers are helped to judge from the arguments of the protagonist what they think is good or bad.

Consequently, one can safely say that the techniques of Okot p'Bitek are a compelling form for the statement of very precisely argued facts and values in the "songs." The value of this combination of important subjects forcefully argued with dramatic presentation can be seen by his place in East African literature. Okot has been one of the most praised, most discussed, studied, read and respected East African poets. He is East Africa's most often read poet, perhaps most often read author, specifically in East Africa, and generally in Africa, Britain, United States of America and other places of the world. His original style has had great influence on many East African literary writers. As a 
result, he has many imitators such as Okello Oculi, Taban Lo Liyong, Joseph Buruga and Everett Standa, to name but a few. He is the most influential writer, actually influencing political and cultural policies in his home government. The creative literature of okot p'Bitek thus stands as an outstanding example of great art performing a truly important social service. 


\section{BIBLIOGRAPHY}

\section{Primary sources}

(Asterisked items were not available for use in this thesis.)

p'Bitek, okot. Song of Lawino and Song of ocol. Combined School Edition. Nairobi: East African Publishing House, 1972 .

- Two Songs: Song of Malaya and Song of A Prisoner. Nairobi: East African Publishing House, 1971. - Song of A Prisoner. With an Introduction by Edward Blishen. New York: Joseph Okpaku Publishing Co.. Inc., 1971 .

- Africa' Cultural Revolution. Nairobi: Macmillan Books for Africa, 1973. *

- African Religions in Western Scholarship. Nairobi: East African Iiterature Bureau, 1971.

- Religions of the Central Luo. Nairobi: East African Literature Bureau, 1971.

- The Horn of My Love. London: Richard Clay Press, 1974 .

- The Hare and the Hornbil1. London: Heinemann Educational Books, 1978.

"Reflect, Reject, Recreate." In East African Journal (April 1972). * 
- Oral Literature and Its Social Background Among the Acoli and Lango. B. Litt. Thesis, University of Oxford, 1964 .

- "Order of the Black Cross." In Journal of the New African Literature and the Arts (WinterSpring 1971).

- "Indigenous ills." Transition: A Journal of the Arts, Culture and Society 7:32 (August-September 1967) : 47 .

- Lak Tar. Kampala: The Eagle Press, 1953.

- "Essay." In East Africa's Past and Present. Edited by B. A. Ogot. Paris: Presence Africaine, 1971. *

\section{Secondary Sources}

Books

Cook, David. African Literature: A Critical Review. London: Longman Group Press, 1977.

Darthorne, O. R. The Black Mind: A History of African Literature. Minneapolis : University of Minnesota Press, 1974.

Herdeck, Donald E. African Authors: A Companion to Black African Writing, 1300-1973. Washington, D.C.: Black Orpheus Press, 1973.

Heron, G. A. The Poetry of p'Bitek. London: Cox and Wyman, Ltd., 1976.

Killam, G. D., ed. African Writers on African Writing. London: Heinemann Educational Books, 1973.

Mutiso, G. C. M. Socio-Political Thought in African Literature: Weusi? United Kingdom: The Macmillan Press, 1974 .

Nazareth, Peter. An African View of Literature. Evanston, I11.: Northwestern University Press, 1974. 
Roscoe, Adrian. Uhuru's Fire. London: Cambridge University Press, 1977 .

Thiong'o, Ngugi wa. Homecoming. New York: Laurence Hill Co., Press, 1972 .

- Petals of Blood. New York: E. P. Dutton Publishing Company, 1978 .

Wright, Edgar. The Critical Evaluation of African Literature. London: Heinemann Educational Books, 1973.

\section{Articles}

Atieno-odhiambo, Aloo Ojuka, Margaret Marshment, and George Heron. "Okot and Two Songs: A Discussion." In Standpoints on African Literature: A Critical Anthology. Edited by Chris Wanjala. Nairobi: East African Literature Bureau, 1973.

Gathungu, Maina. "Okot p'Bitek: Writer, Singer or Culturizer?" In Standpoints on African Literature: A Critical Anthology. Edited by Chris Wanjala. Nairobi: East Africa Literature Bureau, 1973.

Pickford, Tim. "Horn of My Love: A Review." In African Literatures-Some Notes d. by Jan Knappert. Hamilton, New Zealand! Outrigger Publishers, 1975.

Rubadiri, David. "The Development of Writing in East Africa." In Perspectives on African Literature. Edited by Christopher Heywood. Ibadan: University of Ife Press, 1971 .

Tejani, Bahadur. "Okot p'Bitek." In African Literature Today. Vol. 7 Edited by Eldred Durosimi Jones. New York: African Publishing Company, 1973.

Ward, Michael R. "Okot p'Bitek and the Rise of East African Writing." In A Celebration of Black and African Writing. Editors B. King and K. Ogunbesan. Zaria: Oxford University Press, 1975. 